Florida International University FIU Digital Commons

\title{
Balance of Power in Regional Institutional Framework: Reassessment of the China-U.S.-Japan Trilateral Relationship
}

Yuanyuan Fang

yfang004@fiu.edu

DOI: 10.25148 /etd.FIDC001987

Follow this and additional works at: https://digitalcommons.fiu.edu/etd

Part of the International Relations Commons

\section{Recommended Citation}

Fang, Yuanyuan, "Balance of Power in Regional Institutional Framework: Reassessment of the China-U.S.-Japan Trilateral Relationship" (2017). FIU Electronic Theses and Dissertations. 3386.

https://digitalcommons.fiu.edu/etd/3386 


\title{
FLORIDA INTERNATIONAL UNIVERSITY
}

\author{
Miami, Florida
}

BALANCE OF POWER IN REGIONAL INSTITUTIONAL FRAMEWORK: REASSESSMENT OF THE CHINA-U.S.-JAPAN TRILATERAL RELATIONSHIP

A dissertation submitted in partial fulfillment of

the requirements for the degree of

DOCTOR OF PHILOSOPHY

in

INTERNATIONAL RELATIONS

by

YuanYuan Fang

2017 
To: Dean John F. Stack, Jr.

Green School of International and Public Affairs

This dissertation, written by Yuanyuan Fang, and entitled Balance of Power in Regional Institutional Framework: Reassessment of the China.-U.S.-Japan Trilateral Relationship, having been approved in respect to style and intellectual content, is referred to you for judgment.

We have read this dissertation and recommend that it be approved.

$\begin{array}{r}\hline \text { Ronald W. Cox } \\ \hline \text { Jin (Julie) Zeng } \\ \hline \text { Sukumar Ganapati } \\ \hline \text { Thomas A. Breslin, Major Professor }\end{array}$

Date of Defense: June 30, 2017

The dissertation of Yuanyuan Fang is approved.

Dean John F. Stack, Jr. Green School of International and Public Affairs

Andrés G. Gil Vice President for Research and Economic Development and Dean of the University Graduate School

Florida International University, 2017 


\section{DEDICATION}

I dedicate this dissertation to my beloved mom, who inspired me to take this journey and devoted herself to raising me to be a wise and successful woman, to my husband, who has always encouraged me, no matter how difficult the journey became, to my father, who has always supported me, and to my son, Ethan. 


\section{ACKNOWLEDGMENTS}

I would like to thank my major advisor, Dr. Thomas A. Breslin for his exceptional dedication to guide me through the course of $\mathrm{PhD}$ study and help me be the best possible scholar. Dr. Breslin is a great mentor who not only constantly checked on my progress but also made an extra effort to make sure that I could finish and helped my family and me when things were difficult. Dr. Julie (Jin) Zeng's advice and help have been a constant supportive presence. Dr. Ronald W. Cox's critical perspective helped hone my focus. Dr. Sukumar Ganapati's perspective from public administration helped me research the topic from an institution perspective.

I would also like to thank the Florida International University Department of Politics and International Relations (PIR) faculty for providing an excellent education and being supportive of graduate students. Dr. Shlomi Dinar, Dr. Rebecca Salokar, Dr. Susanne Zwingel and Dr. Harry Gould were extremely informative and caring. I am grateful for their support for my study and assistance in helping me secure financial support. The professors I worked with for my teaching assistantships have been supportive of my study and taught me various teaching methods: Dr. Thomas A. Breslin, Dr. Julie (Jin) Zeng, Dr. Felix Martin, and Dr. Marcie Washington. I am grateful for my professors during my graduate career: Dr. Thomas A. Breslin, Dr. Paul Kowert, Dr. Harry Gould, Dr. Julie (Jin) Zeng, Dr. Mohiaddin Mesbahi, Dr. Ronald W. Cox, Dr. John Clark, Dr. Felix Martin, who helped me establish a knowledge foundation and equipped me with research skills for my dissertation research. The PIR staff, including Maria Elena Gil, Maria Wilkinson-Diaz, Martha Rodrigues, and Kimberly Noy were very helpful. I am also grateful to my fellow 
PhD students, Bibek Chand, Zenel Garcia, Nicolas Terradas, Lukas Danner, Onur Erpul, Nicolas Beckmann, and Ryan Opsal for their encouragement and support of my dissertation writing. 


\section{ABSTRACT OF THE DISSERTATION}

BALANCE OF POWER IN REGIONAL INSTITUTIONAL FRAMEWORK: REASSESSMENT OF THE CHINA-U.S.-JAPAN TRILATERAL RELATIONSHIP. by

Yuanyuan Fang

Florida International University, 2017

Miami, Florida

Professor Thomas A. Breslin, Major Professor

Relations among China, the United States, and Japan constitute some of the most complicated and dynamic relations in the contemporary era. Since the end of the second half of the twentieth century, all three nations, which were not in favor of regional multilateralism, have changed their strategy and have actively engaged in regional AsiaPacific institutions. This research attempts to integrate realist discourse on the balance of power and liberal analysis of institutions to look at the China-U.S.-Japan interactions within regional institutions. This study explores why China, the United States, and Japan have increased their cooperative interaction in regional institutions in the Asia-Pacific region, despite having divergent interests and different visions of the future regional power structure. 
By searching and analyzing archives documenting China-U.S.-Japan regional policies and policies directed at regional institutions and observing in detail China- U.S.Japan interactions within Asia Pacific Economic Cooperation (APEC), this dissertation argues that institutional balancing provides a framework that helps identify countries' overlooked intention to check and balance targeted powers in regional institutions. Regional institutions not only provide an opportunity for participant countries to discover and address common interests but also provide an opportunity for participant countries to lobby for their own interests and to balance the gains and influences of the other powers. This dissertation explores conditions under which institutional balancing is an optimal choice for countries and notes key methods: controlling membership; shaping institutional norms, rules, and mechanisms; and pursuing balanced alliances that have been practiced by China, the United States, and Japan in regional institutions in the Asia-Pacific region. 


\section{TABLE OF CONTENTS}

CHAPTER

PAGE

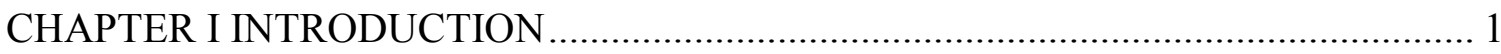

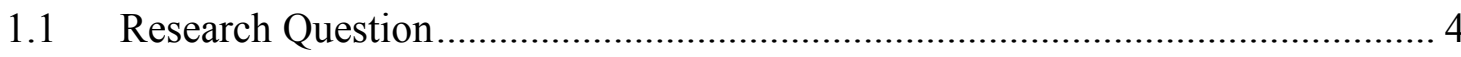

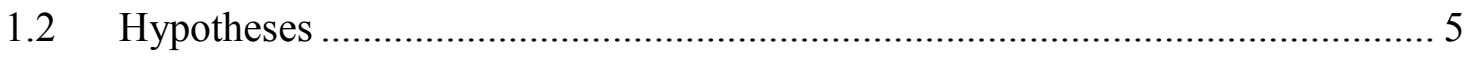

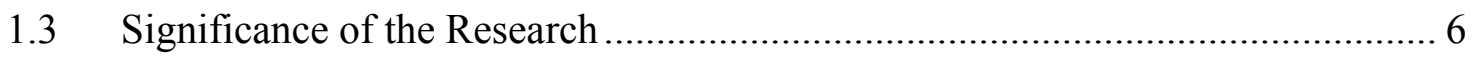

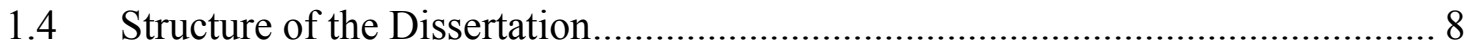

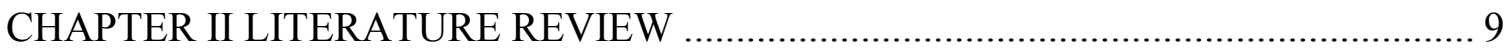

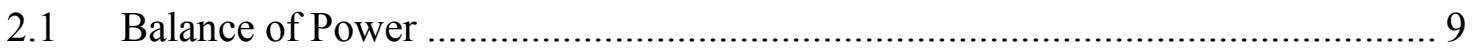

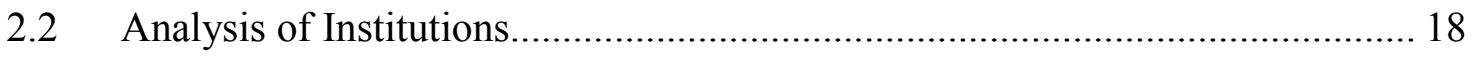

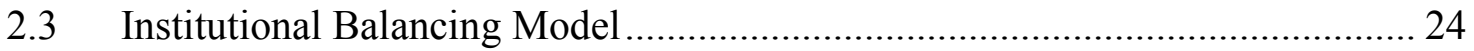

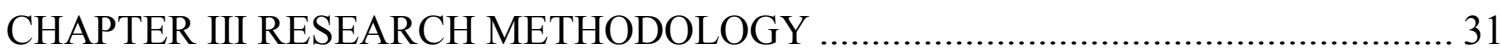

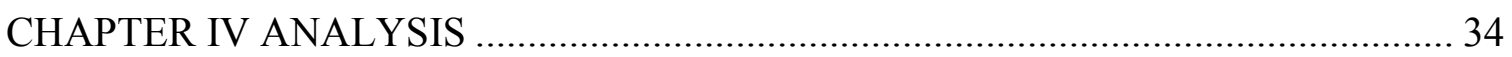

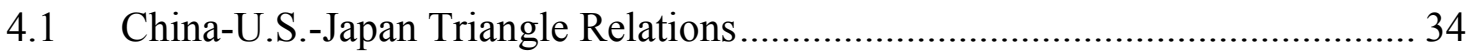

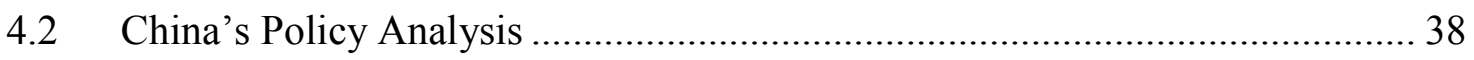

4.2.1 The origin and development of China's regional policy ................................. 38

4.2.2 China's foreign policy towards regional institutions in Asia Pacific ............... 49

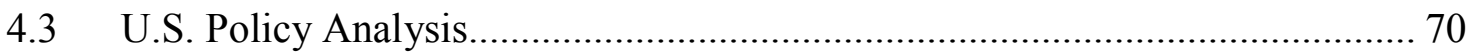

4.3.1. U.S. policy towards the Asia Pacific ............................................................. 71

4.3.2. U.S. Foreign policy towards regional institutions in Asia Pacific................... 85

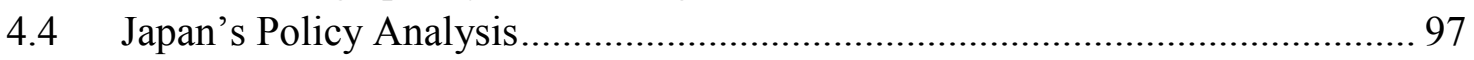

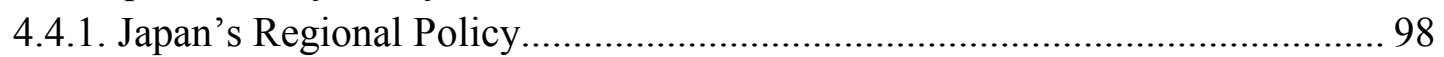

4.4.2. Japan's policy towards regional institutions................................................. 110 


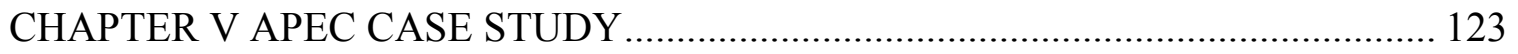

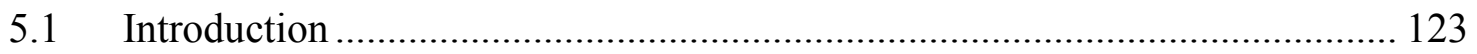

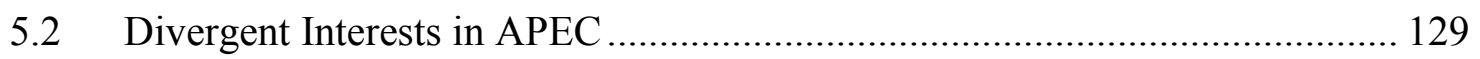

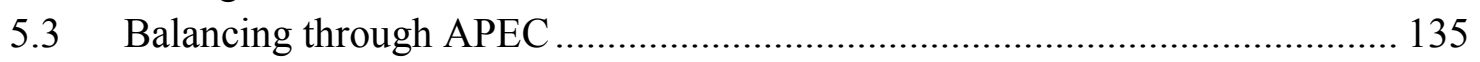

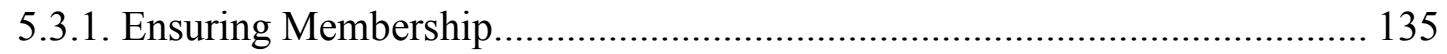

5.3.2. Shaping APEC's Norm, Rules and Mechanism ........................................ 138

5.3.3. Pursuing Balancing Alliances............................................................... 143

CHAPTER VI FINDINGS AND CONCLUSION ................................................. 147

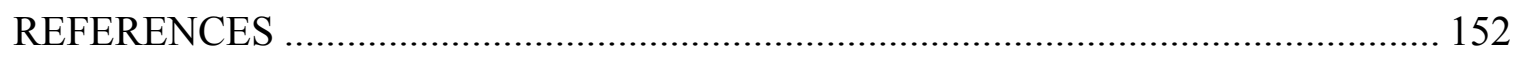

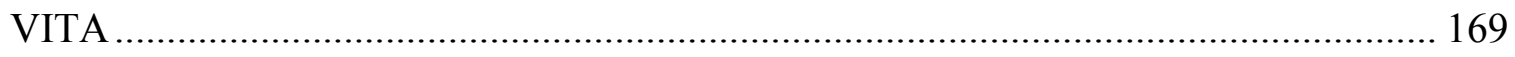




\section{ABBREVIATIONS}

AMF-Asian Monetary Fund

APEC-Asia Pacific Economic Cooperation

APT-ASEAN Plus Three

ARF- ASEAN Regional Forum

ASEAN- Association of Southeast Asian Nations

ASPAC- Asia-Pacific Council

EAEC-East Asian Economic Caucus

EAEG-East Asian Economic Group

EAS- East Asia Summit

EASI- East Asian Strategic Initiative

FDI- Foreign Direct Investment

MITI-Ministry of International Trade and Industry

MOFA-Ministry of Foreign Affairs

PAFTA- Pacific Free Trade Area

PECC-Pacific Economic Cooperation Conference

SDF-Self-Defense Forces

TAC- Treaty of Amity and Cooperation 


\section{CHAPTER I INTRODUCTION}

This dissertation seeks to examine the fundamental structure of and disclose dynamic changes in the relations of the three dominant powers influencing not only the prosperity but also the stability of the Asia-Pacific region: China, the United States, and Japan. This research reassesses the China-U.S.-Japan trilateral relationship using the balance of power conceptual framework, with a focus on their growing cooperation and check-and-balance interactions in regional institutions. All three nations have been actively engaging in AsiaPacific regional institutions, including but not limited to the APEC, the Regional Forum (ARF), Six Party Talks, the Asian Development Bank (ADB), and the Council for Security Cooperation in the Asia-Pacific (CSCAP) according to the Japan Center for International Exchange statistics (1999).

Relations among China, the United States, and Japan constitute some of the most complicated and dynamic in the contemporary era. Each corner of this trilateral relationship is facing domestic and security challenges that could reshape its position in this relationship and its policies toward the others. Since the end of the Cold War, China, the U.S., and Japan have been successful to different levels in developing their trilateral relations, but crucial challenges remain as new tribulations have emerged on all fronts, such as trade and maritime territory disputes in the East China Sea and the South China Sea (Kristofer, 2009).

On the one hand, the trilateral relationship has experienced encouraging and positive readjustments. Despite historical conflicts and differences of interests, the China-U.S.Japan relationship has featured increased and advanced engagement, especially through rounds of high-level military dialogues in reaction to confrontations occurring among them 
and also through the strategic economic dialogue. The growing strength of East Asia has effected a change in attitudes and attention in the United States. In a speech prior to the 1993 Seattle APEC summit meeting, U.S. Secretary of State Warren Christopher said, “As we approach the next century, America must once again look west — west to Asia and west towards a Pacific future." China has sought to improve relations with the United States and Japan to seek a peaceful environment and ensure its further development. Japan, facing a growing Chinese neighbor and U.S. interests in coming back to Asia-Pacific, has tried to balance its relations with the two countries and maximize its benefits from this trilateral relationship. All three nations have acknowledged, on different occasions, that it is in the common interest of China, the United States, and Japan to collaborate in efforts to prevent and resolve regional conflicts, such as conflicts on the Korean Peninsula and the Senkaku Islands (Diaoyu Islands) as well as the cross-strait tension between Beijing and Taipei (Nathan Beauchamp Mustafaga, 2014).

On the other hand, these three countries still have fundamental differences in their interests in and visions for the regional order and the global structure. Each of these three countries desires to take the lead in regional affairs in the Asia Pacific region and each is afraid of letting the other powers seek dominance. China, the United States, and Japan all have different concepts of how security should be organized in the Asia-Pacific region. China holds a strong stance on the security issue and territorial disputes as it perceives them and repetitively addresses that disputes should be resolved among states that are directly involved in the disputes. The U.S. intervention and stand on the South China Sea dispute and the Taiwan issue have aroused discontent in Beijing. 
In 2010, China surpassed Japan in terms of nominal GDP and became the world's second largest economy. However, manifestations of China's rise in the region came even before 2010. China especially started to reassert its influence in Asia-Pacific after the 1997 Asian Financial Crisis. Tensions rose in the trilateral relationship, as China's quest for regional dominance was perceived as having happened at Japan's expense and as a threat to the influence of the United States.

Since the 1980s, Japan, previously the largest economy in East Asia and with military protection by the U.S., had enjoyed prevailing influence in Asia Pacific. However, Japan is now facing China's challenge to its dominance both economically and militarily. In addition, military protection by the U.S. has not been as secure and positive as it appeared to Japan in 1952 when the Treaty of Mutual Cooperation and Security between the U.S. and Japan was signed. Japanese leaders are considering the future role of the Self-Defense Forces and the Japan-U.S. Security Treaty while at the same time tackling domestic economic problems, such as a high debt-to-GDP ratio and a declining and aging population.

The United States, even though it has a strong naval presence in East Asia, has to balance the rise of China with careful calculation, as the U.S. military is already overstretched with commitments on almost all continents (Layne, 2009). Faced with economic stagnation at home and pressure to reform its military strategy in the Middle East, the United States needs to reconsider its strategy to maintain and increase its influence in East Asia and the Pacific.

In 2014, Beijing devoted an enormous amount of attention to preparing for the APEC summit, which it hosted. For China, hosting the summit provided a precious opportunity 
to showcase not only its development and modernization but also its ability to claim leadership in regional affairs. More than 20 world leaders, including Barack Obama and Shinzo Abe of Japan, attended the major international meeting during the summit to discuss regional trade and investment deals. Advancement of cooperation in pushing the agenda of establishing a free trade agreement among the APEC members was one of the key objectives of the summit. As a result, the cooperative side of the picture was highlighted in the media. While regional institutions often convey a process of generating and emphasizing common interests, this research attempts to explore the context of striking diversities of interests and motives that are often buried under the cooperative picture.

\subsection{Research Question}

The research question of this dissertation is why the United States, China, and Japan have increased their cooperative interaction in regional institutions in the Asia-Pacific region, despite having different visions of the future power structure of the region, as all three countries want to contain the influence of the others and maintain or expand their own sway in the region. In recent years, particularly facing China's rapid growth, some U.S. policy makers have advised that the Asia Pacific region is poised to enter a tumultuous era, induced by the revival and intensification of interstate confrontations among the United States, China, and Japan (Betts 1993/1994; Friedberg 1993/2004). However, with the expansion of regional institutions, one could hardly deny that one general trend in the region has been moving in the direction of conflict reduction with the increase of multilateral agreements developed to address common interests. 
In this dissertation, I propose to examine the following fundamental topics so as to clarify the task ahead: 1) How has the China-U.S.-Japan trilateral relationship evolved? 2) What is the role of regional institutions in each state's foreign policy toward the others? 3) What are these three states' policies toward regional institutions? 4) What are the mechanisms that determine these three nations' policies toward regional institutions? 5) How can we redevelop the balance of power conceptualization based on the dynamics of the China-U.S.-Japan relationship?

\subsection{Hypotheses}

Multilateral interaction has grown to be a key feature of dynamic relations among China, the United States, and Japan. The trilateral relationship is now increasingly evolving within a multilateral framework in addition to a classical bilateral one. With the challenges that the multilateral negotiations of the WTO are facing, including difficulty in reaching consensus and an asymmetrical power relationship between the North and the South, regional institutions have been growing as alternative platforms for power balancing among the United States, China, and Japan. Each country's policy toward regional institutions in the Asia-Pacific region is developed in correspondence to the others' policies. The objective of this research is not to downplay the importance of the state or bilateral state interactions but, rather, to stimulate reflections upon interactions in the region by drawing attention to the fact that a growing number of issues are increasingly taking place outside the traditional uni-/bilateral patterns of interaction.

The emergence of multilateralism as a new feature of the trilateral relationship does not yield a picture of the relations among these three powers that is solely positive. With the 
increase of agreements achieved through rounds of negotiation and dialogue, there is a better context for cooperation and a buffer zone against the outbreak of conflicts. However, upon deeper examination of the interactions between China, the United States, and Japan within regional institutions, it can be seen that, while there has been significant advancement of converging differences among the three powers through cooperation, a checking and balancing practice remains. Therefore, the balance of power theory provides an effective explanation, in the multilateral context, when examining the policies of these three powers toward the regional institutions.

However, the emerging role of the regional institution poses a challenge to the balance of power theory because central to that theory is the premise that the stability of the international system can be retained without reliance on political institutions (Singer and Small, 1967). The development and dynamics of the China-U.S.-Japan trilateral relationship can redevelop the balance of power theory with an emphasis on the emerging role of the regional institution as a new unit of analysis when examining power balancing among states.

Another hypothesis is that to explain the China-U.S.-Japan relationship in regional institutions, elements of realist and neoliberal theories need to be integrated with a model of regional institutional balancing that explores the conditions under which this type of balancing occurs and explores the methods often used.

\subsection{Significance of the Research}

There is a gap in the existing literature on the China-U.S.-Japan relationship, as few 
researches have analyzed this trilateral relationship within the regional institutional framework. Extensive literature has already examined the emergence of regionalism; however, the focus of the analyses has been on how regionalism imposes a challenge to multilateralism, not specifically on the nature of a regional institution itself. Few researches have been conducted specifically to examine the role of regional institutions as an emerging platform for check-and-balance behavior by the great powers.

In addition, this research attempts to make a theoretical contribution with the reappraisal of the balance of power theory. There is great diversity and disagreement in defining and modeling the balance of power. As Dina A. Zinnes $(1967,284)$ noted, "the balance of power theory should be subjected to empirical tests, and this should be the redefining stage in an analysis of the meaning and significance of the balance of power". This research reassesses the theory with a dynamic empirical test and attempts to redevelop the theory with the dynamics of the China-U.S.-Japan trilateral relationship. By developing the institutional balancing theoretical framework, this dissertation contributes to providing a different framework to observe countries' strategies and participation in multilateral settings other than traditional institutional discourses. 


\subsection{Structure of the Dissertation}

This dissertation is organized in the following way. Chapter Two critically reviews current literatures on balance of power and institutions. Based on the study of these two schools of thought, an institutional balancing model is developed to provide a theoretical framework to analyze the dynamics among China, the United States, and Japan within regional institutions. Chapter Three discusses the research design of this dissertation, including the research method, rationale, document sources, and selection of a case study. Chapter Four reviews the development of triangular China-U.S.-Japan relations and then respectively examines each country's regional policies - more specifically, policies toward regional institutions. This section notes changes in these three countries' regional policies and their attitudes toward regional multilateralism. Conditions under which regional institutions have emerged as a new platform for balancing between powers are revealed through this section's historical analysis. Chapter Five examines Chinese, U.S., and Japanese interactions within APEC in detail by analyzing institutional documents and governmental archives. Key methods used by China, the United States, and Japan to practice institutional balancing in APEC are discussed and analyzed. Chapter Six discusses the findings, notes the limitations of this dissertation, and proposes a future research plan for this dissertation topic. 


\section{CHAPTER II LITERATURE REVIEW}

The first part of this section examines the literature on one of the oldest theories, balance of power theory, exploring the world system for the purpose of understanding the fundamental structure within which international institutions function. The second part of this section examines two schools of argument, realist and liberalist, about the role of institutions in world politics. Built upon the discussions of the first two parts, the research proceeds to elaborate on the current development of the conceptual framework of institutional balancing.

\subsection{Balance of Power}

Among international relations theories, the balance of power theory is the one with profound significance in framing comprehension of world politics in the World War II period, especially in terms of understanding states' strategic planning and foreign policy. As noted in a few researches (Zinnes, 1967; Niou \& Ordeshook, 1986; Fritz \& Sweeney, 2004), the balance of power theory bears different interpretations and various ways of employing the theory; therefore, revisiting the key hypotheses of balance of power is appropriate and significant. This part of the literature review is designed to make a thorough inquiry into the balance of power theory and its recent reassessment.

Balance of power theory represents a focal principle of the realist approach to understanding the international relations among powers. It premises that states center their foreign policies on pursuing their own national interests that are not mutually beneficial with those of the other states. The balance of power constitutes one of the central concepts 
in Hans J. Morgenthau's Politics Among Nations (1973), where the balance of power is depicted as 'a necessary outgrowth of power politics (p. 167)'. Despite criticism mounted against Morgenthau's comprehensive approach towards the concept, subsequent realists have continued to develop Morgenthau's analysis and insist that the balance of power is an intrinsic feature of international politics and a universal phenomenon that has operated throughout history and affected all regions in the world.

Morgenthau defines power as capability to control the minds and actions of others or ability to influence people to act in a certain way. He observes power in a relational pattern by noting that power is relative as the power of one state can be assessed in terms of its capabilities relative to the capabilities of other states (1973, 32-34). As noted in Richard Little's analysis, embedded in Morgenthau's analysis of the balance of power are two diverse dynamic processes. One process is depicted in mechanistic terms and can be understood as to generate an unstable and dangerous balance of power as an unintentional consequence of great powers' acts in a drive for hegemony. The other process is related to material, ideational, and social factors that advance the effects of the first process and help the great powers in preserving an equilibrium that fosters their common interests and strengthens their collective security $(2007,96)$.

Morgenthau argues that statesmen have always been conscious of their own power base and that of their neighbors. Given that power is a complex term, any attempt by statesmen to evaluate the balance of power involves guesses and the correctness of the assessment can be ascertained only in retrospect. As a consequence, statesmen have no other alternatives but to maximize their power to secure their states' capability of balancing with 
the others, as potential miscalculation cannot be known (p. 204). Morgenthau claims that balance of power is inevitable and all talk of a restraining balance of power is ideological and employed by states with the aim of preserving a power advantage that they possessed at that particular moment. In other words, states acknowledge an interest in maintaining equilibrium so as to hide their real interest in pursuing or preserving hegemony (pp. 21113), which matches with the real case of America's balancing act in Asia.

Even though it is agreed that Morgenthau established the intellectual foundation of the balance of power theory, his comprehensive approach to developing this general theory aroused criticisms of its ambiguity and inconsistency. Latter realists, such as Kenneth N. Walz (1979) and John J. Mearsheimer (2001), have contributed to advancement of the conceptualization of the balance of power theory; however, the inconsistency of the theory has not been significantly improved.

In the book Power and International Relations, Inis Claude lists four different ways of conceptualizing balance of power: as a symbol of international relations; as an indication of the balancing type of policy; as a label describing a specific historical period; and as a denotation of a condition in which the power relationship between states is one of precise or rough equality. Balance of power, when conceptualized in the fourth way, "refers to a situation in which power is literally 'balanced' by equivalent power (Claude 1960, 13)". As Dina A. Zinnes (2014) pointed out in his analysis of the balance of power theory, although this type of conceptualization of the balance of power seems to be descriptive, it can be analyzed as an independent variable in postulations about the relations among nations (p. 270). 
As implied in Inis Claude's analysis, balance of power theory bears variations in meaning as a result of the ambiguity in the concepts of "balance" and "power". Wight (1966) notes nine distinctive modes in which the concept has been used: 1) the principle that power should be evenly distributed, 2) an equal distribution of power, 3) the existing structure of power, 4) an intrinsic tendency of international politics to produce an even distribution of power, 5) a unique role in sustaining the equal distribution of power, 6) a superior advantage in the existing distribution of power, 7) predominance by strong powers, 8) the principle of equal aggrandizement of the great powers at the expense of the weak, and 9) the principle that a state should have a margin of strength in order to prevent the danger of power becoming unevenly distributed (p. 151).

Based on these variations of conceptualization, Richard Little (2007) promotes an alternative way to understand the balance of power as a metaphor and by doing so confers on it the capacity to allow variations. In addition, as argued by Little, understanding the balance of power as a metaphor enables the capacity of transforming the established meaning of the target of the concept (power). The balance of power, according to Little, is in part associated with the concept of anti-hegemonic alliances, which is the postulation that when a great power demonstrates signs of trying to dominate the international system, then other great powers will make alliance so as to preserve their own security by forming an unequivocal counterweight to the ambitious hegemon. Napoleon's and Hitler's attempts to establish a Eurasian hegemony were both counterbalanced and confronted by an antihegemonic coalition of other, relatively weaker, powers. However, the balance of power is not only related to anti-hegemonic alliances. It also represents the idea that states have 
naturally attempted to preserve their security and disseminate their interests by joining forces with other powers to make counter-alliances (Little, 2007, 4-19).

Henry Kissinger noted in the book Diplomacy that there were two balance of power models of the $19^{\text {th }}$ century: one model was the British model and the other model was the Bismarck model. According to Kissinger's interpretation, the British approach suggested that the state engage itself when it fears it has been threatened. However, Bismarck's approach was to prevent challenges from rising powers by instituting close relations with as many parties as possible, by forming overlapping alliances systems, and by using the connected influence to contain the claims of the contestants $(1994,835)$. Bismarck's approach, a strategy of balancing the rising challengers through enhancing interdependence, is akin to liberalism's emphasis on interdependency. This raises a question: Whether the concept of balance of power is or is not a unique realistic concept. This question has also been analyzed in Kristofer Hannesson's paper, "The US-Japan-China Triangle: Shifting Power Balances in East Asia and the World", in which he argues that realism and liberalism can both provide an explanation of the balance of power theory (2009). Deborah Boucoyannis also notes that the basic idea of liberalism is interdependencies between states and an effective international framework which ultimately lead the system to relatively peaceful states of equilibrium where states' self-interests balance each other. The rational, self-interested, preservationist actions of states in an interdependent world lead to a balance of power, even though that balance might not have been their explicit intention (Hannesson, P.10; Boucoyannis, 2007, P.704). 
Booth and Wheeler note that it can be concluded that realists promote the image of the balance of power as an adversarial phenomenon due to their analysis either of human nature or of the anarchical system and liberals advocate the image of the balance of power as a cooperative phenomenon. In the realist analysis, the balance of power is a product of the insecurity experienced by states operating in an anarchic international system (2007). However, the balancing act can be a source for peace and stability too within the realist literature. As Singer and Small (1967) point out, the balance of power serves as a systemic invisible hand to reach stability of the international system. They argue that the defense and justification of the theory clearly rests on the assumption that the stability of the international system can be maintained without reliance on superordinate political institutions. Balance of power as the invisible or unseen hand will function only to the extent that all nations are free to deal with all others as their national interests dictate. Therefore, "it is assumed that every dyadic relationship will be a mixture of the cooperative and the conflictual, with political, economic, ideological, and other issues all producing different interest configurations for each possible pair of nations. The net effect, it is believed, is such a welter of cross-cutting ties and such a shifting of friendships and hostilities that no single set of interests can create a self-aggravating and self-reinforcing division of cleavage among the nations (p. 29)."

Generalized from a few literatures, balance of power can be analyzed at both systemic and regional levels (Morgenthau, 1973; Waltz, 1979; Frankel, 1996; Buzan, 1998; Paul, 2004). Structural realists often view balancing as a law-like phenomenon in world politics, as there is a natural and strong tendency toward balance in the system. As Kenneth Waltz 
puts it, the expectation is not that a balance once achieved will be maintained, but that a balance once disrupted will be restored in one way or another. Balances of power recurrently form $(1979,128)$. The balance of power dynamics also affect regional subsystems, especially when there is a rising power of a regional state or regional coalition. When gaining too much military power within the region, one actor or a coalition of actors may undertake aggressive and predatory behavior in the region. To counteract such insecurity, coalitions of regional states can form balances with or without the association of extra-regional great-power states. For example, after the Cold War, the Association of Southeast Asian Nations (ASEAN) was established as a coalition of small states to balance the great powers, such as India, China, South Korea, and Japan in Asia. The objective of regional balancing is often to generate a stable distribution of power within the aim of preventing war. To achieve balance of power, according to Patrick Morgan, regional states tend to "put great emphasis on autonomy and manipulate their relationships primarily on the basis of relative power capabilities $(1997,33) . "$

While balance of power reflects the outcome of states' behavior, balancing can be regarded as a state strategy or foreign policy behavior for the purpose of preventing a rising power from assuming hegemony, and, if and when that prevention effort succeeds, a balance of power is expected to be present. In other words, in any strategy or practice designed to reduce or match the capabilities of a powerful state or a threatening actor, the various means that states adopt, besides increasing their military strength or forming alliances, should be a part of the balancing analysis. One of the problems of the classical realists' analysis of balance of power is that it limits balancing as a military-security 
concept. However, contemporary world politics attest powerfully to the need for broadening the concept of power balancing. Various manifestations of balancing can be categorized as hard balancing and soft balancing (Paul, 2004, 2005; Pape, 2005).

Hard balancing refers to traditional balancing through military buildups and formal alliance formation to match the capabilities of a state's key opponent. Hard balancing is often conducted under the situation of intensive interstate rivalry and includes strategies such as forming and maintaining open military alliances to balance a strong state (Pape, 2005). Today, hard balancing, albeit in a weakened form, is present in conflict- ridden regions of the world such as the Middle East, where enduring rivalries persist.

Soft balancing occurs when states generally develop ententes or limited security understandings with one another to balance a potentially threatening state or a rising power. The concept refers to a more tactical and indirect balancing behavior for the purpose of delaying, frustrating, and undermining the aggressive power. Soft balancing is often based on a limited arms buildup, ad hoc cooperative exercises, or collaboration in regional or international institutions; these policies may be converted to open, hard-balancing strategies if and when security competition becomes intense and the powerful state becomes threatening (Paul, 2004, p. 3). 
Table 1. Hard vs. Soft Balancing

\begin{tabular}{|l|l|l|}
\hline & Nature of Rivalry & Key Strategies \\
\hline Hard Balancing & $\begin{array}{l}\text { Intense, open, often zero } \\
\text { sum. Relative gains matter } \\
\text { the most. }\end{array}$ & $\begin{array}{l}\text { Open arms buildup, formal } \\
\text { alliances, or both. }\end{array}$ \\
\hline Soft Balancing & $\begin{array}{l}\text { Submerged, non-zero sum. } \\
\text { Relative gains of limited } \\
\text { concern for now. }\end{array}$ & $\begin{array}{l}\text { Limited arms buildup. } \\
\text { Informal, tacit, or ad hoc } \\
\text { security understandings } \\
\text { among affected states, } \\
\text { within or outside of } \\
\text { international institutions. } \\
\text { Preventive strategy. }\end{array}$ \\
\hline
\end{tabular}

(Paul. pp. 10-15)

Key to differentiate soft balancing from hard balancing is that soft balancing involves a tacit non-offensive coalition, instead of a military offensive coalition, built to neutralize a threatening power. For instance, Eastern European states cooperated with NATO to balance the rise of Russia. In the same way, Russia, France, and Germany cooperated in the UN Security Council to prevent the United States from initiating war against Iraq in 2002-2003. China promoted the Shanghai Cooperation Organization to softly balance against the United States (Song, 2013). These instances of cooperation are limited security cooperation understandings short of formal open alliances and are preventive in nature.

The international system is not experiencing the same level of hard balancing as it did during the Cold War period and does exhibit more attempts at soft balancing in varying degrees (Paul, 2004). Three factors have led to this transformation: predominance of U.S. hegemony after the Cold War, growing interdependence as a result of economic globalization, and rise of the common enemies of transnational terrorism and 
environmental degradation. All these three factors have made today's international system very costly for actors to form balancing coalitions by striking military alliances or engaging in an intense arms buildup. The next logical step for actors concerned with their security is to exercise low-cost soft balancing. The first factor seems to be passing away as many scholars now note that the U.S. overextended itself in economic and military terms and is experiencing the end of it role as the world hegemon due to its decline in the global trade regime and problems arising from its imperial overstretch. However, given the status quo of the international system, there is still a power gap between the rising powers, such as the BRICS (Brazil, Russia, India, China, and South Africa), and the U.S. as the superpower. Several studies argue that the U.S. has adopted a soft balancing strategy against rising powers as it can not afford the costs of a traditional hard balancing strategy, given the high level of interdependence between the countries (He and Huiyun, 2008; Song, 2013). Therefore, the dynamics call for a broadened concept of balancing and encourage more analysis of soft balancing.

\subsection{Analysis of Institutions}

Since the turn of the millennium, there has been a key growth of interest in political science and economics in institutional theory and institutional analysis. Institutions, as noted by Beeson Mark (2005), are part of an intricate dialectical process that both shapes and is shaped by contingent human activities. Theoretical discussions varied in their explanations of the question: whether the institution constrains the behavior and interest of states or the states' interests and relationships determine the structure and operation of institutions. Different theoretical perspectives offer different answers. 
Liberalists, especially neoliberalists, often stress the cooperative aspects of international organizations and emphasize the role of international organizations in addressing common interests and diminishing differences among participant members. Robert O. Keohane has played a crucial role in developing "neoliberal institutionalism" (1977, 1987, 1989, 1998) and highlighting the increasingly interconnected and interdependent nature of the international system. Keohane and Joseph S. Nye firstly developed their complex interdependence discussion, which argues that we are in a world in which security and the use of force matter less and countries are connected by multiple social and political relationships, in Power and Interdependence published in 1977. Later, they revisited their original discussion through a number of articles $(1987,1988)$. Keohane and Nye basically argue that the use of force has become increasingly costly for major states as a result of four conditions: risks of nuclear escalation; resistance by people in poor or weak countries; uncertain and possibly negative effects on the achievement of economic goals; and domestic opinion opposed to the human costs of the use of force. Thus, the interaction among states will be displayed in multiple channels, rather than limited to military channel as before. Developed from that premise, Keohane and Nye argue, "In a world of multiple issues concerning national security, the potential role of international institutions in political bargaining is greatly increased. In particular, they help set the international agenda, and act as catalysts for coalition-formation and as arenas for political initiatives and linkage by weak states (1977, P.30)". They also noted that it has become increasingly costly for states to turn away from participating in international institutions as a new pattern of interdependence (1998, P.88). 
Keohane and Nye accept much of the conventional 'realist' view of international relations, which argues that states inherently pursue power, and this is a function of states' material capacities. What makes Keohane and Nye's argument depart from orthodox realism is their belief that, other than competition, states also have a capacity for cooperation for mutual benefit. International institutions, which may be inter-governmental organizations, conventions, or international regimes, play crucial roles in socializing states into such cooperative behavior (Keohane, 1989). In this view, the impact of a fundamentally anarchical inter-state system can be influenced by the establishment of various international institutions, which are constructed to address common concerns or resolve collective action problems. Neoliberal institutionalism believes in the capability of institutions to address and construct common interests among the participant states and to deemphasize military and political rivalry among them by accelerating collective cooperation.

Keohane and Nye's analysis of interdependence is developed based on the concept of asymmetrical interdependence, which notes that asymmetries exist in interdependent relationships and can be a source of power. Distribution of power in international institutions is thus considered in Keohane and Nye's analysis of interdependence. Distribution and relations of power in international institutions have been key questions often addressed by realists.

Realists are often described as skeptical about the importance of international institutions in constraining states' behavior. Realists in all lines characterize international organizations, not in terms of cooperation to promote the general welfare as liberals do, 
but rather as a form of collusion among powerful oligopolistic actors to serve their perceived interests at the expense of the "others". The international institutions not only reflect asymmetrical power distribution but also enable the great powers or international "high society" to generate further advantage through negotiation with weaker states. Therefore, international institutions can be regarded as an order imposed by a few dominant and essentially satisfied actors (Jervis 1983, 1986 and Kissinger, 1994). Edward Mansfield $(1995,600)$, based on the notion of institution as a form of collusion, argues that "states and interest groups have an incentive to capture international institutions because they can generate power for those that control them. Actors that gain power within an institution have the ability to set its agenda and influence the distribution of benefits and costs among members.”

With the realist camp, neorealists argue that emphasis on relative gains in states' relations could fundamentally obstruct international cooperation promoted in international institutions (Waltz 1979, 105; Mearsheimer, 1994; Grieco, 1990, 29). According to neorealist analysis, states are not only concerned about the distribution of gains but also concerned about defection in the anarchic international system. John Mearsheimer (1994), even though acknowledging the existence and development of the international institutions, forcefully staked out an extreme position arguing that international institutions are epiphenomenal. Mearsheimer asserts that institutions "have minimal independent influence on state behavior" and, as a result, "matter only on the margins (p. 42)".

However, Randall L. Schweller and David Priess emphasize that there are differences within the realist camp about international institutions (1997). Traditional realists, unlike 
neorealists, acknowledge the importance of the international institutions in world politics. The two camps, as Schweller and Priess note, vary in their definition of key concepts, such as system. Grounded in the neorealist perspective, Waltz, by using terms such as 'systems theory' and 'systems level', makes the term 'system' effectively a synonym for structure. Waltz also argues that structure should be singled out from the characteristics of units, their behavior, and their interactions as it functions as a separate factor $(1979,79)$. However, for traditional realists, the international system is composed of not only units and structure but also interactions. Barry Buzan and his colleagues observed that "interaction is crucial to the concept of system, for without it, the term system has no meaning (Buzan, Jones, and Little 1993, 29). Snyder also argues that the inclusion of interaction in defining a system is helpful in that it allows the inclusion of process variables, such as institutions, norms, and rules to be considered to have effect on the operation and dynamics of world politics (1996).

Within the realist camp, there is another stripe that contributes to the debate on international institutions. In response to the increased complexity and massive economic and social changes since the end of the Cold War, a new school within the realist camp emerged, which is called "modified structural realism" (Krasner, 1983). Modified structural realists posit that international institutions serve three vital foundations: First, international institutions facilitate the creation of peace and stability by filling the gap between rising political participation and weak governing institutions and consequently prevent the spread of praetorian regimes (Snyder, 1991). Second, inclusion of new members can be offered by existing members as carrot in exchange for a strong effort on 
the part of the target to dampen conflicts that it previously had with the existing members (Hopf, 1992). Third, membership in international institutions gives weaker states more opportunities to voice their needs and concerns to influence the policies of stronger neighbors (Grieco, 1993). In addition, modified structural realists accept the neoliberal view that a demand exists for international institutions, even in the realm of international security. As Snyder depicted in his analysis of the problem of security in the changing European order, the solution to solve such problem in the region is to adopt "a middle point between the Hobbesian instinct for insulation and the neoliberal instinct for institutionalized activism" $(1991,139)$.

Therefore, even though for realists international institutions reflect the interests of the dominant, established powers and the distribution of capabilities that existed at the time of their creation, it does not mean that realists do not contribute to the discussion on international organizations. Rather, within the realist camp, there are literatures that value the impact of international institutions on reprocessing and rebalancing the status quo through interactions over the course of the development of international institutions. Realists' analysis of international institutions complements the neoliberal analysis of international institutions because neoliberal discussion has often neglected the close association of international institutions and regulations with policies of the status quo. 


\subsection{Institutional Balancing Model}

This research contends that the two schools of arguments discussed above both partially explain the role of multilateral institutions in structuring international relations. To offset the shortcomings of these general theoretical schools, I explore further the concept of an institutional balancing model at the interface between neorealism and neoliberalism to explain states' behavior.

The academic discussion of institutional balancing started from Joseph Grieco's examination on the regional monetary integration of the European Union in the 1990s. The 'voice opportunity' hypothesis, developed by Grieco in accordance with the core assumptions of neorealism, argues that states consider collective arrangements in institutions in terms of both the practical benefits those arrangements provide, and also the opportunities for effective voices. Effective voice opportunities was elaborated by Grieco as:

Institutional characteristics whereby the views of partners (including relatively weaker partners) are not just expressed but reliably have a material impact on the operations of the collaborative arrangement... states (and particularly weaker states) may view effective voice as a 'good' that they enjoy as part of being in a collaborative arrangement, and enjoyment of a satisfactory level of this 'good' may itself be a basis for assessment by states of their satisfaction or dissatisfaction with the arrangement $(1996,280)$.

Due to these effective voice opportunities, Grieco claims that all states, especially weaker states, are guaranteed that they will have a voice in the discussion of the agreement and the implementation of the agreement. One could easily notice that Grieco mainly emphasizes effective voice opportunities of the weak states and applies his hypothesis to argue that weak but influential states, such as France and Italy, use institutions as a means 
to constrain strong states, such as Germany, and to increase their weight in regional decision-making (1995).

Kai He developed Joseph Grieco's 'voice opportunity' hypothesis, but with the focus on institutions as a platform for these kind of effective voice opportunities for all participant states. He established the institutional balancing model. He defines institutional balancing as "to counter pressures or threats through initiating, utilizing, and dominating multilateral institutions, as an overlooked realist strategy for states to pursue security under anarchy $(2008,492) "$.

Within this model there are two independent variables. The first variable is the degree of economic interdependence, which, according to He, serves as the main aspect that makes states choose a new realist balancing strategy rather than military alliances to cope with threats or pressures from the system. The second variable is the distribution of capabilities in the international system. The dependent variable in this model is state balancing strategies in the international system, which is determined by the interplay between the two independent variables $(2008,492)$. The model is well set as it pinpoints key factors that influence states' balancing behavior. However, upon further review, only factors at a systemic level have been taken into consideration in this model. Domestic factors and institutional factors have been neglected in He's model.

According to He, balancing behavior can take form in two types: inclusive balancing and exclusive balancing. Inclusive balancing means states practice norm/rule-biding to constrain other state's behavior or control and manipulate agendas to address issues related to their interests in multilateral institutions, which echoes Grieco's analysis of "voice 
opportunities". He adds another form of institutional balancing, which is exclusive balancing. Exclusive balancing refers to states consolidating their political and economic unity to resist pressures from outsiders. The interaction between the two independent variables and state's choices of these two methods of balancing can be summarized as the following table indicates:

Table 2. Independent Variables and State's Choices of Methods of Balancing

\begin{tabular}{|c|c|c|c|}
\hline \multirow[b]{2}{*}{$\overline{0}$} & \multirow[b]{2}{*}{ Unipolar } & $\begin{array}{l}\text { Economic Interdependence } \\
\text { Weak }\end{array}$ & Strong \\
\hline & & $\begin{array}{l}\text { Power balancing (hegemonic } \\
\text { and colonial wars are possible) }\end{array}$ & $\begin{array}{l}\text { Institutional Balancing: } \\
\text { Exclusively (Hegemon vs. Others) }\end{array}$ \\
\hline. & Bipolar & $\begin{array}{ll}\text { Power balancing between } \\
\text { blocs; (superpower wars } \\
\text { relatively unlikely) }\end{array}$ & $\begin{array}{l}\text { Institutional Balancing: } \\
\text { Exclusively between the two blocs; } \\
\text { inclusively within the blocs. (Led } \\
\text { by the two superpowers). }\end{array}$ \\
\hline 高 & Multipolar & $\begin{array}{l}\text { Power balancing (high } \\
\text { possibility of war among great } \\
\text { powers) }\end{array}$ & $\begin{array}{l}\text { Institutional Balancing: Inclusively } \\
\text { (binding target states into } \\
\text { institutions) }\end{array}$ \\
\hline
\end{tabular}

(He, 2008, 494-497)

While He further developed the institutional balancing conceptual framework by adding independent variables and specifies balancing types, his analysis has one problem that also affects Grieco's work. Both analyses, when examining states' interaction in institutions, focus on how small states use institutions to balance the threat from great powers but do not include discussion of great power interaction within institutions.

The model of institutional balancing can be envisaged in two various ways: the legal and the political. Envisaged from a legal point of view, institutional balancing is a manifestation that the institution and the states must act within the boundaries of their competence. From a legal perspective, institutional balancing is a constitutional principle, 
which the member states and the institutions must respect, and any form of disrespect can be sanctioned by a court of law. From a political perspective, it can be viewed as a means of depicting the manner in which the relationship between the institutions is built (Goh, 2004). The institutional balancing model does not contend that the creators of the treaties create a balance of sharing of powers, such that the weight of every institution is equal to the other, rather it implies that the institutional structure is grounded in the sharing of powers among the institutions formed by the treaties.

According to Goh (2004), there are certain smaller powers which are more effective than the rest, for instance, Australia is a smaller power in its region but it is more effective because of the closer tie that it enjoys with the United States, hence it plays a major role in the balance of power in the Asia- Pacific. Significantly, perhaps Japan and India may appear to be effective powers in their region but they do not have enough power to exert independent influence as opposed to the United States and China. In this context, however, institutional balancing has increased the power of India in its region, although it is not as effective as US and China. US- China relations are the pivot of the treaties with the smaller powers in the Asia- Pacific region. For example, US-Japan treaties, as a result of the Nye initiative of 1995, provoked Chinese distrust about the agreement over the Taiwan issue. Smaller powers have been trying to employ the use of policies similar to those used by the major powers to join the institution and add stability in the region. Moreover, smaller powers try to lure major powers through institutions so as to promote their benefit on the ground of non-interference. Basically, smaller powers economically depend on the super powers, a factor that gives the bigger powers greater political status in the region. Therefore, 
institutions are like mechanisms that the Asian- Pacific states use to win associative balance of influence.

The era of globalization is ever increasing, whereby there are benefits from maintaining interstate interactions. Institutional balancing has gained prominence in several regions and indeed in the entire world. There are institutions such as ASEAN or APEC which have continued to give a template for further development of institutions. ASEAN for instance has multiplied its diplomatic bid and capabilities in the region of its influence and has also managed to form a far-reaching relation with the super powers (Aris, 2009). Furthermore, ASEAN has played a key role in enhancing security collaboration among its member states. While doing this, it has welcomed major powers to several forums, which has helped them in controlling those powers in institutions and gaining experience in defense and security matters. ASEAN Regional Forum (ARAF) has been in the forefront since 1994 in addressing a number of security matters in a multilateral setting among the member states such as the United States of America, China and Japan (Funabashi 1995). In the same light, ASEAN has also enhanced security coordination among its members. All these efforts have been in a bid to control major powers and to effect a balance of power in the region. Moreover, ASEAN and APEC have ensured that their former enemies are brought together. The institutions have also become a platform through which China, Japan and US can come together to settle problems. In a sense, institutions have become a functional problem-solving mechanism that consolidates leaders and the member states across the region to find solutions to emerging problems. 
The ever increasing interest in building intergovernmental institutions and organizations indicates that there is a growing need for the consolidation of the institutions at the political level, probably because of the economic interdependence that has been increasing in most parts of the Asia- Pacific region. It is now apparent that the Asia-Pacific region is building institutional balancing and interactions that could be having effect on behavior and policy calculations (Aris, 2009). Because the smaller powers have now focused on both soft institutionalism and political affairs, non-U.S. forums like ASEAN have turned out to be so significant for them. These institutional forums have become new opportunities for institutional balancing power while reducing the significance of the conventional balance of power.

Institutional balancing is significant for both the smaller states and the big powers. Big power states, like the United States of America, China and Japan gain from the global institutions in that they give their share to the establishment of the coalitions (Deng 1997). Furthermore, they can ease the exercise of power because the structures of the institutions reflect some of the things which are valued by the stronger states. Meanwhile, the smaller powers benefit from the global institutions, if they can convince the stronger states to become members of the newly formed institutions and thereby constrain their powers (Friedman \& Selden, 1971). Additionally, smaller states can also use the international institutions to delay the plans and the operations of the stronger states, giving the weaker side a longer time to prepare.

The above-mentioned institutional balancing strategies have enabled the regional powers to bring changes to their policies. Over the course of the time, the leadership of the 
Chinese has begun to show positive attitudes towards the institutional balancing of power, which has further strengthened the relationship of the three states (Donald 2002). The positive relations of Japan, the United States of America, and China and their skillful diplomacy in the constructive issues in organizations like ASEAN Regional Forum have helped them in the rapprochement with other hostile states. The three states have increasingly become comfortable and adept while handling their issues in these institutions.

This research seeks to expand the current discussion on institutional balancing through detailed observation of China-U.S.-Japan interaction within regional institutions to examine systematically the interaction between great powers and between great powers and small powers within institutions. This research will also analyze institutional balancing within the larger theoretical framework of soft balancing to generalize conditions under which it is exercised and how it is exercised by states. 


\section{CHAPTER III RESEARCH METHODOLOGY}

This research uses qualitative research methods consisting of archival research and a case study. One of the objectives of this research is to explore historically the policies and practices of the U.S's., Japan's and China's relations and their policies on and interactions in regional institutions in the Asia Pacific. Therefore, archival research is one of the key methods in this research project. This study explores documents released by these three countries that record their policies towards each other and regional institutions. Archival research is conducted to explore four questions: 1) What are these countries policies towards the Asia Pacific; 2) what are these countries policies towards the regional institutions; 3) how have their policies changed or have they remained constant; 4) what are the reasons behind changes or consistency?

To assess China's policies, China's yearly-published white papers, and Chinese CCP leaders' public speeches are examined along with China APEC Development Council's documentation on China's policy and involvement in the APEC. Regarding American documents, congressional hearings on America's foreign policy towards Asia and regional institutions will be the focus of examination. On Japan's side, documents published by the Japanese Ministry of Foreign Affairs will be the target for evaluation. Mutual evaluations and documentations are included in this research project to minimize inaccuracy of the data.

Besides archival research examining U.S.-Japan-China relations and their foreign policy towards regional institutions in Asia, this project includes a case study exploring in detail America's, Japan's, and China's policy and practice towards the APEC. The case study is designed to observe these three countries' involvement and interaction in the 
APEC through three sub-questions: 1) what are the general foreign policies that the U.S., China and Japan have taken towards APEC; 2) have these policies exhibited continuity or, if they have changed, what were changes in policies and the contexts and factors that caused the changes; 3) how have China, the U.S., and Japan interacted with each other and addressed the others' interests during and after APEC's meeting?

APEC is selected as the targeted regional institution for the following reasons: First, as the first institutional expression of Asia Pacific regionalism APEC has a long history that enables extensive historical analysis. Established in 1989, APEC was a significant departure in regionalism in the Asia Pacific region(Heseltine, 2003). Even though there were several attempts to forms regional institutions similar to the scale of APEC before, most of them failed. Second, even though APEC has the longest history, APEC is not the most well established one in terms of institutional development. While APEC's flexible institutional mechanism brought the institution lots of criticism from institution analysts, it allows more room for negotiation and interaction between different powers without institutional constraints. In addition, the leader's summit of APEC ensures that interaction between participant countries is at the leaders' level, instead of only at the related governmental department level. Third, China, the U.S., and Japan all have been actively involved in APEC and have interacted with each other within this multilateral framework since the 1990s, which provides an ideal institutional setting to examine their policies towards and interaction with each other.

Documents that have been released and published by APEC are studied. In addition, U.S. congressional hearings about America's policy towards APEC, China's publications 
from the China APEC Study Center at Nan Kai University and the Chinese Taipei APEC Study Center at Taiwan Institute of Economic Research, and Japan's scholarly research on Japan's role in APEC are examined to evaluate each country's policy and calculation before they sit down together at the negotiation table. 


\section{CHAPTER IV ANALYSIS}

\subsection{China-U.S.-Japan Triangle Relations}

Extensive research has been done analyzing the China-U.S.-Japan trilateral relationship from various aspects such as history, security and economy. A large number of the researches have been conducted from a historical perspective that documented the interactions among the three powers (Funebashi, 1995; Vogel, et al 2002; Ming, 1999). To varying degrees, China, the U.S., and Japan, are all being forced to address a new agenda based on the emerging priorities of the post-cold war era. In principle, it is in the interest of all three states to cooperate in efforts to resolve and prevent regional conflicts, such as on the Korean peninsula and in South Asia, as well as to ensure that cross-strait differences between Beijing and Taipei do not escalate tensions that might draw in external actors, namely the United States, to keep the peace. However, uncertainties about the future and other interests may limit practical cooperation measures in areas where long-term national interests may conflict. This section examines literatures with direct relevance to the subject of this dissertation.

Betts (1993) and Friedberg (1993) argue that in the wake of China's rapid economic growth and political pursuit of becoming a regional power, Asia is poised to enter a more tumultuous era, to be occasioned by a revival and intensification of interstate rivalries, such as enduring rivalries between China-Japan and China-America. Historical context has to be examined to understand why China-Japan and China-America have been analyzed as enduring rivalries in several literatures. 
While Japan was a tributary of Imperial China until the end of the Tang dynasty, Japan emerged to become a key rival of Imperial China after the Meiji Restoration. Accompanying the rise of Japan was the worsening of the Sino-Japan relationship, which reached its nadir from the outbreak of the Second Sino-Japanese War until the end of the World War II. Even though the China-Japan relation has been gradually improving especially after Shinzo Abe became the Prime Minister of Japan, conflicts remain on various grounds. Japan's refusal to admit and document the Nanjing Massacre in its history textbooks has always been at the center of controversy. In the summer of 2012, there was renewed tension between China and Japan over their competing sovereignty claims in the South and East China Seas, respectively.

In the case of relations between China and the U.S., Beijing and Washington were outright hostile toward each other in the 1950s and 1960s. Their armed forces fought in Korea and Vietnam and engaged in repeated confrontations across the Taiwan Strait. In 1969, USSR planned a nuclear attack on China, which was prevented by President Nixon's intervention. There was a period from 1972, when Richard Nixon visited Beijing, to 1989, when the Tiananmen Square crackdown occurred, during which the two countries cooperated strategically to balance the power of the USSR. However, the cooperation was not strong enough to be qualified as a formal alliance and this informal alliance did not last very long. With the rapid growth of China's economic and military power, China's threat to the current balance of power, especially to the hegemonic position of the United States, has since the early 21 st century become a concern for the U.S. "China threat" has become a heated and much discussed term in academic researches especially after the appearance 
of Bill Gertz's book The China Threat: How the People's Republic Targets America (2002). Especially on the U.S. side, academic discussion along with discussion in the media advanced the image of the U.S. and China as rivals. Along with the trend, Bush called for a containment policy towards China in order to prevent China from becoming a hegemonic power in Asia.

While some researchers highlight the conflicts among these three powers, some researchers, for instance Steve Chan (2013), argue that the general trend among these three powers has been moving in the direction of rivalry abatement. Diehl and Goertz note that the evolution of rivalries reflects these three states' changing domestic conditions and leadership thinking. Chan expands this argument and notes: "the move of governing elites to economic development as the overriding policy priority; a concern that in turn requires stable external relations, promotes economic interdependence, and keeps the dynamics of rivalry in check and sometimes even puts them in reverse. These elites' internationalist economic orientation ... also encourages multilateral ties or what has been described sometimes as 'omnidirectional diplomacy' $(2013,2$.)”. Steve Chan's analysis is not limited to examining the China-U.S.-Japan trilateral relationship, but extends to the broader context of the Asia-Pacific region.

Besides Steve Chan's analysis, there is other research examining the interaction among U.S.-Japan- China within the regional context in the Asia-Pacific region (Dosch \& Mols, 2000). A common criterion of international regionalism is shared interests or common concerns. Therefore, most existing researches about the regional institutions in the Asia Pacific region concentrate on singling out common interests. However, upon deeper 
examination, the region is constructed through differentiated interests among great powers with each taking a position in regional affairs to ensure its interests. The regional institutions are not products of or based on naturally occurring common interests, but reflections of power balancing in the region. Hence comes the social construction process of the term "Asia Pacific".

Arthur Power Dudden (1992), Mark Borthwick (1992) and Manfred Mols (2003) have asserted that if we look at the origin of the term of "Asia Pacific", it is indeed a creation of North America. They claimed that it was American endeavors to reach Asia, particularly China, and the corresponding penetration of the Pacific Ocean that raised a Pacific consciousness among those actors that are now actively involved, including traders, missionaries, members of various administrations, geographers, and strategic thinkers. The process started in the United States then as a reaction to Commodore Perry's opening of Japanese ports in East Asia, and finally as part of an increasingly complex historical process that reached its conclusion at the New Hampshire conference, which sealed an internationally recognized claim about the Asia Pacific as a geostrategic entity. Following the logic of this statement, it will not be hard to make an argument that the construction of the Asia Pacific as a separate regional identity, other than Asia, reflects America's strategic interest in Asia. America attempted to secure its influence to balance out the regional power through making itself a member of the Asia Pacific region.

Barry Buzan $(1998,2003)$ examines this phenomenon in a more detailed way. Buzan notes that the "Asia-Pacific" is a constructed entity that cannot be as easily identified as East Asia, South America, the Middle East, or Europe can. The "Asia- Pacific" is in one 
way to a far larger extent than for other "recognized" regions, which are composed of units of geographical closeness or cultural similarity, a common denominator of social consensus, or more precisely, a consensus about the constitutive quality of institutions and organizations, of defining powers including the United States, Japan, Australia, and China

as a late comer. In a more general picture, Buzan argues that regions should be objects of analysis in themselves, particular locations where one can find outcomes and sources of explanation. He attempts to address why does region as a type of territorial subsystem come into being and sustain itself as a feature of the wider international system? This research reflects on Buzan's analysis of region and tries to extend the discussion to see how "region" has become an emerging platform of check-balance interaction between China, U.S., and Japan.

\subsection{China's Policy Analysis}

This part of the research uses a historical perspective to explore China's regional policy and its policy specifically towards regional institutions. Sorting through the historical moment, this section notes the changing pattern of China's regional policy development and notes the types of institutional balancing that China has developed through years of engagement in regional institutions in the Asia Pacific.

\subsubsection{The origin and development of China's regional policy}

China's relation with its neighboring countries is one of the most dynamic relations interwoven by historical and multifaceted interaction at political, economic, military, and cultural levels. China is a country with the most neighboring countries, bounded by 
fourteen countries on land and six countries by sea, a few of which still have border disputes with China. Since 1949, China's communist party leaders have attempted to develop a comprehensive approach aiming at pursuing better relations with these neighboring countries. By historically analyzing the development of China's regional foreign policies this research divides China's relations with its neighboring countries into three phrases: i) 1949 - 1978; ii) 1978 - 1996; iii) 1996 -Now.

\section{PHASE I: INITIAL FORMATION (1949-1978)}

In 1949, when the People's Republic of China was established, the primary strategic objective for its communist party leaders was maintaining and strengthening China's sovereignty. The geopolitical relations that China was facing in the neighborhood were complicated. Some of its neighboring countries in Southeast Asia and South Asia still waited to be liberated. In addition, the Cold War between the United States and the Soviet Union divided China's neighboring countries into two independent groups: one group inclined to follow the western countries led by the United States and a group inclined to follow the Soviet Union. In order to insure the safety of China's Chinese northern boundary and provide China a generally secure environment, China adopted a foreign policy of "leaning to one side", which is to the side of the USSR under the socialist camp. About three months prior to the founding of the PRC, Mao Zedong announced that New China would support the Soviet Union in international affairs. On February 14, 1950, China and the USSR signed the Sino-Soviet Treaty of Friendship, Alliance, and Mutual Assistance. The alliance was mainly a military agreement, which committed the two sides to come to each other's aid if either were attacked by Japan or the United States (Xia, 2008). 
Two other principal factors also led to the adoption of this "leaning to one side" policy: the CCP's communist ideological inclinations and America's support for the Nationalist regime of Chiang Kai-shek during the civil war. In addition to ideological confrontation, the Chinese Communist Party regarded the U.S. as a serious threat to the PRC, because the United States had been supporting the Chinese Nationalists during the Chinese civil war and Washington refused to cut off relations with the Nationalist government in Taiwan. The relation between the PRC and the USA worsened with the outbreak of the Korean War in June 1950, which disrupted possible stabilization of Sino-American relations. The PRC and the United States locked into a three-year war in the Korean peninsula from June 1950 to July 1953. After China entered the Korean War in October 1950, the U.S. perceived the PRC as a major threat to its key interests in Asia, and to the security of Japan.

Another important step that China took during this period was introducing and promoting the "Five Principles of Peaceful Coexistence" as a framework under which its foreign policy would be conducted. In 1954, the "Five Principles of Peaceful Coexistence" were proposed and written into the joint communiqués concluding the visits by India's Prime Minister Jawaharlal Nehru and Burma's Prime Minister U Nu to China. In 1955, at the Afro-Asian Solidarity Conference at Bandung, Indonesia, Premier Zhou Enlai defined the "Five Principles of Peaceful Coexistence" as: 1) respect for sovereignty and territorial integrity, 2) mutual non-interference in domestic governance, 3) mutual non-aggression, 4) equal benefits, and 5) peaceful co-existence. All these principles appealed to the developing world which, like China, had experienced the brunt of colonialism. This doctrine was proposed to establish a norm for interactions between the New China and 
these countries. A number of scholars believe that this doctrine symbolizes the initial formation of China's diplomatic strategy towards its neighboring countries in Asia (Zhang, 2010; Chung, 2010; Xia, 2008).

Under the guideline of the "Five Principles of Peaceful Coexistence", China developed diplomatic relations with its neighboring countries and coped with border disputes with its neighbors. In Asia, the first country with which China established diplomatic relations was India, which was the first non-socialist country that recognized the PRC. After India, China successively established diplomatic relations with Indonesia, Myanmar, Pakistan, Afghanistan, Nepal, Cambodia and other neighboring countries. At the initial stage of communication, Zhou Enlai brought out the strategy of influencing Southeast Asian countries through trade. Taking China and Indonesia for example, on July 1953, China and Indonesia signed a trade agreement to exchange rice and rubber. Indonesia no longer abided by the United Nations' embargo on China and sold rubber to China. China in return sold essential food supplies, such as rice, to Indonesia. Afterwards, personal exchanges increased significantly. In June 1954, a Chinese economic delegation visited Indonesia, which was followed by the Indonesian Prime Minister's visit to China. After that, China's relations with Indonesia, according to a few scholars, entered into a honeymoon period (Zhang, 2010; Peter, 1998). Zhou Enlai believed that trading was beneficial for establishing relations with China's neighboring countries and important for breaking the blockade imposed by the West (Communist Party Literature Research Center, 1997). By the mid1960s, China solved a significant number of major border disputes with countries like Nepal, Pakistan, Afghanistan, and Mongolia in the region through bilateral negotiations. 
With the collapse of Sino-Soviet friendship by the early 1960s, Mao stated in 1964 that Asia, Europe, and Africa, together with oppressed nationalities that were waiting to be liberated, constituted a "Middle belt" (zhong jian di dai) between the socialist and capitalist blocs. The rise of nationalism as a result of Communist infiltration in the Third World had posed an increasing threat to the existing power system. It was within this area that China attempted to stand out as the world's leading revolutionary state, threatening not only Western democracy, but also Moscow's claim to the leadership role within the Socialist bloc. In geopolitical as well as ideological competition with the USSR for leadership of international communist community, China provided substantial amounts of material aid to violent insurrection in Asia. During the 1960s, China began to support revolutionary communist movements within many of these countries. In the process, China also sought to distract the Soviet Union's energy and attention away from their common border (Mitchell, 2009). However, with the death of Mao and the end of the "Cultural Revolution" in late 1976, the Chinese authorities soon ceased providing training, moral support, and material assistance to communist revolutionary movements in Asia (Chung, 2010).

PHASE II: ECONOMIC DIPLOMACY (1978-1989)

The second phase started after the 1978 revolutionary reform and lasted until the fourth Community Party Conference held in 1992. This phase featured the redefined strategy of peaceful diplomacy with neighboring countries in Asia. China's domestic political, economic and social structure had changed dramatically, which also caused the reconstruction of China's external strategy in Asia. In December 1978, the Third Plenary Session of the Eleventh Central Committee was successfully held. At this conference, the 
Chinese government announced that China should from now on focus on economic development. Thereupon, the government under the leadership of Deng Xiao Ping, launched economic reforms and opened up foreign policy. Afterwards, the primary objective of China's external strategy was redefined as "stabilizing the surroundings, anchoring the Asia-Pacific, and approaching the world." Pursuing stable relationships with China's surrounding neighbors in Asia became a necessary strategy for China's economic development, to attract foreign trade and investment. This has been all the more so in the last 20 years with the rapid erosion of any form of ideological moorings for the Chinese party-state, such that economic growth to increase the material welfare of the people has become the main legitimating basis for the maintenance and popular acceptance of CCP one party rule.

Compared to the previous period, China's regional strategy during this phase further developed with an increased emphasis on the economic aspect. The guiding principle changed from the dominance of the development of peaceful coexistence to a more comprehensive package including the promotion of "Collective Economic Prosperity". (Zhang, 2014).

PHASE III: Multipolar Foreign Policy (1990-1997)

During the late 1980s and early 1990s, China's domestic politics and its international situation were both complicated. With the end of the Cold War in the early 1990s, it was clear that the USA, the Western European countries, and Japan wanted to construct a "New World Order." Proclaimed by George H.W. Bush in September 1991, the "New World Order" was constructed on Western democratic and capitalist values to be spread to the rest 
of the world (2009). China, in the aftermath of the 1989 Tiananmen incident, was suffering economic embargo and diplomatic isolation by major Western countries and Japan. Aside from having to deal with the adverse consequences of the Tiananmen incident, a major consideration of China's early post-Cold War foreign policy was to counter the "China Threat Theory" spread in the Western countries and the perception of being too aggressive towards the South China Sea dispute by its Southeast Asian neighbors. Philippines, Vietnam, Brunei and Malaysia compete for the ownership of these islands in part or in whole with one another and with Taiwan and China. Another concern for China was what the authoritarian leadership by the $\mathrm{CCP}$ observed by other Asian countries as the dominant and threatening power (Chung, 2010).

In response, Deng laid down two main post-Cold War foreign policy paths for China: pursuing anti-hegemonism and establishing a new multipolar international order of politics and economics (Pan \& Wang, 2001). These two policy prescriptions were encapsulated in one principle: "Tao Guang Yang Hui, You Suo Zuo Wei," meaning that China should "keep a low profile and bide its time, while getting something accomplished." (Glaser, 2008). "Tao Guang Yang Hui” can be comprehended as China should first and foremost mind its own business and be neither a leader nor a challenger, but rather a participant or co-builder of a new international order (Pan \& Wang, 2001).

Multipolarity is one of the key elements of the New International Order. China's multipolar worldview can be tracked in its officials' public discourses. In 1990, the secondgeneration leader, Deng Xiaoping explicitly elaborated the multipolar worldview by stating: "The situation in which the United States and the Soviet Union dominated all international 
affairs is changing. Nevertheless, in the future when the world becomes three-polar, fourpolar or five-polar, the Soviet Union, no matter how weakened it may be and even if some of its republics withdraw from it, will still be one pole. In the so-called multipolar world, China too will be a pole, we should not belittle our own importance: one way or another, China will be counted as a pole". The third-generation leadership basically inherited this worldview from Deng's administration (He, 2006). In 1992, the third generation Chinese communistic party leader Jiang Zemin also stated "the current world is undergoing dramatic historical changes. The bipolar structure has ended, different forces have started to re-divide and re-merge, and the world has been moving toward a multi-polar direction" (1996). As enunciated by Jiang, the rudimentary tenets of the new international order are: “i) respect for state sovereignty and different political, economic, and cultural orientation of nations, meaning non-interference in the domestic politics of states, ii) shelving differences and finding common grounds for cooperation, iii) resolution of disagreements through peaceful means, and iv) promoting multi-polarity in the international system (1996).”

By further advocating multi-polarity as the future structure of the world politics, China projected to bond with major actors in thwarting what it perceived as U.S. attempts to constrain China strategically and diplomatically in the global affairs and to contain China's influence in the Asia Pacific, with support from Japan. As a first step to having good relations with other countries in the Asia-Pacific region, China re-established diplomatic relations with Indonesia and Vietnam successively in 1990 and 1991 and established official relations with South Korea, Singapore, and Brunei. In 1993, Chinese Premier Li 
Peng noted in his government's annual work report that "active development of beneficial and friendly relations with neighboring states, in striving for a peaceful and tranquil surrounding environment, is an important aspect of our country's foreign affairs work." (Xiong, 2004). However, in the aftermath of an confront in 1995 between Chinese and Filipino warships off the Mischief Reef, in 1996, the Southeast Asian states in an ARF meeting in Brunei collectively condemned China's aggressive action. Singapore's senior statesman, Lee Kuan Yew, although was against the "China Threat Theory" and an ethnic Chinese himself, warned "we should expect that once a country becomes wealthy, it would want to have everything." (Zhang, 1999).

PHASE IV: “Good Neighbor Policy” (1997-Now)

During this stage, there has been a re-orientation of Chinese diplomacy from bilateral relations with great powers as a foreign policy priority, particularly toward the USA, to attaching similar importance to neighboring states. This change was caused by a series of events, rather than just one. The turning phase lasted from the onset of the 1997 Asian Financial Crisis through the US bombing of the Chinese Embassy in Belgrade in 1999 to the creation of the Shanghai Cooperation Organization in 2001. The 1997 Asian Financial Crisis created an opportunity for the PRC to use its economic strength to create an image of a responsible regional player. During the Asian financial crisis, China gained a number of "friends", such as Thailand, by providing economic support. China made a symbolic move by publicly rejecting to devalue its currency, when the U.S. failed to promptly respond to the Asian financial crisis with necessary assistance. While this movement was not appraised highly in the West, the majority of Asian countries found this move 
contributed significantly to financial stability in Asia (Ministry of Foreign Affairs of the People's Republic of China, 2000).

The next turning point was the embassy-bombing incident. He Kai argues that the 1999 Kosovo War surprised the Chinese leaders and changed Chinese leaders' perception of the regional distribution of power. The Kosovo War and the embassy-bombing incident replaced China's multipolar illusion with a unipolar reality. China was surprised at the power of the U.S. and its ability to successfully bypass the authorization of the United Nations to bomb a sovereign state in the name of "humanitarian intervention" unopposed worldwide (Xiong, 2004). Russia's weak reaction and China's concern as expressed explicitly by the Chinese government could not impose any restriction on U.S.-led NATO' military action while most states in the world either supported or kept silent about the bombing of Serbia by the U.S. and NATO.

In addition, the bombing of the Chinese embassy forced the Chinese leaders to reassess their optimistic multipolar worldview of the early 1990s and to rethink their power status and China's foreign policy towards the U.S. Soon after the embassy bombing, Jiang rephrased his vision of the world system and stated that "after the Cold War, the world moves to a multipolar direction, but the formulation of multi-polarity needs a considerably long period of time (2004)". In 2000, the Chinese White Paper on National Defense clearly noted that Chinese military strategists officially recognized that the U.S.-led unipolar world remained instead of declining and stated that there was a gap of military strength between U.S. and other powers in the world. The frequency of using the term 'multi-polarization' in the People's Daily declined dramatically after the 1999 Kosovo War and embassy 
bombing (2006). Since 2000, instead of referring to the world system as "Duo Ji Hua" (multipolarity) or "Yi Chao Duo Qiang “(One super power and many great powers), China's People's Daily generally has used "Mei Guo Ba Quan" (U.S. hegemony) to describe the world system that China is a part of.

With this change of worldview, China started to reemphasize its agenda at the regional level. China's increasing efforts in expanding its sway in the Asia Pacific region coincided with its core foreign policy objectives: 1) peaceful environment, 2) securing and maintaining reliable access to the raw materials and markets necessary to support China's continued economic expansion, 3) the creation of a more evenly balanced and decentralized international system (Porter, 2010). With the changing view of America's power status as previously elaborated and the concern of threats from the U.S., China rather than merely focusing on competing with the U.S. at the global level chose to concentrate on working on its own neighborhood. As Terence Wesley-Smith argues, nowadays the primary external interest of China is in its neighborhood (2010).

By the late 1990s, the Chinese CCP leaders recognized that the interweaving of financial flows and international trade had made the world one of complicated interdependence. Ensuring stability of financial and investment environment, regional and international trade, and security of global energy supplies have thus meant that China's interests and its sway must expand beyond bilateralism. While China has participated in regional institutions such as APEC, SCO was the first one that China initiated and has a full institutional body comprising a secretariat, charter, Council of National Coordinators, annual meetings of councils of Heads of States, Heads of Government, and full ministers, 
anti-terrorism structure, as well as distinctive committees to coordinate cooperation at the senior official level.

To reduce regional threat perceptions of China, increase common interests, and raise mutual trust, Beijing began publicly promoting a policy of "neighborliness, trustworthiness and partnership" with neighboring countries in Asia Pacific in the report of the Sixteenth CCP Congress in 2002.

\subsubsection{China's foreign policy towards regional institutions in Asia Pacific}

Compared with other regions in the world, such as Western Europe, multilateralism is under-developed in the Asia-Pacific. The Cold War polarization between communist and anticommunist countries; political, economic, and cultural diversity and heterogeneity in the region; and the strong commitment to preserving sovereignty and political independence in the region, which initially resulted from a history of colonial rule, all these factors contributed to the lack of a multilateral tradition. America attempted to establish the Southeast Asian Treaty Organization (SEATO), which was organized to be a NATOtype multilateral security regime. In September of 1954, SEATO was officially formed in Manila, but it never got very far. By the early 1970s, members started to withdraw from the organization. Even though the organization was named as a Southeast Asian regional institution, it only had two members from the Southeast Asian region: the Philippines and Thailand. Most of the SEATO member states were countries located elsewhere but with an interest in the region or the organization. ${ }^{1}$

\footnotetext{
${ }^{1}$ https://history.state.gov/milestones/1953-1960/seato
} 
The Soviet Union also tried to establish an "Asian collective security system", but most countries in the region rejected this maneuver outright. On June 8, 1969, Leonid Brezhnev noted at the World Conference of Communist Parties "we believe the course of events $^{2}$ is also placing on the agenda the task of creating a system of collective security in Asia." (Horelick, p. 269), which triggered the Soviet's efforts to promote an "Asian collective security system" to attract potential partners.

During the early phase of establishing multilateralism in the region, the only successful attempt was the formation of the Association of Southeast Asian Nations (ASEAN) in 1967. ASEAN was an attempt not by major powers but by Southeast Asian countries to survive the struggle of major powers in the region and to maintain a nonaligned identity outside of any major-power security system. In the post-cold war period, functional economic interdependence in terms of trade, investment, and human resources has increased significantly, leading to a common desire for greater standardization and coordination of economic activities. In the security sphere, the strong desire of the Asia-Pacific countries to maintain regional stability and prosperity in the post-cold war period compelled many of them to take collective measures to deal with potential dangerous spots such as Cambodia, the Korean peninsula, and the South China Sea. The successive rise of Japan and China as major regional powers, and the relative decline of influence of the Soviet Union and to a lesser extent the United States, also facilitated a multilateral approach to minimize the disruptive effects of the power transition in the region (Wang, 1998).

\footnotetext{
2 "The course of events" refers to the Soviet-Unions' long-standing proposal for the convening of a conference on European security.
} 
Even though a new multilateral political, economic, and military structure was forming in the region, to what extent China should adopt a multilateral approach in addressing issues directly involving its interests, as well as other regional issues, was still in question in the Chinese foreign-policy establishment. Strategically, how China should perceive the importance of multilateralism in the Asia Pacific was an unclear question when regional institutions began to form. Not until the 1980s did China's perception of multilateralism in the Asia Pacific region begin to develop and then slowly. Even though Chinese elites and scholars started to pick up on the concept of multilateralism, the triangular structure between regional major powers and sub-regionalization dominated China's decision making in regional affairs during the 1980s.

At the beginning of the 1980s, China responded slowly to American and Japanese grand strategies for the Asia-Pacific. During this period, China was learning incrementally how to 'fit' into the region. Prior to 1984, China had openly opposed multilateral regimes as arenas for American hegemonic domination that would infringe on its sovereignty. Beijing's position on regional regimes started to change in 1984 and China gained observer status in PECC (Pacific Economic Cooperation Council). Since then, "Asia-Pacific fever" (ya tai re) reached epidemic proportions in Beijing. Gaye Christoffersen recalls in his work that Chinese scholars were exceedingly enthusiastic about the notion of China participating in and influencing the formation of regional regimes (1996, pp. 1070-1071). However, the initial euphoria was tempered by the realization that China's regional status was that of a developing country. Ambivalence toward participation in the Asia-Pacific multilateral regimes continued as Chinese elites and scholars were pondering the question of how 
should China be placed in these regimes. China's capabilities were insufficient to justify the regional leadership position, held by Japan, but unwillingness to accept a subordinate position led to China's ambivalence and its search for an alternative arrangement.

Ma Chaoxu and Duan Jianfan published the first Chinese book discussing China in the context of the Asia-Pacific region and asserted that China was an Asia-Pacific country. This book placed China at the bottom of the pattern in trade competition with ASEAN countries (1988). In the 1980s, even though China had launched the economic reform and successfully transformed from a self-reliance economic development model to an exportled one, China's role as raw materials supplier put it closer to the bottom of the industrial product cycle. However, China's aspirations placed China in a joint hegemony with Japan. Through a number of deliberate political economic choices in the 1970s, Japan became a dominant economic power in the 1980s. In the 1980s, there was a massive shift in relative power between the United States and Japan, exemplified by the surge in both Japanese economic and techno-military capabilities. And in Asia there were signs of a growing regional orientation fueled by greater economic interdependence and a relative decline in the U.S. economic position versus the Japanese and the newly industrializing countries (NICs). Japan surpassed the United States as the country with the greatest amount of total foreign direct investment (FDI) in the Asia Pacific.

Sino-Soviet rapprochement during the 1980s thus coincided with China's need to confront the gap between status and capability in the Asia-Pacific. Concern with Japanese dominance in the region drove China to incorporate the Soviet Union in 1985 in proposals for trilateral cooperation with japan. The series of initiatives for Sino-Soviet-Japanese 
economic cooperation discussed in the Chinese press in 1985-1986 were instrumental in provoking a Soviet response, Gorbachev's 1986 Vladivostok and 1988 Krasnoyarsk speeches. China viewed the Soviet as a potential collaborator rather than a competitor. The Soviet would join China, and NICs, and ASEAN countries in resisting "U.S.-Japan dominance and exploitation" [meiri kongzhi he liyong] (Bei, 1989). Soviet participation was needed in a Northeast Asian sub-regional regime and it was needed in the triangular strategies China would formulate to counter American and Japanese grand strategies.

In the late 1980s, China's triangular logic transferred from the Sino-Soviet-Japan strategic triangle to the U.S.-Japan-China triangle. One of the factors that drove the transition was the growth of China's economic and military power during the 1980s. Another factor was the growing trade friction between the U.S. and Japan, which led Beijing to believe that China would hold a pivotal position due to U.S.-Japan friction (Xia, 1990). Another reason for this transition was that Russia had not improved its regional status and had not been able to assume a more active role in regional affairs. Internationally, neither the U.S. nor Japan wanted increased Russian participation in the Asia-Pacific. Domestically, Russian's domestic instability prevented the formulation of a clear strategy towards the Asia Pacific.

Besides triangular structure, sub-regional structure also dominated Chinese discourses. Chinese continued to argue that the dominant trend was toward sub-regionalization in Asia rather than toward a multilateral regional regime with many different cultural traditions and values. The sub-regional economic circles, that is, the Sea of Japan economic zone, the 
Northeast Asian economic zone, and ASEAN were viewed as more viable regimes because each sub-region brought together culturally homogenous areas.

Gaye Christoffersen also argues that Chinese conceptions of sub-regional regimes and triangular structures, rather than multilateral regimes, provided a theoretical framework for explaining China's Asia-Pacific participation in the 1980s (1996). American and Japanese conceptions of regional formations shaped China's views of the Asia-Pacific to a greater degree than did its domestic determinants. However, neither American nor Japanese grand strategies provided an arena for China to learn the norms of multilateral regimes in the region in this period of time. From the U.S. China learned the advantages of triangular logic. From Japan, China learned to accept a hierarchically ordered East Asia, in which China has sought joint hegemony with Japan.

As discussed in the previous chapter, the end of the Cold War brought dramatic change in the region. China was well aware of the transformation of the Asia Pacific power structure. It realized that the importance of the triangular relation between China-U.S.Japan was gradually being supplemented by the political and economic clout of the then six ASEAN states. Altogether, a new multilateral political, economic, and military structure was forming in the region (1991). After the Cold War, multilateral institutions flourished in the Asia Pacific region. The region was characterized by the proliferation and dynamics of multilateral institutions, such as the enlargement of the APEC and ASEAN, the inception of the ASEAN Regional Forum (ARF), and the institutionalization of ASEAN Plus Three-China, Japan, and the Republic of Korea (APT). Multilateral institutions became an alternative for states to seek for economic cooperation and security 
under conditions of anarchy and are new arenas of strategic interactions between China and other Asian-Pacific countries after the Cold War.

In the 1990s, there was also a growing discussion about the multilateral logic of developing China's regional policy in the Asia Pacific. Some Chinese argued China should seek a pivotal position by exploiting U.S.-Japan bilateral tensions. Other Chinese argued that a deterioration in U.S.-China or U.S.-Japan relations would hamper Sino-Japanese relations, and thus the three sets of bilateral relations within the triangle must improve jointly. The latter group thought China should promote multilateral cooperative behavior rather than exploit bilateral tensions (Gong, 1995). There were a few institutions that advocated multilateralism as an alternative to triangular logic and sub-regional regimes: China Institute of Contemporary International Relations and China's APEC headquarters at Nan Kai University. Both institutions devoted efforts to discussion of how China should fit into the larger spheres of regional multilateral regimes. These organizations though had little influence on China's foreign policy during the early period of time but contributed to the growing discussion of regional multilateral regimes in the epistemic field.

Since China's economic growth largely relied on its opening-up policy, it was not difficult for it to embrace the idea of multilateral economic arrangements in the early 1990s. For China, economic development is the highest priority in its national strategy, and it will do anything possible to promote economic growth, including participating in multilateral economic arrangements. Deng's famous "Cat Theory" also applies to China's motivation to engage in regional economic institutions. Multilateral economic cooperation with capitalist countries seems to be an alien idea in the Marxist Doctrine. However, if this 
"black cat" could help China catch mice (promote economic development), it was seen as a good cat. In addition, growing economic status and military power made Beijing assured of its pivotal position in regional institutions. Beijing no longer struggled with the position as a developing country, but strategically accepted the status and positioned itself as a developing country in regional institutions to make allies with other Asian Pacific developing nations.

APEC was the first multilateral institution established in the Asia Pacific aiming at promoting regional economic cooperation. Japan and Australia actively pushed for the establishment of APEC in 1989. The U.S. did not take the initiative in this matter and, in fact, the U.S. almost missed the APEC train partly due to U.S. ignorance of regional economic cooperation in Asia and partly due to the fact that Australia's original APEC was "Asia plus Australia" without the U.S. The U.S. case will be elaborated in detail in the next section. ASEAN and China did not initiate APEC because they did not have enough economic power to take the lead despite their stunning economic growth in the 1980s. China joined APEC in 1991. Deng Xiaoping's market-oriented economic reform placed trade and investment as the highest priorities of China's economic development. Beijing believed that economic reform and openness were the only way for China to be strong in order to seek for great power status. Therefore, the idea of APEC was inherently compatible with China's pattern of economic growth.

For China, joining APEC not only served its economic interests, but also meant a breakout from the Western isolation after the Tiananmen Incident. Eighty percent of China's foreign trade and ninety percent of its Foreign Direct Investment (FDI) came from 
the Asia Pacific region as of 1991, but China did not take part in any official sub-regional economic cooperation arrangement (Sheldon, 1996). Some scholars argue that, at the beginning, the Chinese approach to this forum had different goals than promoting multilateralism: Beijing used multilateral regimes as a means to assert China's regional power claims while simultaneously using them to reduce bilateral tension with the U.S. and Japan. What was embedded in Chinese's initial participation in APEC was still the triangular and sub-regional logic (Gong, 1995; Chen, 1992; Du, 1992). However, different from PECC, APEC offered Beijing a forum in which China could learn multilateralism.

Despite being more open to economic multilateralism, China was more reserved about multilateralism in the security domain. China had a more complex view of security multilateralism in the 1990s. On the one hand, according to Beijing's analysis, in the postcold war period, while Europe and other parts of the world had been plunged into protracted turbulence, the Asian-Pacific region had remained relatively peaceful and stable. Since the 1990s, no new interstate military conflict had broken out in the region, while tense issues of the past such as Cambodia and North Korea's nuclear capability had eased considerably. China itself for the first time since 1949 faced no direct military threat (Yan, 1994; Guo, 1996). Therefore, China was in no rush to establish a multilateral security regime in Asia Pacific. As Yan Xuetong remarked, in the period of economic growth, security interests had gradually given way to economic interests in China's national agenda (1994).

On the other hand, China did not see its security environment as all peaceful and without challenges. The security threat to China came from two directions: national separatism and territorial disputes. National separatism pointed to separatist movements in 
Taiwan, Tibet, and Xinjiang. Territorial disputes pointed to the numerous territorial disputes China had with its neighbors. However, China did not see multilateralism as the most effective approach to addressing these security concerns. In China's view, the AsiaPacific region was characterized by diversity rather than uniformity. Countries in the region were still divided over what kind of regional security framework should be established, thus competition of leadership was inevitable in multilateral settings. Still considering itself relatively weak in political aspects among the major powers in the region, China did not want to be involved in such a struggle too early as it could be in an unfavorable position. Another important consideration was that a formal multilateral security mechanism required a high degree of military transparency, for which China was not yet ready (Evans, 1996).

Nonetheless, China understood that under the post-cold war circumstances, multilateral security was a trend reflecting the legitimate concerns of small and mediumsize countries seeking a stable and predictable regional security order. China definitely did not want to be left out of this trend. Therefore, joining and participating in the ARF was like "crossing rivers by touching stones" to China. In comparison with APEC, ARF, a multilateral security institution in the Asia Pacific, was more controversial and challenging for Chinese decision makers. In 1994, China joined ARF and Qian Qichen suggested in his ARF speech,

Consultations on an equal footing and peaceful settlement should serve as norms in handling disputes between countries in the Asia Pacific...bilateral and multilateral 
security dialogues and consultations in various forms should be promoted in order to enhance understanding and confidence. (Xinhua News Agency, 1994)

In China's pre-1995 ARF discourses, building trust and confidence between China and ASEAN states was a primary reason for China to join ARF. On the one hand, it was rational because of distrust developed from historical conflicts between China and ASEAN. On the other hand, it reflected China's passive and skeptical attitude towards ARF at the start of its participation. Subsequently, in 1994 and 1995, what China did at the first two ARF meetings was to slow down the development pace of ARF and barricade substantial security cooperation among ARF members. At the beginning, China took tough stances on the South China Sea dispute and the Taiwan issue and insisted that these two were internal affairs of China therefore should not be noted in the Chairman's Statement of ARF. In 1995, China began to adjust its policy on the South China Sea dispute with ASEAN countries. In February 1995, China occupied the Mischief Reef near the Philippines and afterward encountered unprecedented diplomatic pressures from ASEAN countries. Qian Qichen, instead of refusing to discuss the onging South China Sea dispute, was among the first to propose the South China Sea disputes for discussion at multilateral setting. Qian openly agreed that contesting claims should be resoluted on the base of the U.N. Convention on the Law of the Sea, and he assures that there would always be freedom of navigation in the area (Bandar, 1995). As Rosemary Foot points out, since the 1995 ARF meeting, China started to distinguish the Taiwan issue from the South China Sea disputes. The former issue was still seen as a diplomatic taboo for China, but the latter gradually approved to be debated in multilateral settings (1998). 
In addition to moderating its policy on the South China Sea dispute, China's attitude towards ARF experienced a noticeable transformation. Since 1996, China has become more positive towards ARF. For example, at the 1996 ARF meeting, China proposed a dialogue on defense conversion and comprehensive security cooperation, although the proposals made were in the safe areas of military law and medicine. There were three main aspects of this dramatic improvement in China's ARF policy in the mid-1990: engaging the ASEAN, supporting the ARF, and enhancing ASEAN's role in the regional power configuration. All these three aspects served China's preference for multilateralism in the post-Cold War era as discussed in the previous section.

ASEAN Plus Three

Since the late 1990s, China has strategically stimulated the development of the ASEAN Plus Three (APT) summit meetings to limit U.S. influence in the region by collaborating with other members to exclude the U.S. from the arrangement. APT cooperation started in 1997, including all ASEAN members and three East Asian countries: China, Japan and South Korea. Some argue that APT is an incidental cooperation of the 1997 financial crisis (Damiri, 2011). However, even though the 1997 financial crisis was a catalyst, the idea of APT had its origin in the proposal for a East Asian Economic Group (EAEG).

The EAEG proposal, featuring exclusivity and racially defined regionalism, was important as an early signal of East Asian regionalism but has not received adequate attention in academic analysis of APT. In 1990, Malaysian Prime Minister Mahathir bin Mohamad proposed to establish EAEG as a regional bloc of East Asian and Southeast 
Asian countries. The proposed group would include the 10 Southeast Asian states, Japan, China, and Korea but would notably exclude both the United States and Australia, representing an idea of an exclusivist East Asian regionalism. EAEG, upon establishment, would perform as a counterweight to emerging regional blocs in North America and Europe. The creation of the EU under the 1992 Maastricht Treaty and the signing of the 1992 NAFTA were important factors in Mahathir's argument that East Asia needed to develop its own regional bloc (Cheng, 2001).

At the initial stage, China indicated its support for Malaysia's proposal but did not push the agenda because China perceived the EAEG would be dominated by Japan. The EAEG ultimately failed as it faced strong opposition from the U.S. and Australia. Under President George H.W. Bush, the U.S. successfully pressured its main Asian allies, especially South Korea and Japan, not to support the EAEG. Japan, which was assumed to take the leading role, adopted a moderate attitude due to the United States opposition. Besides Japan, fear of U.S. backlash was enough to persuade the majority of East Asian states, whose political and economic survival depended heavily on access to the U.S. market in the early 1990s, to reserve their support for the EAEG.

East Asian states then rejected the EAEG proposal in favor of an East Asian Economic Caucus (EAEC) within APEC forum. Under President Bill Clinton's administration, the U.S. continued to counter the EAEG but did so mainly by promoting APEC. Therefore, EAEG and APEC are often observed as competing institutions at that time. U.S. support for APEC is commonly perceived as a successful proactive move against EAEG and other similar exclusive East Asia-type arrangements. 
The 1997 Asian financial crisis was a turning point that renovated Mahathir's exclusive East Asia ideas. Regional resentment toward IMF and U.S. response to the crisis strengthened interest among ASEAN countries in exclusive East Asian regional institution, which then took the form of APT framework. Therefore, at the beginning, APT was constructed to enhance monetary and economic cooperation between Southeast Asia and Northeast Asia and lessen the economic dependence of Asia on the United States and international financial institutions like IMF. From then on, the APT has been an essential element for advancing East Asian regionalism. Albeit it was originally a informal gathering, since 1997, APT became a regularized and formally institutionalized institution. In November 1999, the APT leaders at the Manila summit agreed on comprehensive economic cooperation and resolved to tighten economic connections among East Asian countries in order to integrate ASEAN with China, Japan, and South Korea. The early focus on monetary and economic integration has been broadened to include cooperation in politics, security and culture exchange. However, some scholars claim that APT cooperation rarely go beyond declarations of intention in non-economic issues (Astarita, 2008).

Several researchers claim that the U.S.'s indifferent and arrogant policy during the 1997 economic crisis was the key factor that facilitated the establishment of APT (Cheng, 2001; Suetsugu and Oyama, 2005) and directly caused the exclusion of itself in this growing association. In contrast to the U.S., although China was not directly affected by the crisis because of its inconvertible currency, China did share ASEAN'Ss concerns about 
the necessity of regional economic and monetary cooperation and contributed to stop the spreading and worsening of the crisis.

The 1997 economic crisis not only gave China a opportunity to offer help to Southeast Asian countries and represent itself as a responsible regional power as discussed before, but also taught China an invaluable lesson about the negative effects of economic interdependence and globalization. Regional economic and financial cooperation thus became imperative for China's economic growth, an imperative shared by the ASEAN countries that were drastically impacted by the globalization of the financial capital market. Therefore, China adopted a more active and effective policy towards the APT than it had adopted towards the EAEG. Following Deng's guideline of "taoguangyanghui, yousuozuowei" (concealing capabilities and making accomplishment), China's APT policy aimed at restructuring the regional balance of power, both economically and strategically.

China had two strategic purposes behind its economic diplomacy in APT: to deepen its economic engagement and to enhance its political influence. In terms of economic goals, China intended to strengthen its economic connections with the ASEAN countries through the FTA program and advance its economic growth. In 2001, after China joined the WTO, China progressively lost its bargaining power in international trade as it was constrained by its commitment of tariff reduction to the WTO. Instead of letting the ASEAN countries attain the tariff benefits and market access from the WTO, at the 2000 APT summit, China took the initiative to negotiate an FTA with ASEAN countries. At the 2001 APT meeting, ASEAN leaders accepted China's initiative and the two sides reached an agreement to establish the FTA in ten years' time. With this FTA established, there was great potential 
in bilateral trade between China and ASEAN. According to the estimation by the ASEANChina Economic Export Group, the free trade area program would increase China's exports to ASEAN by $55 \%$ and ASEAN exports to China by $28 \%$ (Astarita, 2008). China hoped that the free trade agreement would show its good intention to its Southeast Asian neighbors and gradually expands economic cooperation to the security and political arenas.

Strategically, China has tried to use APT as a platform to establish regional influence and leadership for Beijing in the region. China has used APT as a mechanism to balance the influence of U.S. and Japan in the region in two different ways. Back in 2003, America took in more than three times the share of ASEAN's exports absorbed by China. Since 2003, China's share of all Southeast Asian trade burgeoned at an astonishing average annual pace of 26 percent. However, Southeast Asian countries by no means gave up on the U.S. and in fact some countries still maintain robust bilateral trade relations with the U.S. and try to seek for security cooperation with the U.S. to counterbalance the threat of China in the disputed security areas. APT provides China an opportunity to exercise an exclusive institutional balancing method to use its advantage as an inside member and exclude the U.S. from regional agreements that stimulate regional interdependency.

Within APT, the choice of China, Japan, and South Korea for APT was not only meant to develop cooperation with the strongest East Asian economies, but also represented ASEAN's attempt to prevent any of them from gaining hegemonic status in the region. Balancing and counterbalancing practices within the institutions could be foreseen from the outset. China and Japan are two of the most important actors and competitors for leadership within the APT. While Japan was widely recognized as a potential regional 
leader, it was originally very reluctant to join the ASEAN +3 process for fear of antagonizing the U.S. China seized the opportunity and tried to use an inclusive institutional balancing method by initiating and promoting more agreements that were beneficial to itself and other ASEAN member states, to compete with Japan within in this regional cooperation framework. As Damiri also notes, China's effort to promote comprehensive economic cooperation agreement, which included the free trade agreement that was signed in 2002, overshadowed Japan's importance in the region (2011). However, it is noteworthy that although China had achieved its goal of closer economic ties with the ASEAN countries, how much political influence China could increase in the region by stimulating economic cooperation agreements within the APT remains as a question that needs further observation.

Shanghai Cooperation Organization (SCO)

Besides APT, the SCO is another pillar of China's exclusive institutional balancing practice against the U.S. Distinctive from APT focusing on economic issues, the SCO originally developed to focus on security problems. In comparison with China's role in APT, China is playing a more decisive role in SCO's formation and development. SCO was initially a military confidence-building mechanism through which China and its Central Asian neighbors cut troops in their border regions. Subsequently, SCO advanced to emerge as a comprehensive multilateral institution with a broadened agenda including military and counterterrorism cooperation, intelligence sharing and economic initiatives. In 2001, as a replacement of the original 'Shanghai Five'3 that launched in 1996, China,

\footnotetext{
${ }^{3}$ The 'Shanghai Five' consists of China, Kazakhstan, Kyrgyzstan, Russia and Tajikistan.
} 
Russia, Kazakhstan, Kyrgyzstan, Tajikistan and Uzbekistan officially founded the SCO in Shanghai. Upon its establishment, SCO was declared to operate as a regional security regime, attempting to counter the cross-border, non-traditional security threats known as the 'three evils' ${ }^{4}$. The SCO founding members were alert to point out that the association was not a military alliance, and was not aimed at any third parties (Gill, 2001).

However, since its establishment, SCO has been subject to different interpretations. Some analysts agree with the official statement by SCO members that it is a non-traditional security regime focusing on terrorism and borderland stability and will not become a military alliance (Aris, 2009; Lanteigne, 2006-2007). However, some analysts regard SCO as an anti-western bloc of authoritarian states threatening Western influence in Asia, particularly that from the U.S. (Ambrosio, 2008). Some argue that China's main purpose with $\mathrm{SCO}$ is to control energy supplies in the region, not just to fight against radical Islamic and separatist groups (Marketos, 2009). It is also suggested by others that SCO may be used by Central Asian states for multi-vector diplomacy in global affairs (Blank, 2008). Despite diverse perceptions of SCO, there is a shared perception that the organization was mainly a Chinese initiative. Since 1996, the first group meeting of 'Shanghai Five', China has played a primary role in founding and developing SCO.

China has several motivations in promoting SCO. First, China wants to defend is territorial integrity, given the problem of the Xinjiang Autonomous Region, and ensure the stability of its northwestern frontier. Second, China has strategic interests in Central Asia,

\footnotetext{
${ }^{4}$ The 'three evils' refer to international terrorism, ethnic separatism and religious extremism.
} 
such as its trade and economic opportunities, and more importantly its energy resources. Third, Central Asia is an important link within China's "One Belt, One Road" initiative. Fourth, there was less room for China to play a leading role in founding a multilateral institution in other parts of the world, either because of the presence of long-established multilateral systems (such as ASEAN in Southeast Asia) or because of deep-seated suspicions or long lasting conflict with certain countries in the region (such as in Northeast Asia). The Central Asian states were not strong enough to take the lead in establishing regional cooperation. After the collapse of the Soviet Union, in the 1990s, Russia was not interested in regaining leadership in Central Asia. In the 1990s, the U.S. paid little attention to this part of the world. Instantly after the collapse of the Soviet Union, the U.S. regarded Central Asia as subordinate to its grand strategy towards post-Soviet Russia. U.S. key concerns regarding Central Asia included the denuclearization of, in particular, Kazakhstan and the stability of the newly independent states. Before the $9 / 11$ attacks, US foreign assistance to the Central Asia accounted for only 12 per cent of the amount that given to all the Eurasian states of the former Soviet Union, which reflect the low priority the U.S. gave to this region (Congressional Research Service, 2010). These circumstances gave China an exceptional opportunity to initiate a regional organization in the region, to make use of this organization to promote its power and security in this region, and to use this organization as a mechanism to balance against other challenging superpowers such as the U.S. (Song, 2013).

With the continuing U.S. military presence in the Central Asia after the 2001 Afghan war, China perceived potential threats to its interests and agenda in the region. If the threats 
to China were not instantaneous, most Chinese scholars believed that they were detrimental in the long term, not only in Central Asia but also in its overall neighborhood. (Zheng, 2007, pp. 35-38). The legitimacy of the U.S. military presence in Central Asia derives from its official assertion that U.S. military bases in the region are important to support its operations in Afghanistan. Its military presence in the region is the central part of the global war on terror and ultimately helps reach regional security in Central Asia. Chinese policymakers are skeptical of U.S. intentions and concerned that the U.S. will use the war on terror as a pretext to keep a permanent military presence in its backyard (Zheng, 2007, P. 383).

China has tried to contest U.S. sway in the region through SCO, but was not very successful at the beginning. SCO's reaction to the 9/11 attacks was disappointing. The newly formed organization could not do anything else but a mere nominal declaration, offering moral support for US-led anti-terrorist war and condemning the terrorist attack. It was hard to reach consensus among the SCO partners on whether the U.S. military presence in the region posed a threat. At first, most Central Asian states in fact welcomed U.S. entry into this long-neglected region. Leaders of these countries thought that U.S. participation in regional affairs could be beneficial in a number of ways. Russia was then reluctant to launch and further strengthen SCO cooperation. It was suspicious of China's intention to increase its presence in Russia's traditional sphere of influence. In fact, shortly after the creation of SCO, Russia took the lead in creating the Collective Security Treaty Organization (CSTO), mostly with Central Asian SCO members. Some Chinese analysts regard CSTO as a Russian attempt to countervail the rising Chinese influence in Central 
Asia (Liu, 2007; Zhao, 2010). Thus, China's pursuit of collective action against the United States through SCO tends to be very difficult.

However, things have gradually developed in China's favor as its SCO partners began to share similar views with China on the US role in the region (particularly after the 'Color Revolutions'5 in a number of former Soviet Republics in the early 2000s (Song, 2013). Other SCO partners were more inclined to accept China's proposal to practice military exercises. In 2001, China participated in a Chinese-Kyrgyz joint anti-terrorism mission, which was in fact the first joint exercise of the People's Liberation Army with a foreign military. China further pursued joint military exercises through the SCO framework. On 6 August 2003, at the initiative of China, SCO launched its first multinational military exercise, named 'Lianhe [cooperation] 2003'. All SCO members except Uzbekistan participated in the mission. In August 2005, the first Sino-Russian 'Peace Mission 2005' joint military exercise was held, with only SCO members allowed to observe the event. It was followed by the 'Cooperation 2006' Sino-Tajikistan anti-terrorist military exercises, and the Sino- Kazakh 'Tianshan No. 1' anti-terrorist military exercise (Song, 2013). The 'Peace Mission 2007' joint military exercise was commenced and financially sponsored by Russia, and participated in by all the SCO members. It demonstrated the solidarity of the organization while also trying to mitigate international concern by opening itself to states outside SCO. The 'Peace Mission 2009' Sino-Russian military exercise was held in July

\footnotetext{
${ }^{5}$ Color revolution refers to various movements that developed in several societies in the former Soviet Union and the Balkans during the early 2000s featured with civil resilience and non-governmental actors involvement.
} 
2009 within the SCO framework. In 2014, China hosted SCO’s largest military drills (Song, 2013).

The joint military exercises in the SCO framework are mostly an open expression by SCO states of the organization's legitimacy, solidarity, and strength. China has promoted the joint SCO military exercise as a demonstration to the world, and particularly to the U.S., that states in the region have the determination and capability to fight regional terrorism on their own and to achieve regional security (Song, 2013). In other words, China has tried to build SCO as a substitute to the U.S. military presence, in the name of regional security and stability. Blank (2005, pp. 5-7) clearly points out that the military exercises in the SCO framework have a political dimension. They are largely a Sino-Russian attempt to balance against the United States and its policy in Central Asia.

The case of SCO indicates that China's strategy of initiating and sustaining collective action, including joint military exercises and actions aimed at ousting U.S. military bases from the region. This method of promoting collective action taken by members of the regional institution to combat the influence of non-member states can be regarded as an method of exclusive institutional balancing. However, as we could see from China's experience with SCO, exercising exclusive institutional balancing through collective action could be the most difficult method as it is extremely difficult to reach agreement among the institutional members on collective action aimed at the hegemon.

\subsection{U.S. Policy Analysis}

The U.S. approach to regionalism in Asia Pacific has to be examined in the larger 
context of the U.S. perception of the region and the historical debates about the extent of its legitimate interests in the region. Therefore, this section firstly explores the changing dynamics of the general U.S. strategy towards the region and then examines U.S. policy specifically towards regional institutions and agreements: such as APEC, ARF, APT, EAS, and TPP.

\subsubsection{U.S. policy towards the Asia Pacific}

This section examines U.S. regional policy from three intertwined dimensions: U.S. perception of the region and itself in relation to the region, evolution of its regional strategies, and its attitude towards bilateral and multilateral approach to achieve its objectives and protect its interests in the region. This research notes that the U.S. regional policy evolved through three historical stages with distinctive features: during the pre-1945 period, the U.S. largely perceived itself as an offshore presence; after 1945, the U.S. started to emerge as "security guard" for its bilateral allies and had a predominant power in the region; in the post-Cold War era, the U.S. moved from containment to the quest for a new regional order in which it positioned itself as a regional balancer.

\section{Pre-1945: U.S. as an offshore presence}

The plain fact is that any Western joint action in Asia must carry with it the clear implication that we do not take the Asians very seriously and in fact regard them as inferiors. We should not be able to avoid this implication because that is indeed our attitude. (State Department Memorandum, 1944, P. 260). 
The idea that America's role in the region should be limited to an offshore presence in the pre-1945 era had evolved over two centuries of activity in the Pacific and was bound up in contested notions about 'manifest destiny', 'expansionism' and a 'large' foreign policy. The 'large' policy, as Pratt depicted, represented the spirit promoted by U.S. administrators such as Theodore Roosevelt and Henry C. Lodge, aiming at no less than making the U.S. the indisputably dominant power in the western hemisphere (Pratt, 1932). In spite of the tendency to push westward, military interventions on the Asian mainland were consistently ruled out by successive administrations. For example, the U.S. refused to get involved when Japanese forces invaded Manchuria in 1932, despite enormous pro-Chinese public sentiment. (Issacs, 1958; Treadgold, 1980; Wheeler, 1957). As Akira Iriye has noted, for the U.S. to act in Asia would have required a complete reorientation of American priorities during that period of time (1968).

Involvement elsewhere in Asia, besides Guam, Hawaii and the Philippines, was not considered important prior to the outbreak of WWII. During the war, Europe was quickly designated as America's priority, while the Pacific was of secondary concern (Harrington, 1986). When America did turn its attention to the Pacific, the U.S. military allowed Mountbatten's British Southeast Asia Command (SEAC) to control Southeast Asian operations, focusing its own energies on island-hopping actions against Japan. At this time the State Department also paid little attention to continental Southeast Asia, where it was by and large happy to defer to the British. As noted by Hemmer and Katzenstein, it had no equivalent to a Division of Southeast Asian Affair and generally U.S. relations with the 
region were seen as "extensions of relations with the colonial powers" and were dealt with by the Department's European division (2000).

This perception of being an offshore presence was considered as a natural role for the U.S. during this period of time and continued to influence U.S. decision-making towards the Asia Pacific region in the early post-WWII period. This perception of the region led to the low ranking of the Asia Pacific in American priorities. The U.S. also had not figured out its interests and priorities in the region yet and thus had not devoted itself to developing a grand strategy towards this area of the world.

\section{Post 1945: U.S. emerged as a hegemon}

When American officials came together to debate a postwar regional security arrangement in the Pacific, a consistent theme of their exchanges was the absence of a common idea of how to define the region. Discussions in the State Department repeatedly came back to the question of who should be included in any regional scheme. Where should the U.S. "draw the line" in Asia and the Pacific and what would a pact mean for those left out (Blum, 1982; Whelan, 1990). As Dean Rusk admitted to Warren Austin, the U.S. Ambassador to the United Nations, these were questions "to which [the State Department] does not have answers (1950)." There were so many possible options, noted Rusk: "Pacific vs Asian association, inclusion or exclusion India, Nationalist China, France, Netherlands, Latin American west coast states etc. (Acheson, 1950)." These questions would dog discussion of regional arrangements from the beginning of 1949 through to the formation

of the Southeast Asia Treaty Organization (SEATO) in 1954. In essence, they raised the thorny question of the relationship between the U.S. and its would-be Asian allies. 
By mid-1949 the crucial metaphor for describing the acceptable boundaries of the U.S. security presence in the Pacific was the idea of the "offshore island chain," a rather contrived geographical notion running from the Aleutian Islands in the north through Japan, Okinawa, and Taiwan to the Philippines. The ubiquity of the island chain metaphor clearly suggests that, beyond the Philippines, American officials did not share any sense of collective identity with the states of Southeast Asia. In a 1949 speech, Douglas MacArthur set out his strategic view of the region, saying:

The Pacific has become an Anglo-Saxon lake and our line of defense runs through the chain of islands fringing the coast of Asia. It starts from the Philippines and continues through the Ryukyu archipelago, which includes its broad main bastion, Okinawa. Then it bends back through Japan and the Aleutian island chain to Alaska $(1949,170)$.

As John F. Kennedy stated, the views of offshore presence with limited involvement in mainland Asia were shared by the U.S. military. Neither the U.S. Army nor the Joint Chiefs of Staff (JCS) wanted to keep U.S. troops in Korea (1968). Nor did they consider Taiwan to be of any great importance at that time. American officials had resigned themselves to the defeat of Nationalist forces on the island and both the CIA and the military expected Taiwan to fall by the summer of 1949 (Cohen, 1990; Clinton, 1994). Even after the outbreak of war in Korea in 1950, U.S. officials were reluctant to make a broader commitment to defending mainland Asia. Korea was, in Omar Bradley's description, "the wrong war, in the wrong place, at the wrong time, and with the wrong enemy (1951).” 
The idea of a natural role for the U.S. as an offshore presence continued to influence U.S. planning while the State Department started to advance its own ideas about establishing a bilateral network with several allies. The United States employed its bilateral strategy in the Republic of Korea (ROK), the Republic of China (ROC), and Japan in the early postwar period. It established bilateral alliances with the ROK and the ROC not only to defend against communism but also to inhibit the highly unpredictable leaders of both countries from provoking conflicts with North Korea and Mainland China that might embroil the U.S. in a larger war on the Asian mainland. To minimize the risk, the Eisenhower administration chose to exercise direct, sometimes draconian, control by creating ROK and ROC economic and political dependency on the U.S. The level of control was believed unreachable in a larger multilateral regional framework, which would have diluted U.S. material and political influence.

In the post-World War II period, the U.S. had three fundamental objectives in the Asia Pacific: contain the influence of communism, ensure access to the large Asian market, and prevent the rise of any preponderant regional power. First, the strategic environment in the Asia Pacific during the Cold War was characterized by the U.S.- Soviet bipolar confrontation and the resulting alliances that formed on both sides. The Soviet Union concluded bilateral security agreements with North Korea, China, and North Vietnam. Thus one of the main objectives for the U.S. was to contain the growth of communism in the Asia Pacific region. Joseph Nye even pointed out that U.S. regional involvement in terms of military organization, defining the impetus for the creation of NATO, was not the 
traditional U.S. regional policy but a growing involvement in the global politics of containment in the bipolar world during the Cold War period (Nye, 1971).

Second, ensuring access to the Asia Pacific market was important to U.S. economic growth. Five of America's ten largest overseas trading partners were in Asia. U.S. trade with Japan was approximately three times that of Germany, and Japan bought more from the United States than do Germany, France, and Italy combined. It was estimated that every billion American dollars of U.S. exports to the Asia-Pacific region created almost 20,000 jobs for Americans. Thus, more than 2.5 million U.S. jobs were generated by American exports to the region (Winnefeld, 1992).

The third objective was to support regional stability and reach a balance of power in the region. Some scholars, such as Renato de Castro, argue that this objective was more of a method to achieve the second rather than a strategic choice in the post-1945 era (1994). In pursuit of this interest, the United States consistently prevented the emergence of any regional power capable of dominating Asia.

There were two pillars in U.S. strategy in the region during this period of time: bilateral security arrangements and sufficient forward deployment of military forces. During the Cold War, U.S. security objectives in the Asia-Pacific were enhanced by the "San Francisco system" by which regional allies were linked to the United States, but not effectively to each other. In the 1950s, the U.S. started to expand its network of bilateral alliances, known as the "San Francisco system" or by some scholars like Victor D. Cha who calls it a 'hub and spokes' system in which the U.S. played the ' hub' and there was no apparent connection between the 'spokes'. The system was created with a series of bilateral 
treaties: the U.S.-Philippines Mutual Defense treaty of August 1951, the U.S.-Japan mutual defense treaty of September 1951, the U.S.-Republic of Korea defense treaty of October 1953, and the U.S.-Republic of China security treaty of December 1954.

These allies provided the United States with overseas military bases. In return, they were given the protection of an American-extended deterrence, economic and military assistance, and access to U.S. markets for their exports. This arrangement in providing security and economic assistance and access to the U.S. market was an integral part of the American global strategy for the containment of communism, and not a policy derived from the region itself.

The other pillar of U.S. hegemony in the Asia-Pacific was forward deployment of military power. The purpose of this was to support deterrence and to enable the United States to respond promptly and decisively to crises and contingencies, which threatened U.S. interests in the Asia-Pacific. In this region, forward military deployment was predominantly naval in nature (except in Korea where a substantial number of U.S. ground troops were deployed). U.S. naval deployments had been the traditional form of U.S. forward deployment since the start of the twentieth century. Forward naval deployment involved the stationing of naval forces in a region on a continuous basis. Forward deployments of U.S. naval power were intended to reduce the likelihood of potential conflict. This was because U.S. naval units deployed in the region were to remind regional states, which might be contemplating hostilities for whatever reason, that a U.S. presence must be taken into account in their calculations (Sheldon, 1993).) 
It is noteworthy that while bilateralism dominated U.S.'s initial Asia Pacific strategy, there was an American initiative to establish a multilateral regional pact. In the beginning of 1951, John Foster Dulles and his assistant John M. Allison pushed a 'Pacific Ocean Pact'. The initial proposal called for the establishment of a collective security agreement between the "island nations of the Pacific" (Australia, New Zealand, Japan, the Philippines, the U.S. and possibly Indonesia). Despite the numerous options available to them, the island chain notion continued to dominate their thinking as the inclusion of Taiwan, South Korea, Thailand or other Asian states on the mainland of Southeast Asia was not considered in any of the drafts (Cha, 2016).

While the Pacific Ocean Pact anticipated a nominally multilateral setting, it differed from other multilateral institutions like NATO in a number of important ways. Unlike the North Atlantic Treaty which required an automatic response by NATO members to aggression anywhere within the Treaty area, the Pacific Ocean Pact draft merely noted that in the event of an attack in the Pacific Ocean against any one of the parties each signatory would treat the attack as dangerous to its own peace and safety, which imposed much less obligation on members than the NATO treaty. Dulles also stressed that the Pact and the Japanese peace treaty were interdependent, which meant that unless the U.S. could be sure of its allies' support for the peace treaty, it would not be bound by the security pact (Macintyre, 1995). Therefore, the Pacific Ocean Pact did not have the qualitative features associated with real multilateralism.

While the Australia, New Zealand, United States Security Treaty (ANZUS Treaty) was signed in 1951 as a trilateral collective security agreement to cooperate on military 
issues in the Pacific region, the initial proposal of establishing a multilateral security alliance with more participants failed. The Pacific Ocean pact failed ultimately for a number of reasons. One of the reasons was that, as some scholars argue (Cha, 2009), Truman never really embraced the idea of the pact as a fundamental policy for the U.S., because he perceived the pact as a tool that could achieve U.S. bilateral objectives vis-àvis Japan, but not as a critical instrument for building the post-war security architecture of Asia.

Truman mentioned the Pacific Ocean Pact idea as a way to reassure allies that Japan would be embedded in a larger regional institution but he added that the multilateral pact was not a quid pro quo for bilateral control: "The United States government should agree to this [Pacific Ocean Pact] course of action only as the other nations accept the general basis on which the United States is prepared to conclude a peace settlement with Japan (Dulles, 1951, 134-135)." In internal U.S. government discussions, Dulles made clear that his primary objective was securing the bilateral peace settlement and security arrangement with Tokyo, not the Pacific Ocean Pact (Fearey, 1951). Therefore, once Dulles secured the bilateral control of Japan through a series of five U.S.-Japan annexes to the peace settlement, signed by diplomats John Allison and Sadao Iguchi in February 1951, his interest in the Pacific Ocean Pact waned.

Therefore, even though the U.S. promoted policies like the Pacific Ocean pact to establish a multilateral setting, what dominated U.S. strategy in the Asia Pacific was the bilateral "San Francisco System". The U.S. role in that post WWII Asia Pacific was unique in the sense that it was a result of immense asymmetry between the U.S. and its bilateral 
allies in the region. Unlike in Western Europe where the U.S. allies were two powers that emerged victorious from WWII, the main ally that the U.S. had in the Asia Pacific was its former enemy, Japan, which had been severely devastated by the war. Other allies such as the Philippines, Thailand, Taiwan and, to a certain degree, Australia and New Zealand, were relative political-military weaklings that were not in a position to deal with the U.S. on an equal footing either. As a result of this asymmetrical relationship, as Miles Kahler noted, American hegemony took the form of suzerainty (1991).

Therefore, the U.S. pursued a network of bilateral alliances in the Asia Pacific instead of a multilateral alliance such as the institutional framework of NATO it established in the Europe. There were several reasons behind U.S. preference for bilateralism in the post World War period. As Victor D. Cha argues, power relations determine a country's preference for alliance type (2009/2010). For partners with asymmetric capabilities, bilateral alliances can become powerful instruments of control by the one that is stronger. In addition, the smaller allies of the U.S. in the Asia Pacific all depended heavily on the U.S. to provide security and prestige benefits, which gave the U.S. a great deal of leverage.

In the 1980 s and early 90 s, the region started to witness the growth of emerging economies in the region. Lingering against the backdrop of the rapidly developing economies of the region was the specter of closed regionalism. Indications of this specter of closed regionalism were the initial Japanese idea of a Pacific Community in the 1980s and the Malaysian proposal for an East Asian Economic Caucus (EAEC) discussed in the previous section. East Asian economic growth was thriving in a regional environment free from any multilateral economic and political structures that existed in Europe. 


\section{Post Cold War: from hegemon to regional "balancer"}

During this period, U.S. power was in relative decline in the Asia Pacific from military, economic, and political aspects. The disappearance of the Soviet Union eroded the rationale and value of the U.S. as a "security guard" in the region. For Asian countries, America was no longer a reliable protector in the absence of the Soviet threat. In the 1980s, Asian countries began their military modernization programs driven by their rapid economic growth. Although the U.S. balancing role was still appreciated in the region after the Cold War, the increasing military capabilities of Asian states implied a relative decline of U.S. power in the military realm.

In addition, the rapid growth of Asian economies challenged the preeminent economic and political role of the U.S. in the region. Contrary to the serious domestic fiscal and social problems the U.S. faced in the early 1990s, Asian economies had boomed from the 1980s. In 1965, Asia Pacific economies (including Australia and New Zealand) together totaled only $1 / 4$ of the U.S. GNP, but they matched the U.S. GNP in the early 1990s. The share of U.S. international trade in the Asia Pacific was also gradually decreasing. For example, the proportion of South Korea's trade with the U.S. in its total trade fell from $36 \%$ in 1970 to $27 \%$ in 1990 . The proportion of Japanese exports sold in the U.S. was $40 \%$ in the 1980 s while it decreased to $28 \%$ in 1990 . Intra-regional trade in Asia had become the driving force of rapid economic growth in Asia.

The economic success also gave political confidence to the Asian countries, and some Asian states began to question the U.S. free-market economic model and liberal political ideology. The regional newly industrialized economies, such as South Korea, Taiwan, and 
Singapore, believed that the export-oriented, state-directed, semi-protected variant of the market-oriented development model they adopted was a better way to achieve economic development than what America promoted. Countries such as Singapore, Indonesia, and Malaysia then further questioned the compatibility and applicability of U.S. liberal democratic ideology in the region. The intellectual clash between "Asian values" and Western democracy manifested Asia's political challenge to U.S. primacy in the 1990s.

Rising competitors, such as Japan, challenged U.S. dominant power in the region. Japan was widely perceived as the next powerhouse replacing the U.S. in Asia. In foreign investment, Japan exceeded the total U.S. foreign investment in the region and took a leading share in almost all countries. In international aid, Japan also replaced the U.S. as the predominant provider in Asia in the early 1990s.

During this stage, the U.S. recognized the increasing importance of the Asia Pacific region, especially in the economic sphere. In 1991, President George H. W. Bush outlined his major foreign policy goals toward Asia in a speech to the Asia Society in New York. He noted that the U.S. was deeply committed to the Asia Pacific, a region of overwhelming economic importance as the Asia Pacific had the world's fastest growing rate of economic expansion and was the largest trading partner of the U.S. It was repetitively emphasized in governmental records that the economic future of the U.S. lay in the Asia Pacific region (1993). The awareness of the importance of the Asia Pacific at the administration level led to a changing active policy towards regional cooperation. As stressed in a congressional meeting, "given the increasing level of U.S. exports destined for the Asia Pacific region, 
economic cooperation between countries in the region, including the U.S. was critically important (1993)".

The United States pursued its vision of a new world order in the Asia-Pacific through diplomatic and military means. In the realm of diplomacy, it consistently engaged the economically more advanced Asian states in a series of diplomatic tussles intended to open their markets and to persuade them to assume more responsibility for a stable regional order. This was clearly reflected in President Bill Clinton's visits to South Korea and Japan in 1993. While asking those two countries to open their markets further, President Clinton used those occasions to articulate America's agenda for the region: a more prosperous community through open markets and open societies; and a more secure community through the maintenance of U.S. alliances and forward military presence, and support for the U.S. military presence and non-proliferation policies (Christopher, 1993).

Supplementing U.S. diplomatic initiatives for Washington's vision of a regional order was its military presence in the region. U.S. commitment to remain a military power in the region was reiterated by President Clinton in his July 1993 speech to the South Korean National Assembly. As announced by several senior U.S. officials, the Asia-Pacific region was considered "one of the most relevant to the rebuilding of the U.S. economy", thus, there was a need to assure that it remained a stable and peaceful region, made possible only by a U.S. military presence. The United States Pacific Command (PACOM) Commander noted: "Economic, political, and security engagement by this Nation [U.S.] in the AsiaPacific and Indian Ocean region since the end of the Second World War has been a dominant factor in its emergence as one of the engines of global growth and a major market 
for our exports. The forward deployment of U.S. forces in the region contributes significantly to maintaining stability, enhances our diplomatic influence, and promotes an environment conducive to the growth of our interest there. Regional stability, however, is not an end in itself. By maintaining regional stability through forward deployment, the United States can influence regional developments to suit its interests. Asia-Pacific states contemplating altering the status quo would have to take into account America's naval presence (Chan, 2013, 176)".

The U.S. forward presence provides indisputable definition of the broader spectrum of America's regional interests. Should this presence diminish to a point where regional states no longer deem American power sufficiently engaged and committed, then the United States would no longer be able to wield influence in the Pacific Rim. Commensurate with the region's strategic importance under such circumstances, regional states would increasingly define their political and strategic goals without equivalent regard for and attention to American interests. In such a scenario, therefore, a lead American role in shaping the Pacific Rim's future could no longer be assured (Winnefeld, 1992). It was no longer in the U.S. interest to maintain the same level of military presence in the region as during the Cold War. A reduction of U.S. forces was a natural result of the end of the Cold War in the Asia-Pacific and to meet the need of reducing defense budget.

As discussed above, there had been a dramatic change in the regional environment where the U.S. was seeking to maintain bilateral security arrangements and sufficient forward deployment of military forces as pillars of its Asia Pacific strategy. Asymmetrical relations were challenged with the economic development of its allies and increasing 
interdependence among them. Deployment of military forces was no longer perceived as strong protection or as a threat to these countries. All these changes forced the U.S. to adjust its cold war balancing strategy in both economic and security realms and led to a change of attitude on the part of the United States towards multilateralism. It adopted the role of a "balancer" instead of a "regional hegemon". Given the deepening economic interdependence between the U.S. and Asia, it was imperative that the U.S. play a "balancer" role to maintain regional order. Because of its geographical distance from the region, the balancing role was also more easily accepted by the regional powers.

The traditional bilateral alliances became insufficient for the U.S. to deal with postCold War strategic challenges, including Japan's and China's rise. As discussed before, multilateralism was not a preferred agenda in U.S. decision making towards the Asia Pacific during the Cold War period. However, in the post-Cold War area, with the changing conditions that the U.S. was facing in the Asia Pacific, multilateralism became a necessary supplement of the U.S. bilateral "San Francisco system" for effective engagement in the Asia Pacific. The U.S. "balancer" role was challenged by the regional practice of multilateralism, as U.S. traditional preeminent military power could not convert equally to institutional power. The U.S. faced institutional challenges and resistance from both ASEAN states and China when it attempted to push its agenda in the region. Therefore, U.S. readjusted its policy towards the Asia Pacific and began to exercise its "balancer" role within the regional institutions during the post-cold war period.

\subsubsection{U.S. Foreign policy towards regional institutions in Asia Pacific}

As discussed in the previous section, the U.S. before the end of the Cold War did not 
favor multilateralism, but rather established a bilateralism-dominated policy towards the Asia Pacific region. Although the U.S. proposed the Pacific Ocean Pact, the real intention was to secure its bilateral alliances in the Asia Pacific region. However, the changing power disparity between the U.S. and its allies in the context of the economic miracle in the 1980s and the collapse of the Soviet Union forced the U.S. to reconsider its position vis-à-vis its Asian allies and go beyond its tradition relations under the 'San Francisco system'.

After the Cold War, the U.S. began to show selective enthusiasm for participating in regional multilateral institutions in the economic and security realms by participating in APEC and ARF. The U.S. did not take serious initiative in the first stage, initially responding indifferently to the institution-building proposals, but became more active in pursuing multilateral cooperation in the later stages. This section traces the historical transition of U.S. foreign policy to multilateral regional institutions in the Asia Pacific region and explores the rationale behind this change.

During the pre-APEC period, the U.S. interest in Asia-Pacific economic cooperation gradually emerged, first at a private level, and then later at the governmental level. However, such emerging interests did not lead the U.S. either to conceive proposals or take particular initiatives for capitalizing on the concept of regional economic cooperation. Rather, it remained largely passive; some scholars even describe it as opposed to the initiatives from other powers in the region such as Japan and Australia.

This characterization of the U.S. attitude towards regional institution held valid for the case of U.S. policymaking toward the creation of APEC, which has grown to be the largest 
regional institution in the economic realm. When Japanese policymakers describe the creation of APEC as "a historical development in the region" at the inaugural meeting of APEC in Canberra in 1989, their counterparts in the U.S. government, in contrast, appeared a little more restrained in their perception of the institution. Secretary of State James Baker stated: “ I don't know whether or not I would use the term 'historic' yet. But I think this has the potential to qualify for that type of description $(1989$, p. 4). Baker's notion of "potentially historic" reflected the U.S. attitude toward the creation of APEC and epitomized the twisted path that U.S. policymakers had gone through in the course of creation of APEC.

As discussed in the previous chapter, the creation of APEC started from an initiative of Japan and Australia. Originally, the Australian and Japanese proposal did not include the U.S., a target rather than a partner of the proposed regional cooperation in Asia Pacific at that time (Yochi, 1995). However, Australia and Japan had to modify their proposals given the strong opposition from both ASEAN countries and the U.S. Even though U.S. held reserved attitudes towards APEC, being left out of a multilateral regional institution was not in the interest of the U.S. either.

In line with the changing strategy of the U.S. towards the Asia Pacific, U.S. policy towards APEC adjusted in the 1990s. The U.S. became more active in pursuing multilateral cooperation though APEC. Starting from the Bush Administration, the U.S. warmed up its interest in APEC. Secretary Baker once said that growing "intra-Asian and trans-Pacific trade and investment provide the broad common interests on which to build the Pacific 
community... APEC was as much a hallmark of our engagement in the region as are our security ties (Lasater, 1996, 5).”

The enthusiasm grew during the Clinton administration. The Clinton administration set domestic economic renewal as its top policy priority. More than ever before, U.S. domestic prosperity depended on its engagement in the global economy. Increasing exports was one of the best options for the U.S. not only to reduce the trade deficit but also to create jobs. Thus, under these circumstances, there was no region more important to the U.S. than the Asia Pacific region with its fastest growing economy. Given America's increasing trade deficits with key Asian Pacific countries, a strong multilateral trade forum that could help reduce trade barriers was urgently needed by the U.S. The U.S. intention was to shape a Pacific community in a spirit of consensus and partnership through APEC. "This community will promote free markets and therefore prosperity for all, security through regional dialogues with potential enemies, and reduce tensions by talking to each other directly rather than building up blocks against a common threat (1993, p. 8).”

APEC thus became an important tool of institutional balancing for the U.S. for the following reasons: First, the U.S. economy was technologically advanced, productive, and competitive. Economic liberalization and free trade benefited the U.S. economy more than other members in APEC. The multilateral arrangement provided by APEC could facilitate economic liberalization through reducing transaction costs that the U.S. had to pay for bilateral negotiations with individual countries. Second, the institutional framework provided the U.S. an opportunity to work with other countries in the region to pressure countries like Japan to open its domestic market in a less offensive and more effective way 
than imposing pressure through a bilateral venue. Third, APEC provided the U.S. another platform to negotiate with nondemocratic countries like China. The U.S. wanted to retain ties with China and pushed China to address a number of issues, such as human rights and China's protective trading policies. The U.S. had tried bilateral tools but was not very successful. It also tried to push these issues through multilateral institutional frameworks, such as the GATT, but China would not be ready for admission for a long period of time. Therefore, a regional organization such asAPEC, in which China tried to play as an active participant, provided the U.S. an effective platform to push negotiations with China.

If the U.S. treated APEC as an institutional means to increase trade by opening Asian markets, U.S. policy toward ARF was to lower the costs of managing regional security. As in the case of APEC, due to its embedded commitments to bilateral alliances and preponderant U.S. military might, the U.S. was passive towards ARF in its initial stage. When Australia and Japan proposed regional security dialogues in 1990 and 1991, the U.S. attitude was "lukewarm, if not hostile (Smith, 1997)." In 1990, assistant Secretary of State for East Asia during the Bush Administration, Richard Solomon, stated that initiatives for multilateral security dialogues were "solutions in search of a problem (Smith, 1997)." The 1990 East Asia Strategic Initiative (EASI) made it clear that "U.S. interests are best served by continuing to work within the context of the bilateral defense relationships we have developed over years (p. 22)." Even in the 1992 EASI, multilateralism was not mentioned; the U.S. saw itself as "the key regional balancer" and its forward-deployed presence "has underpinned stability in East Asia and helped secure its economic dynamism (1992)." 
However, as illustrated in the previous section, the end of the Cold War brought comprehensive change to the security environment of the world. The changing security dynamics of the Asia Pacific pushed the U.S. government to revisit its bilateral military approach. On the other hand, in the context of U.S. domestic economic recession and overseas military withdrawal, Asian countries started to consider how to prepare themselves for a peaceful environment without the presence of the U.S. military. In 1993, Japan's Prime Minister Kiichi Miyazawa urged the Asian and Pacific nations to "develop a long term vision regarding the future of peace and security for their region (Leifer, 1996, 27)." Multilateral security institutions were once again on the table. Meanwhile, the U.S. began to embrace the idea of multilateral security institutions to complement bilateralism and lower the costs of U.S. engagement in Asia.

ARF provided the opportunity for the U.S. to fulfill two goals. First, U.S. participation in ARF reconfirmed its identity as an integral Asia Pacific power and helped it justify its remaining military presence in the region. The multilateral nature of ARF increased the role of middle and small powers' voices in regional affairs and reduced regional fears and worries about a U.S. preponderance of power. Second, ARF provided the U.S. a platform to participate in dealing with new security threats in the Asia Pacific that re-emerged after the Cold War. The antagonism between the U.S. and the Soviet Union during the Cold War suppressed many regional conflicts and problems, such as territorial disputes among some Southeast Asian countries and maritime disputes over the South China Sea. After the Cold War, these old problems re-emerged. The U.S. military presence and previous bilateral 
military alliances had their limitations in dealing with these regional problems as these problems required not only bilateral, but also multilateral approaches to solve them.

In the late 1990s, the U.S. attitude toward ARF experienced a downturn mainly due to the 1997 Asian financial crisis. The collapse of the East Asian economic miracle not only boosted U.S. confidence in sustaining its primacy in the region, but also increased the leverage of U.S. in dealing with challenges from countries that were shattered by the crisis. The utility of ARF in reducing the cost of the U.S. in managing regional security was deflated too because of the malfunction of ARF during the East Timor crisis. Instead, the U.S. started to strengthen its bilateral alliances with Japan, South Korea, and Australia, as well as to expand its military access to some ASEAN countries. Thus, during the second part of the 1990s, there was a revitalization of bilateralism in U.S. strategy toward security issues in Asia Pacific.

After the September 11 tragedy, U.S. policy interest in ARF was strengthened again. Since then, the U.S. has devoted its participation in the institution to promoting antiterrorism as the top issue in ARF and use ARF as a platform to expand its global campaign against terrorism. Even though U.S. anti-terrorism cooperation with regional powers was still largely of a bilateral nature, such as U.S. military aid to ASEAN countries like the Philippines, it is clear that despite the low efficiency of ARF, the U.S. still actively participated in this multilateral format and treated it as complementary to its bilateralismbased strategy toward the Asia Pacific.

However, the absences of Secretary of State Condeleezza Rice at ARF's 2005 and 2007 meetings provoked criticism from other member states. As a result, when Obama 
became president, U.S. attendance and participation in ARF was expected as proof of America's desire to improve relations. Recognizing this, Secretary of State Clinton attended the 16th Annual ARF meeting, held on July 23, 2009, in Thailand, as her first ARF meeting. In the Roadmap, there were some main components that the U.S. gave great focus and attention to and these included the "promotion and protection of human rights". It called for the establishment of a human rights body through the completion of its Terms of Reference by 2009 and encouragement between it and existing human rights mechanisms and "promotion of principles of democracy". It also called for promoting an understanding of the principles of democracy among ASEAN youth at schools at an appropriate stage of education (The ASEAN Secretariat, 2009). Both missions provided the U.S. an opportunity to foster U.S.-ARF relations and to help member states to accomplish these goals.

Meanwhile, two key multidimensional threats and challenges affecting the Obama Administration arose during the ARF meeting: the Myanmar and South China Sea issues. During the Bush Administration, U.S. interaction with Myanmar was restricted as America imposed economic sanctions on the Myanmar government. In 2009, the Obama Administration called for a new policy of both engagement and sanctions. It hoped dialogue with the Myanmar military junta could yield positive results. The ARF meeting thus provided a great opportunity for the administration to garner ARF leaders' support for its new policy towards Myanmar. Besides the Myanmar issue, the South China Sea was in the section analyzing multi-state issues. As discussed in China's policy, the South China Sea was - and continues to be - a hotly contested topic between some ASEAN members 
and China due to their various claims in the Spratly Islands. ASEAN members wanted U.S. backing in the South China Sea dispute. It was also in the interest of the U.S. to cooperate with relevant ASEAN members in reaching a Regional Code of Conduct in the South China Sea to contain the growth of China in the region.

Through years of participating in ARF, the U.S. has actively applied its institutional balancing strategy to fulfill its strategic goals in the region in the following ways: First, the U.S. tried to shape the agenda of the institution to its own interests. The U.S. has highlighted the importance of the non-proliferation issue in ARF. In the 1994 ARF meeting, Secretary Christopher first raised the non-proliferation issue and discussed it intensively with China. In addition, to target the North Korean nuclear program, the U.S. actively proposed a Northeast Asian Security Forum as the counterpart of ARF's focus on Southeast Asian affairs. By doing that, the U.S. hoped to use multilateral security dialogues and institutions to constrain North Korea's assertive behavior (EASI III, 1995). Even though the U.S. plan did not materialize due to opposition from China and North Korea, it laid the foundation for the later series of Four Party Talks and Six Party Talks.

Second, the U.S. has tried to set rules to constrain the growing sway of China. As analyzed before, China used ARF as one of the main venues to strengthen its ties with the ASEAN countries and the ASEAN states also use ARF as a major means to engage China. For instance, regarding the three phases of ARF, the U.S. hoped to move from confidencebuilding measures to preventive diplomacy and conflict resolution. China and some ASEAN states worked to oppose the U.S., because they were worried about the legalization and institutionalization of U.S. endeavors. However, the U.S. successfully worked with 
some ASEAN states in pushing for defense transparency in the region. Because of the absolute U.S. military advantage and its own transparency, defense transparency would benefit the U.S. more than other member countries, especially China (Goh, 2004).

While the U.S. has increasingly exercised institutional balancing strategies in APEC and ARF, the U.S. was passive towards APT (ASEAN Plus Three) and the later EAS (East Asia Summit). Exclusive institutional balancing against the U.S. is evident when examining the interaction between U.S. and these two multilateral institutions. APT and EAS can be seen as Asia's institutional balancing behavior by which the U.S. was deliberately excluded. Originally, the establishment of these institutions was mainly because of regional resentment and frustration towards the U.S. due to its lukewarm attitude and policy during the Asian economic crisis. There were two incentives behind this exclusive institutional balancing act: first, it could increase regional economic consolidation and reduce economic dependence upon the U.S.; second, the deliberate exclusion of the U.S. might pressure the U.S. to adjust its assertiveness towards it Asia Pacific partners.

The U.S. was aware of the strategic purposes of APT and EAS. However, for the U.S., the economic and crisis had revealed the economic political weakness of Asia's multilateralism. In addition, the fragile relations and deep suspicions among Asian countries also weakened the effects of these Asian-inclusive institutions on U.S. interests. Politically, the economic crisis soured bilateral relations among ASEAN states and troubled relations between China and Japan as both struggled for the leadership position in these institutions. 
However, during the Obama administration, U.S. policy towards EAS was changed. In 2010, Secretary Clinton attended the EAS meeting as a guest of Vietnam. At the Summit, Clinton acknowledged the importance of the EAS and her attendance paved the way for U.S. membership in the EAS in 2011. Besides breaking the exclusion, to counter exclusive institutional balancing acts in the region, the U.S. focused on strengthening bilateral economic and political relations with ASEAN through a series of initiatives, such as "Enterprise for ASEAN" in 2002 and "ASEAN-U.S. Partnership" in 2005, and promoting another non-Asian only multilateral agreement with Asia-Pacific countries such as the Trans-Pacific Partnership (TPP).

The TPP is a regional free trade that agreement aims to deepen regional economic integration in the Asia-Pacific, create jobs, and foster closer trade and investment ties. The TPP negotiations were undertaken by twelve members and were successfully concluded on 6 October $2015 .{ }^{6}$ On the whole, the Obama's administration recognized the importance of APEC and the trade and investment liberalization it sought to foster for future economic growth and prosperity. Besides increasing its participation in APEC, another goal of Obama's trade policy was to become an active member of the TPP Agreement to increase experts and employment rate (The Department of State, 2011). As economic growth slowed throughout the industrialized countries, economists have recognized that much of the world's GDP growth was being generated in the Asia-Pacific region. While the U.S. has long-standing commercial ties in the region, some argue that U.S. was still being locked out of Asia's emerging trade architecture features with a number of ongoing and

\footnotetext{
${ }^{6}$ The Twelve TPP members are Australia, Brunei, Chile, Canada, Japan, Malaysia, Mexico, Peru, New Zealand, Singapore, the United States and Vietnam.
} 
overlapping bilateral and multilateral trade negotiations, including the ASEAN-led Regional Comprehensive Economic Partnership, the trilateral China-Japan-Korea trade talks (2013).

In recent years, the U.S. gave more focus to the TPP as Obama's administration hoped that it would help him to achieve the goals of doubling U.S. exports, create more markets for U.S. products, and generate more jobs for Americans (Carroll, 2011). Within the TPP, the U.S. tried to shape the negotiation agenda to its economic interests, such as promoting connectivity to deepen the links of U.S. companies to the emerging production and distribution networks in the Asia-Pacific, making the regulatory systems of TPP countries more compatible so that U.S. companies could operate more seamlessly in TPP markets (Office of the U.S. Trade Representative, 2010).

For the U.S., the TPP was able to serve not only strategic but also economic purposes. On the strategic front, the TPP serves a number of U.S. interests. Through its participation in the TPP negotiations, the U.S. sought to reassure its partners of its commitment to maintaining a peaceful and prosperous Asia-Pacific region. The agreement represented a U.S. rebalancing strategy toward Asia through regional institutions. The TPP was to be an important institution for the U.S. to exercise exclusive institutional balancing against China. Being excluded from the TPP would not only limit China's access to the market, but also would constrain it from participating in new rounds of rule-setting processes. As a leading member of the TPP, the U.S. hoped to promote the TPP as a vehicle for establishing standards on new and emerging 21 st trade issues, such as e-commerce and investor-state disputes, and set a template for future trade agreements within and beyond Asia through 
the TPP negotiation. Being excluded from the TPP, China did not have a chance to participate in these negotiations and make a case for its own stand on certain issues, such as regulation of state-owned enterprises, that were discussed during the TPP negotiation.

\subsection{Japan's Policy Analysis}

This section examines Japan's foreign policy towards the Asia Pacific by historically unfolding Japan's regional policies and their implication for understanding Japan's regional strategy. This section examines external variables, such as changing power structure, and internal variables, such as bureaucratic conflict, which triggered three waves of Japan's regional policy: the first phase marked by constrained bilateralism with the U.S. and initiation of regional multilateralism; the second phase marked by expanded bilateralism with other Asia Pacific countries; and the third phase marked by maintenance of bilateralism and promotion of multilateral activism. After examining Japan's regional policy, this section further analyzes Japan's policy towards specific regional institutions and agreements: such as Asia Pacific Economic Cooperation (APEC), ASEAN Regional Forum (ARF), ASEAN Plus Three (APT), and East Asia Summit (EAS).

There has been a debate over the nature of Japan's foreign policy. The most popular interpretation claims that Japan has been a "reactive state" (Calder 1988; Pyle 1989), as Japan has tended to react to the pressures, changes, and demands of the external environment and rarely initiated its own foreign policy. Passive involvement in regional and international affairs is a key feature of Japan's policy, according to this interpretation. Some even argue that in the 21 st century Japan still has not yet developed its own grand strategy. This group of scholars usually supports their argument by emphasizing Japan's 
reliance on U.S. security protection and the constraints, both external and internal, that Japan has faced after World War II (Hirasawa, 1975).

This section by unfolding Japan's Asia-Pacific policy questions this prevailing perception of Japan's foreign policy in analyzing Japan's Asia-Pacific policy and claims that both domestic and external variables have served as determinants of Japan's regional policy since the end of WWII. Acknowledging the influence of the U.S. on Japan's foreign policy making, this section notes that Japan's own initiatives have been understudied. Even though Japan did not adopt a proactive policy towards the Asia Pacific immediately after World War II, there were several initiatives to promote Japan's interests and agenda in this region within Japan's government that have been overlooked. Therefore, this section seeks to examine these overlooked initiatives and outline Japan's regional policy in a new way.

\subsubsection{Japan's Regional Policy}

By historically examining Japan's policy and involvement in regional affairs, this research divides Japan's regional policy into three phases: 1) Phase I: 1950s-1970s, during which Japan started to form its postwar regional policy; 2) Phase II: 1980s-1990s, during which Japan started to use economic diplomacy to ameliorate its relations with other Asian countries; 3) Phase III: $21^{\text {st }}$ century-present, during which Japan embraced a proactive multilateral regional policy and has competed with China and the U.S. to be a regional leader.

\section{Phase I: 1950s-1970s}

After World War II, the Yoshida Doctrine, which softened Japan's political interests 
and prioritized its domestic economic development, had a prevailing influence on Japan's foreign policy. Because Japan had been heavily destroyed in World War II, the Prime Minister, Yoshida Shigeru, adopted a mercantilist policy, which risked Japan's integrity and political normality by becoming a subordinate partner of the United States, in order to focus on its economic recovery after WWII.

One of the key elements of this doctrine was pacifism. Japan restrained itself from developing an independent security or a strong army other than a small-scale Japanese SelfDefense Force (JSDF). The Constitution of Japan, which came into effect on 3 May 1947, has been known as a pacifist constitution. As the Preamble of the Constitution proclaims:

"We, the Japanese people... resolved that never again shall we be visited with the horrors of war through the action of government... We... desire peace for all time... and we have determined to preserve our security and existence, trusting in the justice and faith of the peace-loving peoples of the world"7

Along with the Preamble of the Constitution, Article 9 states:

"Aspiring sincerely to an international peace based on justice and order, the Japanese people forever renounce war as a sovereign right of the nation and the threat or use of force as means of settling international disputes.

\footnotetext{
7 Constitution of Japan is available at Prime Minister of Japan and His Cabinet's website, http://www.kantei.go.jp/foreign/constitution_and_government_of japan/constitution_e.html
} 
In order to accomplish the aim of the preceding paragraph, land, sea, and air forces, as well as other war potential, will never be maintained. The right of belligerency of the state will not be recognized."

In very basic terms, Article 9 is a unilateral renunciation of the use of force under any circumstances for the settlement of disputes and prohibits Japan from any war potential. Through this renunciation, some scholars argue that Japan lost its identity as a 'normal' independent nation in international affairs, as Japan lacks the capability of wielding military force as a viable instrument of diplomacy (Fukushima, 1999).

Besides being constrained by the absence of a strong military force, Japan's regional policy making was also inhibited by two other constraints. One constraint was internal, a legacy of defeat and occupation, which led to a sense of vulnerability, and contributed to the fragmentation and polarization of Japan's domestic politics.

Another constraint was the external environment. After Japan's imperialist invasion of its neighboring countries, the regional and international environment that Japan faced was hostile. Thus, Japan's policy makers perceived Japan to be extremely vulnerable and limited in foreign policy options. The political-security dimension was reflected in the tripolar structure involving the United States, the Soviet Union, and the People's Republic of China. Thus, pacifism was promoted to help Japan to remove any suspicions of a Japanese threat to neighboring countries, especially to China and South Korea, and also to the United States. Economically, Japan's sense of vulnerability rested on the fact that as an island

\footnotetext{
${ }^{8}$ Ibid.
} 
country with limited arable land Japan depended on imports for food, fuel, and virtually all essential industrial raw materials, and had a corresponding dependence on fair access to foreign markets for its exports.

Due to these constraints, Japan strived to establish a strong bilateral relationship with the U.S. Under the Mutual Defense Treaty between Japan and the U.S., the U.S. committed to help defend Japan if Japan came under attack and the U.S. was able to establish bases and ports for U.S. armed forces in Japan. When the 1951 treaty entered into force, it seemed like a win-win situation for both Japan and the U.S. For Japan, allying with the most powerful state ensured its security and was an ideal condition for its economic development. For the U.S., with this treaty, the U.S. ensured its presence in East Asia.

Besides the dominance of this bilateral relationship in Japan's foreign policy, there were several initiatives to promote multilateralism in the Asia Pacific among Japanese leaders. Takeo Miki, like Yoshida, perceived that the lack of resources and markets led to Japan's vulnerability. However, unlike Yoshida's U.S.-centered policy, Miki proposed an Asia-Pacific -centered policy and believed that Japan needed access to markets and raw materials in Asia. In 1948, Miki noted that Japan should play a sustaining role in Asia's economic development, as there would be no future in Japan if Japan were isolated from Asia, nor would Japan have a future if Japan could not play a bridging role between the developed West and developing Asia (Takenaka, 1994).

Even though Miki started to propose his Asia-Pacific-centered diplomacy from the late 1940s, it was not widely accepted in the Diet as it diverted from Yoshida's U.S.-Europe centered diplomacy. Another reason for the Diet's reluctance is the fact that markets in Asia 
after the war were not big enough to absorb Japanese products in comparison with markets in U.S. and Europe. However, things changed gradually in the 1960s. The Asia-Pacific policy became possible after Miki's long-held diplomatic beliefs were linked to Japan's high economic growth and a changing political environment in which the U.S. was struggling in the Vietnam War and the other Asian countries were recovering economically. In 1966, in his speech, 'Light and Shadow of the Pacific Era', Miki noted:

"The countries bordering on the Pacific are now fully aware of the fact that they belong to the Pacific region and, as such, are increasingly aware of the common ties of destiny that bind them...there has been a growing trend in Asia, on its initiative and cooperation, to tackle the Asian problem... The cooperation of the Pacific nations in these encouraging developments in Asia has come to be most important (1966)."

Miki's Asia-Pacific policy basically included two initiatives in the Asia Pacific. One was about fostering regional cooperation through multilateral institutions. Another aspect was about the provision of aid to developing Asian countries. The first aspect was reflected in the participation in the Asian Development Bank, the Ministerial Conference on Southeast Asian Development, and the Asia-Pacific Council (ASPAC). Miki noted that the Asia-Pacific region would eventually create a new institution, which the other regions would not be able to emulate (Sekai, 1967). The second aspect concerned trade liberalization and included the possibility of a Pacific Free Trade Area (PAFTA).

While Miki was outlining the basic framework of an Asia-Pacific multilateral approach, the Ministry of Foreign Affairs (MOFA) was working to embody the policies. MOFA organized senior official meetings that focused on two plans for realizing the Asia- 
Pacific policy. One plan was to establish the Ministerial Conference on Southeast Asian Development. The other was to create PAFTA among the nations in Asia Pacific. The plans were integrated with three areas to implement the Asia-Pacific policy: economic and technical cooperation; an institution for expanding trade; and regional security (Nihon Keizai Shimbun, 1967).

In addition, Miki reached out seeking partnership with Australia to further promote his idea of regional cooperation. As Guillain noted, the reason why Japan strived to promote its idea of regionalism to Australia instead of the U.S. was because Japan did not want to get involved with U.S. Far Eastern strategy and wanted to form a multilateral association in which the weight of the U.S. would be counterbalanced by that of other members (1970). Miki organized two meetings with Australia at senior official and ministerial levels to push Japan's initiative of working with Australia to establish a multilateral association to stimulate regional economic development through multilateral cooperation. These meetings marked the initial steps in the Japan-Australia partnership in economic institution building in the Asia-Pacific region, which later took form as APEC (Terada, 1998).

\section{PHASE II: 1970s-1990s}

Due to Japan's increased economic power, it began to re-examine its foreign policy and take active measures to assert itself in the international community as a "normal" independent country. In 1972, Japan's export-led growth model, which relied on the U.S. open market and the Bretton Woods liberal economic order, successfully led Japan's economy to surpass that of Great Britain and become the second largest economy. With 
the accumulation of its economic wealth, the Japanese government then devoted itself to transforming its economic potential into political influence.

However, Japan's promotion of regional multilateralism was not smooth during this period. The growth of Japan's 'Asia Pacific' concept along with its re-emergence as a great power increased concern from other Asian countries. Japan's attempt to build a regional institution led to criticism from Asian countries that Japan was attempting to create a second version of the Greater East Asia Co-Prosperity Sphere. As Tsuneo Iida, the deputy of Prime Minister Ohira's Pacific Basin Study Group noted:

“In discussing Prime Minister Ohira's concept in the late 1970s, we were often told by Southeast Asians at that time that the concept amounted to the second Greater East Asia Co-Prosperity Sphere or that there was surely something like the Co-Prosperity Sphere concealed behind the rationale (Terada, 1998)."

As revealed by Terada, there was an idea within the Japanese government that Japan should keep a low profile in regional institution building. Instead of taking the lead, Japan should let Australia take the initiative so that Japan could avoid triggering resentment from other Asian countries (1998).

The stagnation of regional institutional development during this period was also because of Australia's reluctance to take the lead in promoting regional multilateralism. Australia did not want to damage its relations with Europe, especially with its significant trade partner Great Britain, by joining an Asia-Pacific exclusive regionalism. Even though bilateral trade grew substantially between Australia and Japan, as Prime Minister Harold 
Holt noted, Australia and Japan were "still only at the beginning of what we confidently believe to be expanding association in trade and matters of mutual concern (1967)". Therefore, Australia was very cautious about Japan's proposal to establish Asia-Pacific regional institutions during this period.

Japan's domestic bureaucratic conflict between the Ministry of International Trade and Industry (MITI) and the Ministry of Foreign Affairs (MOFA) also influenced Japan's attitude towards regional multilateralism. While MITI actively advocated economic cooperation and regionalism through APEC from an economic perspective, MOFA was deeply concerned about the political impact of Japan's proactive policy toward regionalism, which backfired in the 1970s as reflected in protests in Asian countries. Therefore, Japan's role shifted from initiator to promoter behind the scene in the process of establishing regional institutions like APEC.

For Japan, with a constrained regional multilateralism, Japan's "normal" policy goal was most likely to succeed in the economic area. Therefore, Japan has advocated the "flying geese model" since the 1970s. In this model, Japan was placed as the "lead goose", which was followed by other Asian countries. Because of Japan's remarkable economic miracle, its export-led growth model with government intervention provided Asian countries an alternative to the U.S.' market-driven capitalist development model. In 1987, the Ministry of International Trade and Industry (MITI)'s New Asian Industry plan emphasized the "flying geese model" as a tool for Japan to assert its influence over Asia (Funabashi, 1995). Although Japan's major trading partners in the 1960s and early 1970s 
were mainly the U.S. and European countries, Asia gradually increased its importance to Japan as a trading and investment partner in the late 1970s and 1980s.

In addition, Japan started to exercise economic diplomacy to establish and strengthen its bilateral relationship with Asian countries through preferential trade agreements and Foreign Direct Investment (FDI). The rise of the yen after the Plaza Agreement in 1985 encouraged Japanese manufacturers to move their factories offshore through direct investment because it was cheaper to produce cars and electronics in low-wage developing countries such as Southeast Asia and China. The strong yen then boosted Japan's FDI outflow to Asian countries and ameliorated its bilateral relations with Asian countries.

\section{PHASE III: 1990s to present}

Japan's foreign policy in this period has been widely described as a proactive foreign policy. Even those who argued that Japan was a reactive state noticed Japan's intention since the 1990s to adopt a more autonomous diplomacy. The end of the Cold War brought an end to the bipolar system dominated by the U.S. and the Soviet Union. The world then transformed into a multipolar geopolitical structure, in which Japan itself with its exceptional economic development had the potential to become a pole. This transformation of the power structure urged Japan to rethink its asymmetrical relation with the U.S. and its position in the new world structure. However, even before the collapse of the Soviet Union, there were several events that had pushed Japan to readjust its economics-based diplomacy. 
On August 2, 1990, the Gulf War Crisis erupted with Iraq's invasion of Kuwait. Japan took immediate action and initiated economic measures against Iraq even before the adoption of UN Security Council Resolution 661 which required its member countries to “1) prohibit imports from Iraq and Kuwait, 2) prohibit cooperation involving exports by the two countries, 3) prohibit exports to the two countries, and 4) prohibit service transactions with the two countries (MOFA, 1991)". Japan initially pledged to provide $\$ 400$ million to support the war efforts, but eventually raised the amount to $\$ 4$ billion.

However, even though Japan took swift action in economic terms, it refused to dispatch its SDF to support the war in terms of human contribution. The U.S. and other OECD countries all criticized Japan for a lack of "burden sharing". U.S. Congress members accused Japan of free riding on American defense and abstaining from fully supporting the war efforts (Cooney, 2007). When the Gulf War erupted, the U.S. faced both domestic fiscal and economic problems. In addition to trade frictions with Japan, the U.S. was heading into economic recession and government deficit (Midford, 2004). During such a period, Japan's insignificant contributions and nominal involvement, despite its dependence on the Persian Gulf for nearly $70 \%$ of its oil imports, outraged the U.S. (MOFA, 1991).

In response to Japan's deficiency in contributing to combating the Gulf War, the U.S. adopted swift measures to express its dissatisfaction. The House of Representatives voted 370 to 53 in favor of annually withdrawing five thousand U.S. troops from Japan unless Japan financed the costs of stationing the U.S. troops (Apple, 1990). In April 1990, the U.S. published its first East Asia Strategic Initiative (EASI), which stated that the U.S. would 
reduce its troops in East Asia by 14,000-15,000 personnel, including a 5,000-6,000 personnel reduction in Japan by the end of 1992. This initiative prompted Japan's concern that the U.S. was retreating from Asia (U.S. Department of Defense, 1990).

In response to U.S. dissatisfaction, Japan altered its policy and increased its financial contribution to $\$ 13$ billion and sent minesweeping units in the aftermath of the Gulf War. The international community was still not satisfied and criticized Japan's policy as "checkbook diplomacy". Even though Japan repeatedly emphasized that the financial contribution that Japan made was a significant step for Japan to participate in global affairs, when Kuwait placed a full-page report expressing its appreciation for countries that had aided Kuwait during the crisis, Japan was conveniently forgotten and left off the list (Abe, 2006).

Humiliated, Japan decided to change its foreign policy from one focused merely on economic diplomacy to one combining bilateralism and regional multilateralism. Japan's foreign policy gradually became assertive through multilateral institutions. As the second largest economy in the world, Japan started to pursue political power and influence commensurate with its economic might after the Cold War. With the changing strategic situation in the Asia Pacific, Japan was also forced to rethink its security policy that solely relied on the U.S. for protection. During this period, Japan started to embrace security multilateralism in addition to economic multilateralism. Therefore, Japan's promotion of regional multilateralism has not been limited to the economic realm as it was during the first phase, but has expanded to promote regional collaboration in security and political realms. 
In addition to changes in the international power structure and challenges in its relations with the U.S., China's rise has presented Japan with challenges in many dimensions: political, security, and economic. Following the Sino-U.S. rapprochement of 1972, Japan accelerated its engagement with China. Japan normalized diplomatic ties with China in the same year and concluded the Treaty of Peace and Friendship in 1978. While initiating direct economic and political relations, Japan and China deliberately shelved issues of the colonial past and territorial disputes over the Senkaku/Diaoyu Islands. Japan was able to bring its full economic power to bear on bilateral ties. Therefore, by the early 1980s, Japan was the largest donor of official development assistance to China. Between 1979 and 2005, it disbursed a total of 3.133 billion RMB in loans, 145.7 billion RMB in grant aid and 144.6 billion RMB in technical cooperation (Drifte, 2008). By the late 1980s, Japan had emerged as China's major investor and was a significant part of China's open door policy. Japan had begun to conceptualize China's place within a Japanese-led regional production order (Hughes, 2009).

However, tensions arose periodically in 1982 and 1986 due to Japan's presentation of its colonial past in history textbooks and in 1985 due to Prime Minister Nakasone Yasuhiro's visit to Yasukuni Shrine to pay homage to the spirits of Japan's war dead. Political tension overshadowed economic interests on both sides. Things changed when China rose and even surpassed Japan as the world's second largest economy as a result of China's economic reform. In the political dimension, Japan has had to contend with a rising and rapidly transforming China, which is perceived as less stable domestically, increasingly nationalistic, and thus more willing to confront Japan over issues of the 
colonial past. In the economic dimension, China has presented Japan a challenge to its “flying geese model". With China's remarkable economic growth in relation with Japan's economic stagnation, Japan has had concerns about Asia turning towards a new form of "Chinese world order", especially after the 1997 Asian Financial Crisis. In the regional integration dimension, China's rise has presented Japan with concerns that it is being edged out of its position as the dominant East Asian state and leader of regional integration efforts. Japan's previous 'special relationship' with ASEAN has been jeopardized by China's southward engagement with this sub-region and Japan has been for a short period disturbed by South Korea's flirtation with closer ties to China (Shambaugh, 2004). Therefore, Japan has had to move from behind the scenes to actively initiate and participate in regional agreements and institutions so that it can ensure its position in regional affairs and compete with China for dominant influence.

\subsubsection{Japan's policy towards regional institutions}

This section examines in detail Japan's institutional balancing strategies exercised in important regional institutions namely APEC, ARF, and APT. As revealed in the previous section, Japan's policy towards regional multilateralism has experienced ups and downs. Even though, Japan was the first among China, Japan and the U.S. to promote the ideal of regional multilateralism, it became reluctant to take the lead during several short periods

of time. However, since the 1990s, Japan has adopted proactive policies towards regional institutions to compete with a rising China and the U.S. This section unfolds Japan's APEC policy, ARF policy, and APT policy respectively to explore institutional balancing tactics that Japan has been using to balance China and the U.S. 


\section{Japan's APEC policy}

Even though APEC was developed under the joint proposal of Japan and Australia, Japan was the one that initiated the idea of formulating an Asia Pacific multilateral institution in order to promote economic cooperation, as reflected in the previous study of Miki's policy. Japan's initiation of APEC with Australia firstly aimed at balancing U.S. influence in the region in general and secondly at balancing U.S. pressure on Japan in trade disputes. Japan used the multilateral setting of APEC to divert U.S. intentions as well as constrain U.S. aggressive behavior toward Japan.

In the 1970s, as Japan maintained the world's most skewed import-export balance, the U.S. blamed Japan for taking advantage of the U.S.-Japan trade relationship. Since the 1970s, there was an increasing trade deficit between U.S. and Japan as Japan managed to export more manufactured goods to the U.S. than it imported from the U.S. In 1971, the U.S. started to suffer from a trade deficit of $\$ 2.2$ billion, which soon grew to $\$ 6.8$ billion in the next year. The U.S. trade deficit grew every year in the 1970s. Meanwhile, Japan's economic performance had been totally different. Since 1965, Japan had enjoyed a gradual increase in its trade surplus, which reached $\$ 5.17$ billion in 1972, almost as much as the U.S. deficit of $\$ 6.8$ billion (Chen). In addition, Japan successfully prevented foreign direct investment in Japan. Until the 1980s, only one percent of Japan's assets was owned by foreign capital.

The strong U.S. strong economy allowed the U.S. to tolerate Japan's surplus in the 1960s. However, Japan's trade deficit provoked resentment inside the U.S. in the 1970s and 1980s due to Japan's closed economy and free-riding policy. The U.S. started to 
complain that Japan was a free rider in the U.S.-led, liberal world order and did not return equal benefits to the U.S. In the early 1970s, U.S.-Japan trade friction focused on the export of textile products, which adversely affected the U.S. domestic textile industry. In the late 1970s, trade friction expanded to include automobile, beef, citrus, and steel exports to the U.S. In the 1980s, conflict over electronics and telecommunications worsened, which expanded to construction and satellites in the late 1980s.

There were two aspects of the U.S.-Japan trade friction. One aspect was that the U.S. accused Japan of penetrating the U.S. market with underpriced manufactured products. Another aspect was the difficulty that the U.S. faced when exporting its products into the Japanese market. Thus in 1988, the U.S. Congress passed the Omnibus Trade and Competitive Act which included the Super 301 provision, which asked the U.S. to adopt a tough posture and impose unilateral sanctions on unfair trade practices by foreign countries like Japan. Japan, in response, strongly opposed this provision and argued that it jeopardized the multilateral trade system and damaged the Uruguay Round trade negotiation (1989).

Frustrated by the U.S. unilateral retaliation and pressure, Japan then promoted the agenda of utilizing multilateral institutions to divert these trade disputes with the U.S. As Funabashi notes, Japan was interested in establishing a U.S.-Japan trade dispute settlement mechanism in the APEC multilateral setting from the start of the APEC process. Japan thought that it would then be difficult for the U.S. to impose the 301 provisions against Japan in a multilateral system. Australia's original plan was to exclude the U.S. from APEC. However, as stated in the 1988 MITI White Paper, Japan clearly stated that it would 
encourage the participation of the U.S. in the APEC. The reason why Japan did that instead of excluding U.S. in APEC was not for public goods, but was mainly driven by its realist agenda of self-interest.

There were two motivations behind Japan's proposal to include the U.S. in the institution during this time. One was to help U.S. to get access to the Asian market to absorb American exports and investments, so that the pressure on Japan would be diverted to other Asian markets. Another reason was to include the U.S. in the multilateral setting with other powers such as Australia so that it would be easier for Japan to prevent the U.S. from adopting a protectionist policy against its exports.

Japan's institutional balancing strategy was reflected in its initiation and promotion of APEC. As noted previously, when Miki first approached Australia hoping to establish a multilateral institution, his rationale was to balance the influence of the U.S. in the AsiaPacific and get Japan more bargaining power in its relation with the U.S. In the 1980s, when facing increasing pressure from Europe and North America, Japan played a leading role again in promoting APEC in order to counterbalance the pressure by stimulating free trade within the Asia Pacific and constraining the U.S. from adopting unilateral economic sanctions within the multilateral framework. After the establishment of APEC, Japan continued to follow an institutional balancing strategy by pursuing its economic interests through setting preference rules and agenda in the multilateral process.

\section{Japan's ARF policy}

Japan's participation in ARF can be regarded as a strong case showing that Japan has been using institutions as a platform to balance Japan's bilateral alliance with the U.S., 
which has been seen as the pillar of Japan's security policy. As reflected in the Yoshida Doctrine, U.S. protection is the sole defense that Japan has for its security. However, U.S. security protection is not free. U.S. has put pressure on Japan to act on behalf of U.S. interests in regional affairs, such as the Korean War and the Vietnam War. In addition, the U.S. has kept on putting pressure on Japan to increase its military capability and share responsibilities of protecting regional security instead of being a mere free rider. For example, during the Vietnam War, the U.S. pressed Japan to send its SDF personnel to Vietnam to help U.S. in the war. But Japan refused to do so, invoking the Yoshida Doctrine and Article 9.

In the 1980 s, the idea of establishing a multilateral security institution spread in the Asia Pacific. For instance, in 1986, the Soviet Union proposed the Pacific Ocean Conference as an extension of the Helsinki Conference to discuss regional security in a multilateral framework. In addition, in 1990, both Australia and Canada suggested a CSCEtype, multilateral security institution to address security issues in the Asia-Pacific region (Fukushima, 1999). The U.S. was not interested in such an idea and was against it as it challenged its bilateral arrangements in the Asia Pacific region. Japan, although initially favorable, rejected this multilateral security institution proposal.

There were several reasons behind Japan's rejection of a multilateral security institution before the 1990s. Tokyo's official reason was that security multilateralism was inappropriate in the Asia-Pacific region due to the diversity in economic, political, and social systems as well as the lack of common threat shared by the states in the region. Another reason was that the original initiative for such security multilateralism was 
proposed by the Soviet Union, which aimed at promoting arms control in the Asia Pacific. Since Japan was largely dependent on U.S. naval presence in the region, Tokyo perceived the proposal as counterproductive to regional security (Satoh, 1991). Australia's and Canada's proposal was not in Japan's interests either. The establishment of CSCA was derived from CSCE, which could lead to consolidation of postwar national boundaries. Japan was then worried that such development would generate a false interpretation that Japan accepted the territorial status quo over the Northern territories (Soeya, 1994; Midford, 2000).

In July 1991, in Kuala Lumpur, at the annual ASEAN Post Ministerial Conference, marking a changing stance on security multilateralism, Japan's Foreign Minister Nakayama Taro proposed a multilateral security dialogue in the region. Nakayama advocated the creation of a multilateral security dialogue within the ASEAN PostMinisterial Conference (PMC), the creation of a supporting Senior Officials Meeting (SOM), and proposed that clearing up Asian's fears about Japanese remilitarization should be a primary focus of this dialogue in line with promoting regional cooperation to ensure regional peace.

What is necessary for the Asia-Pacific region is to exploit the various types of existing mechanisms for international cooperation and dialogue in a comprehensive and multi-tiered manner... Should any mechanism be added to these cooperative venues in economic [ASEAN, ASEAN PMC, APEC and PECC (Pacific Economic Cooperation Council)], diplomatic [efforts in Cambodia and the Korean Peninsula] and security [Japan-U.S. security treaty and other bilateral alliances] realms, it would be a political dialogue where friendly nations in the region candidly exchange their mutual concerns...The dialogue that friendly nations have for the sake of mutual reassurance is intended to solidify further the political basis for cooperation between and among one another...I believe utilizing ASEAN PMC as such a political dialogue forum for mutual reassurance is timely and meaningful. In order to 
make such a political dialogue more effective, I think it is also meaningful, for instance, to establish, under the auspices of this conference, a Senior Officials Meeting to provide the conference with feedback on the result of discussion at the meeting (MOFA, 1991).

The Nakayama's proposal represented a bold departure from Japan's reactive policy towards regional security issues and marked the first initiative on its own in terms of security affairs.

As discussed previously, due to the changing balance of power after the Cold War, Japan adjusted its regional strategy. Meantime, by the mid-1990s it had become clear that some of ASEAN's most influential defense intellectuals had started to think about the possibility for ASEAN to establish "new inter-governmental measures for region wide conflict-resolution and cooperation" (ASEAN-ISIS, 1991). On Japan's side, this provided a great chance for it to enhance its relations with ASEAN countries, which had a long and special importance for Japan's postwar diplomacy. Unlike northeast Asian countries, Southeast Asian countries had experienced a shorter and less brutal invasion from Japan's imperialism and thus had been less suspicious of Japan's intentions after the war. Therefore, Japan has promoted a special relationship with the non-Communist ASEAN states since the Fukuda doctrine. Because of the relatively closer diplomatic relationship that had developed between Japan and the ASEAN since the late 1970s, ASEAN was the best potential partner for cosponsoring a new security regime for Japan (Takeda, 1992).

In addition, the expectation of a declining U.S. military presence and commitment along with an already declining Soviet military power increased Japan's actual and potential regional military might. However, due to the suspicions of other Asian countries, multilateral institutions provided an ideal setting for Japan to increase its influence while 
persuading other Asian nations that Japan's rise and participation could be constrained within a multilateral setting and would be beneficial for other Asian countries.

Japan's ARF policy lies at the heart of Japan's regional security multilateralism. Foreign Minister Yohei Kono revealed Japan's basic posture when he stated that, though Japan's security alliance with the U.S. would continue to be the foundation of Japan's security policy, in the long run ARF would serve to contribute to easing tensions or eradicating the root causes of conflict through the increase in transparency and the enhancement of mutual trust, which would eventually bring regional peace (MOFA, 1995). Japan's interests in ARF especially lie in ARF 's mutual reassurance measures (MRMs). MRMs consist of three pillars: 1) 'information sharing' to increase transparency of policies of individual countries. Information refers to information about defense policy and arms procurement. Member countries of ARF can achieve information sharing through the publication of defense white papers or presentation of defense papers at ARF as well as the ARF-SOM. 2) 'Human exchange' to deepen mutual understanding and trust. Human exchange refers to exchanges of security-related personnel such as military exchange and reciprocal visits. 3) 'Cooperation toward the promotion of global activities'. This includes activities such as convening seminars on peacekeeping operations, which aim to share experiences of activities at the global level such as the United Nations and to perform such activities more effectively (MOFA, 1995).

Another mechanism that attracted Japan was ASEAN's Treaty of Amity and Cooperation (TAC), a non-aggression treaty and an underlying foundation of the ARF. China signed a declaration of conduct in the South China Sea with ASEAN in 2002 and 
the TAC in 2003. China's softened gesture and its charm diplomacy was perceived by Japan as one of the achievements of ARF. Japan thought that within the multilateral setting, even if it would not be able to transform China's policy, it would be able to constrain it, to some extent. Therefore, having a territorial dispute with China over the Senkaku/Diaoyu Islands, Japan hoped to constrain China's assertive policy and negotiate with China within ARF's multilateral framework. As evidence of this intention, Japan has repeatedly raised the issue of Senkaku/Diaoyu issue at the ARF meeting (Simon, 1999).

It is worth noting that Japan's institutional balancing in ARF has not been a smooth process but has experienced failures and frustrations. For instance, after the 1996 Taiwan crisis, Japan attempted to raise the Taiwan issue in ARF, but both China and ASEAN countries strongly opposed Japan's initiative since the Taiwan issue was seen as a domestic issue of China under China's purview. Despite frustrations and disappointments, Japan still actively participates in ARF, as even though Japan did not accomplish its leadership role through the ARF, it still recognizes the instrumental role of ARF in binding U.S. interests, constraining China's behavior, and advancing its status in regional security.

\section{Japan's APT policy}

For Japan, APEC is an economic institution and ARF focuses on security. Japan's policy towards APT is mainly rooted in its political resentments towards the U.S. and its competition with China for regional leadership after the 1997 Asian Financial crisis. Through this institutional setting, Japan conducted dual track institutional balancing: exclusive balancing towards the U.S. and inclusive balancing towards China. The 1997 Asian Financial crisis hit Japan by affecting its banking and financial system, however, the 
U.S. as Japan's ally did not contribute significantly to assist suffering Japan as Japan expected. In response to the Asian Financial crisis, Japan proposed the Asian Monetary Fund (AMF) as its solution to the crisis, which is a yen-based financial institution as a counterpart of the IMF. The main purpose of the AMF was to construct an Asian fund to stabilize Asian currencies. However, the U.S. and the IMF did not accept the proposal and even attacked the Japan's proposal as a threat to the authority and effectiveness of the IMF and the dominance of the U.S. dollar. The heavy-handed U.S. intervention in the AMF plan awakened Japan to the importance of exclusive Asian regionalism.

Since that crisis, Japan has no longer insisted on promoting open multilateralism in the region. When Miki first proposed the establishment of multilateralism in the Asia Pacific, he proposed one that was open to all actors, especially to the U.S. Subsequently, Japan opposed any exclusive institutional building in Asia targeted on the U.S. For instance, in the early 1990s, Japan did not support the EAEG and EAEC proposals by Malaysia as these proposals promoted an exclusive regional trading and economic bloc in East Asia excluding the U.S. Japan had always emphasized the U.S. as an important player in regional affairs through APEC and ARF as it did not want to alienate its security partner. However, its stance in the APT diverged from its previous posture. Through the APT, Japan adopted exclusive balancing towards the U.S. The exclusion of the U.S. from APT helps Japan unite Asian countries to resist the influence of the U.S.

Another target of Japan's institutional balancing in APT is China. The economic crisis taught ASEAN countries the vulnerability of their economies and encouraged them to seek regional solutions instead of counting on the IMF and World Bank. Therefore, Malaysia's 
EAEG and EAEC proposals revived in Asia. The 1997 Asian Financial crisis gave China a great opportunity to emerge as a regional leader, which threatened the potential leadership of Japan. Therefore, even though Japan was at first reluctant to participate in the exclusive APT out of fear of U.S. opposition, it still became a member as it did not want to be left out of this regional institution and let China dominate it. Initially, Japan was interested in establishing a bilateral relation with ASEAN. In January 1997, Japan launched the "Hashimoto Doctrine", which proposed an annual summit between Japan and ASEAN leaders. However, ASEAN was not interested in this bilateral arrangement as it might have alienated China from ASEAN as, for ASEAN, both Japan and China were important for its economic recovery (Tow, 2001). Therefore, Japan had no choice but to adopt inclusive institutional balancing against China within the APT.

In the institutional politics of APT, Japan's financial contribution was seen as indispensable for successful regional cooperation thus Japan intended to play a leadership role in the institution. However, Japan's leadership was challenged by China. ASEAN benefited from Japan's balancing role against China's domination, but it also intended to use China to check Japan's ambition. Therefore, the political rivalry between Japan and China within APT has made ASEAN the default leader, which has prevented APT from developing further. The mutual balancing situation between China and Japan has hampered the progress of APT in the way that it has been hard to reach agreements within the APT.

In 2001, China and ASEAN reached a bilateral agreement to initiate an FTA in 2010. The following year, to balance China's increasing sway, Japan signed bilateral FTAs with several ASEAN countries including Singapore, Indonesia, Malaysia, and Thailand. In 
addition, in 2002, Japan and ASEAN signed the Comprehensive Economic Partnership Agreement aimed at building a potential FTA in ten years. As Mohan Malik points out, the proliferation of FTAs is rooted in the rivalry between China and Japan, as neither Japan nor China wanted to be left behind in promoting regional integration (Malik, 2007).

In 2005, at the first meeting of the East Asia Summit (EAS), institutional balancing between Japan and China intensified as they had different visions for the development of EAS. Japan promoted a broad vision for EAS with an East Asian Community including Australia, New Zealand, and India. China, however, promoted a narrow vision for EAS and suggested that the EAS should stay within the APT framework. Eventually, Japan's proposal won the competition with China. EAS finally included Australia, New Zealand, and India. However, the precondition for this arrangement was to preclude the U.S. from participating in the EAS. Japan's proposal to promote a 16-nation free trade bloc based on the EAS membership was also vetoed by China as China insisted that APT should be the major framework to promote economic cooperation in East Asia.

As revealed in this section, due to the historical burden of WWII, Japan's foreign policy has been heavily distorted with a striking discrepancy between Japan's growing economic power on the one side and constrained political and military power on the other. Multilateral regional institutions provide Japan platforms to engage in what normal states always do, for instance balancing and counterbalancing through agreements and negotiations. In the Asia Pacific, the U.S. and China are two major competitors of Japan. Japan has adopted an exclusive institutional balancing strategy and inclusive institutional 
balancing strategy respectively against the U.S. and China in order to protect its economic and political interests. 


\section{CHAPTER V APEC CASE STUDY}

Despite its debatable progress after twenty-eight years, APEC remains the strongest regional institution in promoting economic and political cooperation in the Asia Pacific. It encompasses all the major powers with a stake in the region's economic prosperity and security. Through years of development, APEC has helped to create a minimalist normative bargain in the Asia-Pacific region. It has helped to institutionalize power relations legitimizing the role of the great powers as well as the voice of smaller states in regional economic and political relations.

This section turns to a specific examination of the interests of China, the U.S. and Japan in APEC and the challenges for these three countries to realize their initiatives in APEC and it reveals how these countries have exercised institutional balancing to achieve their goals. To analyze the policies of China, the U.S. and Japan in a clear way, the APEC process can be broken down into three phases: 1) 1989-1993: establishment of APEC and early formative years; 2) 1993-1997: early development of APEC gaining importance in a relatively favorable economic and political environment; 3) since 1997: struggle to achieve further development.

\subsection{Introduction}

The establishment of APEC was a rational response to the changing dynamics in the 1980s. At the close of the 1980s, international relations in the Asia Pacific featured the loss of previous uncertainties and the growth of a strong sense of opportunities and confidence in East Asia community. With the economic growth and the rise of interdependence, there 
had come a substantially positive effect on domestic and regional political stability, but also a diffusion of power, a proliferation of new political actors, and a growing gap between economic, social, and technological dynamics, and the much slower adjustment of political institutions (Maull 1993). Under this situation, economic and cooperation of a breadth and reach, which could not be mustered bilaterally, was required to exploit economically and politically the new opportunities and to safeguard against the new uncertainties. The idea of APEC served this purpose. It not only promised a constructive way to manage trade disputes between the East Asian community and the Western community but also provided a way of integrating the economic powers in the Asia-Pacific, especially China, the U.S., and Japan.

Over twenty-eight years of development, the scope of APEC's cooperation has widened to include even security issues such as anti-terrorist cooperation and the institution has expanded to include many committees, sub-committees, and working groups. Governments consider APEC a useful tool to push for preferential agenda and to practice an institutional balancing strategy. From an economic perspective, one reason for countries to participate is to facilitate intra-APEC transnational economic relations and cooperation. APEC, with its committees, sub-committees, and growing number of working groups is well placed to exploit opportunities to facilitate interaction and reduce transaction costs. APEC contributes to the international socialization of bureaucracies and helps to develop public policy networks, which bring together relevant representatives of governments and the private sector. These networks can be used to promote effective sectorial international cooperation (Reinicke 1997). 
From a political perspective, one of the most banal examples of APEC's usefulness lies in its annual Leaders' Meeting, which provides not only opportunities for multilateral discussion and negotiation, but also opportunities for bilateral get-togethers on the margins. For instance, the APEC Leaders' Meetings in Manila and Wellington in 1996 and 1999 respectively provided the backdrop for bilateral summits between Chinese president Jiang Zemin and U.S. president Clinton, which helped to put relations between the two powers back on track after severe tensions over the Taiwan Strait confrontation in March 1996 and the U.S. bombing of the Chinese embassy in Belgrade in May 1999. The meetings are a very effective means for members to conduct summit diplomacy, using a summit meeting as an opportunity to diplomatically interact with multiple states and promote national interests.

APEC, as one of the most influential regional institutions in the Asia Pacific region, holds strategic importance in the grand strategy of China, the U.S., and Japan. For example, APEC offered China the first regional platform after the Tiananmen Square Incident to break containment by the West and to convert its growing economic power into political influence in the region. For the U.S., to which the economic importance of the Asia Pacific had become evident in the 1980s, APEC was a means for the U.S. to ensure its access to the markets of Asian states by shaping institutional agenda and norms and thus retain influence in the region at a time when Japan and China were growing as regional great powers. For Japan, the states in APEC currently are Japan's most important trade partners as shown by Japan's exports and imports structure. The top three export destinations of Japan are the United States $(\$ 128 \mathrm{~B})$, China $(\$ 116 \mathrm{~B})$, South Korea $(\$ 44.6 \mathrm{~B})$. The top three 
import origins are China (\$152B), the United States $(\$ 63.5 \mathrm{~B})$, Australia $(\$ 30.7 \mathrm{~B})^{9}$. As the most advanced economy in Asia, Japan has wanted to claim leadership in the region. However, Japan has faced the constraints of its Constitution and its bilateral alliance with the U.S. Thus Japan's goal of being a regional leader has been more likely to be successful in the economic arena through regional institutions.

One feature that makes APEC an important institution to examine is the tri-polar rivalry within the institution. As Werner Pascha notes, one feature that makes APEC an interesting regional institution to examine is that three of its most influential membersChina, the U.S., and Japan- are all countries with little culture of international integration with equal power distribution, meaning that none of these three is acculturated to interacting with other nations on an equal footing (2007). This point especially applies to analyzing the cases of China and Japan. China was the "Middle Kingdom" and the head of the Tributary system that at its peak time included Korea and Japan. Japan after the Meiji restoration, expanded its imperialism in Asia and tried to rule East Asia as the sole power. The U.S. is a mixed case, a leading promoter of multilateralism and a global hegemon taking a unilateral stance on many global issues. None of these three powers has a history of sharing regional dominance with other actors.

Within APEC, there is no obvious power gap among China, the U.S., and Japan, which provides any of the three an opportunity to increase its relative sway in this institution. Oran R. Young has discussed critical determinants of "leadership" qualities in institutional arrangements such as APEC. He distinguishes three kinds of leadership: 1) structural

\footnotetext{
${ }^{9}$ Data available at http://atlas.media.mit.edu/en/profile/country/jpn/.
} 
leadership, which is based on the bargaining leverage made possible through having material resources at one's disposal; 2) entrepreneurial leadership, which is based on superior bargaining skills, for instance in terms of forming alliances; and 3) intellectual leadership, for instance, the ability to shape the perspectives of others and thus move them in a desired direction (Young 1991:287-288). All three countries qualify for these types of leadership and power in different ways. So, then the question is: Can all three countries lead in one regional institution?

Liberal institutional scholars suggest that these three powers can share leadership in a constructive manner for the sake of shared interests in deepening economic integration; realist scholars often scoff at this suggestion and note that there is unavoidable competition between these three powers. Richard Higgot notes in his observation of APEC that there is little likelihood during the stage of the Seattle Summit that APEC has sufficient institutional strength to provide a framework within which the U.S. and Japan can share policy leadership. Reliance on the beneficial role of the market in institution building in the region is not adequate to break the natural power balance. Market-led theories of integration and cooperation are underwritten by too robust a notion of rationality and have little of politics to sustain them (1995).

Within APEC, the three powers have each found it difficult to exert leadership and have not yet shown any intention of sharing leadership in a neutral way. In China, strategic thinkers have taken theories of power dynamics very seriously and remain skeptical of any initiatives that claim to be power-balance-neutral in regional affairs ( $\mathrm{Lu}, 1996)$. As mentioned above, East Asia has no tradition of multilateral power arrangements. The 
historical power structure of the region has been one of domination by the strongest regional power, first by China and then by Japan. Even though cooperation has occurred, Asian-style hegemony has been embedded in regionalism and ethnic solidarity rather than open power relationships. Therefore, within APEC, even though all three powers intend to cooperate, they also intend to balance each other, as they fear one of the others would dominate the institution. Not only this structural limitation but also divergence of interests prohibit China, the U.S., and Japan from sharing leadership in APEC.

APEC is now clearly at a crossroads. Even though it has tried to promote consensus and agreement among a disparate group of member economies, its development speed has significantly slowed down in comparison with that of the early 1990s. Its mission to promote trade liberalization originally by the year 2010 has passed and even the new deadline of year 2020 may not be met. The mechanism of early voluntary sectorial liberalization (EVSL), which advocates the negotiation and endorsement of sectorial arrangements in the APEC forum, had early success with the Information Technology Agreement. However, the sectorial approach to trade liberalization and efforts to extend this idea to many other sectors met severe resistance at the 1998 meeting (Aggarwal, 2000). Consequently, APEC, in recent years, has received widespread criticism for its stagnated development.

Donald K. Emmerson described APEC as "all talk, no walk" (2002). Institutional set up and mechanism have been analyzed as key problems impeding APEC's further development. For instance, the lack of enforcement of voluntary agreements in APEC has turned out to be problematic in pushing trade liberalization agenda. However, by reviewing 
the history of APEC's institutional development and meetings, this section notes that lack of practical progress and hesitation exhibited in APEC are not due to institutional deficiency as institutional analysts have emphasized, but also reflect fundamental political tensions within the APEC regime, mainly among the U.S., China and Japan, which impede APEC from progressing to change its institutional structure and expand its scope of cooperation not only on paper but also in practice.

The following section thus critically reviews this triangular power rivalry between China, the U.S. and Japan in APEC and unfolds the competition for benefits and influence that, under the surface of multilateral cooperation, has dominated the current institutional operation.

\subsection{Divergent Interests in APEC}

Yoichi Runabashi once described APEC as providing the Asia Pacific a new type of fusion, "Just as high temperature and pressure can join atomic nuclei to fuel the starts, the common interests of the peoples of the Asia Pacific can eventually meld Asian and Pacific civilizations to lend energy to the $21^{\text {st }}$ century $(1995,15)$ ". Runabashi noted that even though APEC member states had a diversity of culture, different levels of civilization, and a history of being hostile to each other, gradually these countries would fuse gradually and push regional development together. However, in the twenty-eight years since APEC's establishment, the fusion of interests and civilization that Runabashi envisioned has not yet been achieved and the development of APEC has stagnated. When APEC was just formed, institutional analysts largely shared Runabashi's perception of APEC's future development 
addressing common interests of its member states. However, analysis of the divergent interests of its key members, China, the U.S., and Japan has been inadequate.

With economic security being one of China's priorities, the APEC forum has become a matter of high policy interest in Beijing and networking in APEC has become a central method of exercising institutional balancing. In comparison with international multilateral organizations, such as the World Trade Organization, regional institutions provide China a better opportunity to exercise its power and influence. One important reason for that is in international multilateral organizations, China, previously an isolated country, was a latecomer. When China joined these organizations, norms and rules were already set up and China had no choice but to abide by the existing framework. In regional institutions, China either as a founding member or early participant has had more room to exercise institutional balancing as it can get involved in the process of establishing the institutions.

For China, APEC is an important institution, because there was no other similar region-wide mechanism and because it contributes to what Qian Qichen, the Chinese foreign minister, calls "a virtuous cycle of mutual promotion" between economic prosperity and a stable regional security environment (Harris, 1995). APEC also was the first significant step that Beijing made as a reflection of its changing policy towards regionalism. Problems over the nomenclature of Taiwan delayed China's membership in many regional settings. However, China started to realize that only through inclusive institutional balancing could China on the one hand avoid being left out and on the other hand lobby within institutions for support of its stand on Taiwan. 
U.S. interests are not as well defined as those of China. The nature of the U.S. foreign policymaking process is a critical factor in understanding U.S. policy towards APEC. Generally speaking, in the American political and governmental systems, power is diffused, leading to multiple outlets of access and influence. Thus, U.S. policy on complex issues is frequently the sum of a mixture of interests and perspectives, some of which may even be mutually inconsistent (Baker 1998, 165). During the Cold War period, because of a clear problem hierarchy that placed security and political objectives over commercial interests, the tendencies of multiple priorities and points of interest group access were more strictly controlled than in the present era. Lacking a prevailing security priority, interest groups find more opportunity to lobby for their interests. Therefore, the U.S. approached APEC with mixed motives, not single-minded coherence (Aggarwal, 2002).

In the 1970s and 1980s, many smaller states in the Asia Pacific area wished to draw their largest partners into a bigger organization that would prevent isolation if the trend turned toward discriminatory trading blocs and lessen U.S. unilateral pressure for market openness. ASEAN countries had observed U.S. trade strategy as heavy-handed in U.S. reliance on the use or threat of use of the Super 301 Clause of the Omnibus Trade Competitive Act (Plummer, 1998, 307). The motive of binding the hegemon also has been the central driving force behind the promotion of APEC.

The U.S., on the hand other hand, was not interested in Asia Pacific economic cooperation and was not interested in regional multilateralism in Asia. Not only was the U.S. not involved in the initial development of any intergovernmental institution in the Asia Pacific, but also the initial reaction of the newly inaugurated Bush administration 
towards Australian Prime Minister Bob Hawke's speech proposing a ministerial meeting on the establishment of an Asia Pacific regional institution was restrained. Confident in its traditional unilateral and bilateral approach and skeptical of the prospects for a multilateral approach, the Bush administration remained opposed to a multilateral approach to dealing with economic and political security issues in the region. In 1992, when an APEC summit meeting was proposed again, the U.S. was cautious and no action was taken. In Bush's election campaign, he had stated that he would pursue bilateral free trade agreements with some Asian nations (Baker 1998).

It was not until the 1993 Seattle meeting that the U.S. began to take APEC's potential seriously but it still did not respond with an active and cohesive strategy towards APEC. Despite constant efforts to promote multilateral regional institution following the 1993 Seattle summit, the Clinton administration's actual actions toward Asian trade partners were featured by a heavy reliance on bilateral negotiations and unilateral action (Aggarwal and Lin, 2002). Critically reviewing U.S. involvement in APEC at the initial stage, U.S. policies were basically reactive rather than proactive. The decision to join APEC was made largely based on the rationale of not wanting the U.S. to be left out and letting Australia and Japan have a chance to take the lead in the regional affairs. In other words, joining APEC was a result of U.S. interest in balancing the power structure in the Asia Pacific region.

From the U.S. business community, APEC also received a mixed reception. While American exporters were contented with their government's promotion of reducing barriers to market access, mainstream American businesses were interested in preserving 
barriers to Asian imports that threatened domestic industries (Baker 1998). With the changing awareness of the importance the Asia Pacific region, the U.S., pressed by a variety of lobbies, pushed APEC to include a number of issues other than voluntary trade and investment liberalization. As a result, APEC's issue scope now includes trade and investment liberalization, infrastructure, the environment, social issues, financial coordination, and women's issues.

In the post-Cold War environment, Japan had to find an encompassing cooperative framework on its doorstep, which allowed it to conduct its economic relations in a peaceful, trouble-free environment. In general, Japan's interests in APEC are multifold. First, Japan wanted to contain U.S. unilateralism and prevent the Western Hemisphere from becoming protectionist towards Japan's competitive exports. The absence of a multilateral framework in the region tends to provoke U.S. unilateral action and intensifies U.S.-Japan economic friction. Second, Japan wanted to engage China in the region so that its aggressive potential to pursue regional supremacy could be contained. As one of the largest investors in China, it is in Japan's interest to engage China in a regional institution framework so that it adheres to multilateral agreements and international law. Even though in general China-Japan bilateral trade has grown steadily in past decades, turbulent moments have occurred whenever nationalist fever has spread in China. Japan has good reasons to fear nationalism that would be unleashed if China's economic growth stagnated. Another concern is China's advances into the South China Sea. APEC for Japan was a starting point to engage China within a regional institutional framework to prevent it from breaking trade agreements or adopting protectionist policies towards Japan. Third, Japan wanted to strengthen ties with 
ASEAN countries and to promote globalism in and from the region to elevate itself from a regional political power to a global one. Fourth, Japan facilitated access for its companies in the Asia Pacific region through a wide range of co-operative task forces and projects.

It is worth noting that as in the U.S. different domestic actors influence Japan's interests in APEC. The Ministry of International Trade and Industry (MITI) and the Ministry of Foreign Affairs (MOFA) had serious dissenting opinions about APEC at its inception. MOFA argued for a more comprehensive dialogue, including security and political cooperation, on top of trade and investment, among regional countries. However, MITI was interested in focusing on trade and investment, as the region that APEC covers is crucial for Japan's trade development. The MITI/MOFA divide was evident especially in the first stage of APEC's development. The ministries were so divided that representatives of each routinely held separate meetings with the SOM chairperson until the 1991 conference. Both MITI and MOFA ministers clamored for a seat at the head table at official gatherings, where the chief delegation from each country was to be seated. Until APEC upgraded to the leaders' level in 1993, MITI played a more important role in determining Japan's policy towards APEC, while MOFA had scant involvement, which made MOFA fight with MITI over APEC policies and reluctant to facilitate MITI's APEC objectives.

MOFA is automatically involved at summit-level conferences and expected the leaders' meetings could guarantee it a larger role in formulating APEC policy. However, MOFA's debut as a major player in APEC during the Seattle meeting in 1993 was marred by the poor performance of its Asian Affairs Bureau and MOFA lost its APEC responsibility to 
the Bureau of Economic Affairs for a short period. This shed light on the inconsistency of Japan's APEC policy-making. In addition to the MITI and MOFA division, other ministries involved with different interests all have their own perception for APEC and wanted to direct agreements into their preferred direction. For instance, there was a fierce turf battle between MITI and the Ministry of Posts and Telecommunications (MPT). Both representatives presented at the discussion table, while one person represented all other delegations. They could not reply to one another as they independently supported different Japanese projects in this area. Because of such incompatible interests among ministries, Japan's APEC strategies, policies, and actions sometimes are contradictory.

\subsection{Balancing through APEC}

The institutional balancing of China, the U.S., and Japan within APEC has been dynamic and intense. By reviewing and analyzing China, U.S. and Japan's interaction in APEC, this section discovers three methods of exercising institutional balancing from these three powers' practice. All three states have tried to balance each other's influence in APEC's multilateral framework through ensuring membership, shaping APEC norms, rules, and mechanism, and pursuing balancing alliances.

\subsubsection{Ensuring Membership}

APEC is a hard case in examining how China, the U.S., and Japan use membership as a way of exercising institutional balancing as all these states are part of the institution and cannot use exclusive membership strategy towards each other. While exclusive institutional balancing is not an option, China, the U.S. and Japan have used inclusive institutional balancing. As some APEC scholars have pointed out that the idea of APEC 
could still be sunk if it encountered resistance or opposition from either one of the two great powers in the region at that time: China and the U.S. (Aggarwal, 2000). This scenario was quite possible, as both states were not interested in regional multilateralism in the form of a regional institution when the idea of APEC was first put on the table for discussion. Both acquiesced, however, and even came around to supporting APEC. Both Washington and Beijing observed that the trend of growing regional multilateralism was unpreventable and were afraid of being left out. Therefore, instead of opposing to the establishment of APEC, the U.S. and China joined the APEC successively.

The first important institutional balancing strategy that China exercised through APEC was conducted through its admission into APEC and negotiation regarding membership of Taiwan and Hong Kong. Beijing's policy had the preconditions that there was only one China and the People's Republic of China would join APEC as a sovereign country, while Taiwan and Hong Kong would join as regional economies. In dealing with APEC members, whether bilaterally or multilaterally, China has constantly and consistently demanded adherence to this position that Taiwan is part of China and could not be treated as a sovereign state. Beijing also insisted that only Taiwan's economic minister could attend the meeting while its foreign minister could not. China prevented Taiwan's leader, Lee Tenghui, from attending the Seattle summit, in part because several Asian APEC members warned Washington that to invite Lee was to risk China's wrath $(1993)^{10}$. Eventually. Taiwan agreed to join APEC under the name of Chinese Taipei and only send its economic minister to meetings.

\footnotetext{
${ }^{10}$ Remarks attributed to Malaysia's Mahathir and Indonesia's Suharto, Business Times (Singapore), 19 July 1993.
} 
The sensitivity of the Taiwan issue remained even after China, Taiwan, and Hong Kong joined APEC in 1991. Under pressure from China, Indonesia's president Suharto rejected Taiwan's request to allow Lee to attend the Bogor summit. The Japanese foreign minister, Yohei Kono, noted that Japan understood China's position and would conduct its Osaka meeting on the basis of the model established at Seattle and Bogor, in which Lee would not be invited (Reuters, 1994). In addition to constraining the form of Taiwan's representation in APEC, China insisted that APEC's agenda should focus on economic issues rather than political and security problems. One of the reasons for China's position stemmed from the worry that expanding the APEC agenda would involve discussions on the Taiwan issue, which was treated as an internal affair of China and not meant for a multilateral setting. When U.S. Defense Secretary Perry suggested discussing security issues of the Asia Pacific region at the Manila meeting, China rejected this proposal and suggested that it should not be listed on the agenda of the 1996 Manila APEC summit (Congressional hearing, 1996).

In the initial phase of APEC's development, Japan chose to use inclusive institutional balancing against the U.S. Instead of excluding the U.S. from APEC, Japan chose to compete with and constrain the U.S. by forming a balancing coalition within the institution. Japan needed to include U.S. in APEC to realize its purpose of ensuring access to U.S. market. Facing mounting criticisms of its closed market from the U.S., Japan found it hard to fight the free trade pressure alone. Therefore, including U.S. in APEC provided Japan a better chance to make alliance with developing countries in the Asia Pacific region that were also reluctant to fully liberalize their market. 


\subsubsection{Shaping APEC's Norm, Rules and Mechanism}

Shaping institutional norms, rules, and mechanism is the most commonly practiced institutional balancing tactic. The institutional balancing of China, the U.S., and Japan within APEC through the process of determining APEC's norms, principles, and institutional structures has been intense. There have been disagreements over APEC's mechanisms, structure, norms, and principles. China, U.S., and Japan have all tried to shape APEC in their preferred way and balance the influence of the others. As founders of APEC, the U.S. and Japan started to practice this tactic in APEC before China. While Japan has tried to keep a low profile in establishing APEC under MOFA's pressure, the U.S. has been more aggressive in shaping APEC's norms and rules in the early stage.

From the beginning of APEC in 1989, the U.S. has looked upon this institution as a vehicle for helping develop the kind of economic institution and regulatory environment in the Asia Pacific region compatible with American norms and principles. The growth of regionalism in the Asia Pacific occurred when the development of the international multilateral framework, dominated by the U.S., started to stagnate. Participating in a regional organization, even though not the initial U.S. plan, offered U.S. an emerging platform to promote its norms and principles and accelerate a consensus establishing process in international organizations by reaching agreement firstly at regional level.

In 1993, the U.S. elevated the APEC meeting from the ministerial level to the leader's summit, which signified the U.S.' first institutional balancing act through APEC. There were two reasons behind this action: First, the U.S. tried to ensure its leadership in building this multilateral economic institution in Asia Pacific after being absent from the initial stage; 
second, after recognizing the importance and unavoidable tendency of the growth of regional institutions, the U.S. wanted to take the advantage of being an experienced great power in establishing multilateral institutions and copy its experience in developing APEC. As Secretary Warren M. Christopher remarked, "After WWII, the U.S. led the effort to create multilateral institutions that sparked European recovery and helped sustain prosperity... In this new era, we wanted to bring the same approach to engaging our Asian partners. Strengthening APEC fit squarely into that vision (1998)."

Furthermore, the U.S. successfully pushed for a detailed economic and trade liberalization framework within APEC through the Bogor Goals and Osaka Action Plan, which both China and Japan were reluctant, to different degrees, to push to be the main goal for APEC. As mentioned before, since the late 1970s, the U.S. encountered severe trade deficits with its Asian allies, especially with Japan, due to high tariffs and other, nontariff, barriers to U.S. exports. The U. S. government faced great pressure from a trade deficit accompanied by a domestic economic recession, which made it imperative for the U.S. to solve this trade imbalance with Asian countries. APEC provided the U.S. a multilateral arrangement, which has many institutional functions facilitating economic liberalization. For instance, it could lower U.S. transaction costs to make agreements. Besides economic reasons, trade and investment liberalization was promoted as a norm in line with U.S. world-wide promotion of its soft power through norm building. Through promoting trade and investment as a goal of APEC, the U.S. tried to sell its development model to APEC countries as an addition to Japan's government involved export-led growth model. 
Taking the agriculture sector as an example, the Clinton administration aimed to pressure protected agricultural markets to eradicate export subsidies, cut tariffs, and lessen barriers against biotechnology, which is one of the U.S. agrochemical sector's strong suits. At the 3rd APEC Ministers' Conference on Regional Science and Technology Cooperation, held in Mexico City, October 21-23, 1998, food security, after years of unofficial discussion, was brought out for the first time. Since then, food security became one of the key topics for negotiation among China, the U.S., and Japan. Food security is a comprehensive concept that can be used to promote agricultural liberalization as well as used as an argument for agriculture protection and for some degree of self-sufficiency. This has especially been the case in East Asia, because in recent years, there has been little improvement in rice yields in Asia. It was feared that there was no chance for significant improvement over the yields achieved by the high-yield varieties that heralded what was called the Green Revolution.

For the U.S., as Senator Baucus once noted at a congressional meeting, "no trade discussion is complete without a focus on agriculture $(2011,23)$ ). For the U.S. economy agriculture is an important sector not only for the interests of the U.S. government but also for relevant interest groups. APEC is a region in which half the world's population resides. Therefore, ensuring access to APEC's agricultural market is an important task for the U.S. representatives at APEC.

However, Japan has been reluctant to liberalize its agriculture sector. Even though Japan agreed to the GATT provisions for rice liberalization, it did so with a minimal pledge to import four percent of domestic consumption in 1995. As for APEC, the Ministry of 
Agriculture, Forestry, and Fisheries (MAFF) repeatedly cautioned MOFA that agriculture products should be awarded the special status of "non-trade-able goods", to prevent the provisions for rice from being liberalized.

While the U.S. took the lead in shaping APEC in terms of institutional development, norm building, and agenda setting, Japan also strived to contribute to APEC institutional establishment and norm building. China as a latecomer, with its strong economic power, also emerged with its own proposal of what APEC should be in opposition to the proposals of the U.S. and Japan.

For historical and strategic reasons, Japan has been promoting the idea of "open regionalism" through the course of APEC's institutional development. To be an open regional institution, Japan has promoted APEC to be not exclusive to Asian members, as a Malaysian president initially suggested, but open to countries from all over world that are interested in free trade and economic cooperation. APEC should not be an economic bloc or legally bound free trade area like the North American Free Trade Agreement or the European Community. In addition to open membership, Japan agreed that APEC should use "soft negotiations" to achieve flexible consensus.

China has tried to shape APEC as a flexible and voluntary regional multilateral institution. Its APEC rhetoric has reflected its state-centric and developing approach. As outlined by Zhang, China 'does not want to have a strong organization with mandatory powers that can force it to change beyond its ability and desire'. The principles that China has promoted in APEC are that China supports voluntary and unilateral efforts toward liberalization of trade and investment barriers (Economic Committee, 2010). China, like 
Japan, has insisted on maintaining APEC's informal nature, following ASEAN's consensus building and voluntary-based decision-making model as opposed to the U.S. proposal to legalize and institutionalize APEC as the WTO has been. In the 1993 APEC meeting, China's president Jiang Zemin noted that "APEC should be an open, flexible and pragmatic forum for economic cooperation and a consultation mechanism rather than a closed institutionalized economic bloc (1993)." China insisted on unilateralism and voluntarism as key norms of APEC for the following reasons: First, China worried that binding principles would threaten its economic sovereignty; second, China was aware that the U.S. intention to expand liberalization extensively might be detrimental to China's key industries; third, China wanted to prevent the U.S. from growing its dominance in APEC with a binding structure.

In addition, to balance the U.S. promotion of liberalization as key agenda for APEC, China insisted that the APEC agenda should balance between trade liberalization and economic cooperation. Since 1993, under the influence of the U.S., APEC's emphasis shifted from trade liberalization to economic and technology cooperation. However, China endeavored to promote technological and economic cooperation while maintaining its momentum for free trade. At the 1994 Bogor meeting, China proposed to hold a conference for ministers of science and technology.

With China's efforts as well as support from other developing countries, the 1996 Manila APEC meeting passed a "Declaration of a Framework of Principles for Economic Cooperation and Development" to encourage technological cooperation among APEC members. At the 1998 Kuala Lumpur APEC meeting, China further emphasized, 
"Promoting economic and technical cooperation among its members is a major task of APEC and a primary way to common development" (He, 2009). In the meantime, China set aside $\$ 10$ million to establish the China APEC Science and Technology Industry Cooperation Fund for promoting science and technology cooperation.

\subsubsection{Pursuing Balancing Alliances}

As reflected above, the U.S. was quite ambitious especially under Clinton's administration in institutionalizing APEC. However, U.S. ambition was counterbalanced by China, Japan, Australia and ASEAN. Pursuing balancing alliances has commonly been practiced by China and Japan in opposition to the U.S. through the course of APEC's development. Australia and ASEAN countries as other key actors of APEC play a significant role in China's, the U.S.'s, and Japan's strategy of pursuing balancing alliances.

When APEC was initiated in the first phase, ASEAN was reluctant to participate. Such reluctant participation can be perceived as bandwagoning action, which is a typical reaction by relatively small actors in the situation of changing coalitions and power equations. They joined the superior forces without opposing the establishment of APEC because they assume that asymmetrical interdependencies are less detrimental than an outright confrontation or exclusion from such an emerging regional institution. However, ASEAN, even though it consists of small and weak states in comparison with China, the U.S., and Japan is still an important actor in APEC and plays an essential role in China and Japan's balancing strategy.

China, the U.S. and Japan have different visions for APEC's scope of issues. While China and Japan desire a limited scoped of cooperation, the U.S., pressed by a variety of 
domestic interest groups, has pushed to include a number of other issues on APEC's agenda, ASEAN countries have also shown persistent wariness toward the U.S. tendency to expand the APEC agenda. For instance, Malaysia has resisted the U.S. effort to mobilize members of APEC to support the Millennium Round. Even in issue areas where the U.S. has succeeded in securing a formal liberalizing agreement, APEC members' opposition to U.S.' determination to operate the operating principle of reciprocity has stalled actual progress. For instance, in 1997 at the Vancouver conference, the U.S. led a effort to make the ninesector liberalization as a package including chemicals, energy-related equipment and services, environmental goods and services, forest products, medical equipment, telecommunications equipment, fish and fish products, toys, and gems and jewelry (Aggarwal, 2002). The U.S. promoted these nine sectors as a package to prevent member states from picking and choosing. But, in November 1998, Kuala Lumpur at the Sixth Leaders' Summit, Japan, lobbied the other Asian countries which were worried about moving forward with liberalization in their deteriorated economic state, and in alliance they refused to liberalize fishing and forestry products under the pressure of the U.S..

In terms of the cooperation agenda, the U.S. emphasis on liberalization has also been balanced by Japan, in alliance with other member states. Japan cautiously balanced the three goals of APEC, trade liberalization, facilitation, and cooperation. To achieve this purpose, Japan not only emphasized the importance of all of the three goals through its leaders' speeches and remarks at the APEC conference but also lobbied for allying other members to its vision of APEC. In 1989, Japan persuaded Australia not to highlight the importance of trade liberalization in the APEC meeting because it would scare away 
ASEAN countries (Funabashi, 1995). Later, Japan sided with developing countries, especially China and ASEAN, to emphasize economic cooperation and technology transfer in the APEC meetings to counterbalance the trade liberalization that U.S. promoted (Korhonen, 1998).

In addition, Japan worked together with ASEAN developing countries to set up consensus building, gradualism, and voluntarism in the APEC process. These rules render APEC a non-legalistic organization, which does not provide the U.S. and other developed countries with any legal power to enforce a free-trade agenda on developing economies. Although U.S. was able to push the Bogor timetable and the Osaka Action, there was no mechanism in APEC to enforce these agenda or punish non-compliance due to the successful balancing act by China and Japan.

As a later comer in APEC's establishment in comparison with the U.S. and Japan, pursuing balancing alliances with developing countries has been a key method of exercising institutional balancing for China. Binding itself with ASEAN developing countries has been one of the most important strategies that China has exercised in APEC. China has tried to make alliance with ASEAN countries by constructing and emphasizing its role as an important spokesman for developing countries. As mentioned above, China insisted that APEC should remain a flexible institution. Chinese leaders have repeatedly stressed that China, like the other developing countries, worried that the binding principle would threaten their sovereignty. Sharing the experience of being invaded by Japan and western powers, China was clearly aware of ASEAN countries' concern over sovereignty 
and interest in pursuing economic development without losing protection over strategically important sectors.

While the U.S. was able to push its liberalization agenda, its attempt to impose a political and security agenda on APEC was opposed by China in alliance with ASEAN countries. U.S. pushed the Bogor timetable to call for free trade and investment in the region by 2010 for developed countries and by 2020 for developing countries. However, China has repeatedly stressed that the norms of unilateralism and voluntarism should be adhered when discussing the achievement of the goal of liberalization because of the differences in the level of development within the region and the special conditions of the member states ${ }^{11}$.

\footnotetext{
${ }^{11}$ See President Jiang Zemin's key note speeches 1993,1994, 1995
} 


\section{CHAPTER VI FINDINGS AND CONCLUSION}

The contemporary regional system in Asia Pacific is characterized by three facts: First, China is steadily rising as maybe not the dominant super power, but the first-tier power that quests for stronger regional influence. Second, despite its relative decline in recent years, the U.S. is still the most powerful state in the globe. With the growing importance of the Asia Pacific, the U.S. has tried to ensure its sway in the region. Third, Japan, even though having declined as the dominant regional power after the 1997 financial crisis, still has devoted itself to strengthening its active role in regional affairs in Asia Pacific to meet domestic and foreign policy demands. Therefore, as revealed from these facts, the trilateral relation with each corner questing for more regional influence constitutes one of the most important features of the Asia Pacific that makes it a dynamic region with intense check and balance activity.

As demonstrated by this dissertation, hard balancing acts such as military coercion or economic sanction no longer have been the only tactics available to countries in order to achieve their purpose of balancing the other powers. Soft balancing, conducted in a comparatively unconfrontational and coercive manner, has been practiced by countries because in the present world hard balancing can be too costly to adopt, especially in less asymmetrical relations.

Within soft balancing, multilateral institutional balancing, has been increasingly conducted by countries for the following reasons: First, the trend of regional multilateralism is unavoidable since even though great powers have no interest in forming regional institutions at the beginning, small countries and second-tier powers have interests 
in using regional institutions as a way of counterbalancing the influence of dominant powers, as reflected in the formation of ASEAN and APEC. Second, once the trend of regional multilateralism started, it would be costly for any country that seeks regional power to reject the trend, as then it would be excluded from this multilateral framework in which common interests are addressed among members and alliance is more likely to be achieved among member states. Third, compared to bilateral negotiations, multilateral institutions provide states a more efficient way to pursue their goals and balance the other powers. Transaction costs can be significantly decreased if a country could shape the agenda, norms, and rules of the multilateral institution in its interest.

After historically reviewing China's, the U.S's., and Japan's changing policy towards regional institutions, this dissertation notes the following conditions under which states adopt an institutional balancing strategy:

When hard balancing is too costly to conduct, institutional balancing provides an efficient way to achieve states' balancing purpose. China, U.S., and Japan all have tried to avoid using hard balancing measure towards each other as exercising hard power is more likely to irritate the other power and lead to counterbalance reaction.

When states want to maintain or develop a positive relation with the other powers while protecting their own strategic interests. It is in the common interest of China, the U.S., and Japan to stimulate cooperation among themselves and maintain relatively benign relations. Therefore, for these three powers, regional and multilateral institutions provide an optimal way for them to balance the others through a multilateral framework in a more 
implicit way instead of through a bilateral way that may directly impair their bilateral relation.

When there are other players in regional institutions that are in a country's strategic interests and can be used as a medium to balance the other powers, states opt more for institutional balancing. For instance, in the case of APEC, ASEAN countries, even though they are not the strongest actors in terms of their military capacity and economic development, are very important actors to China, the U.S., and Japan, especially in the economic arena. All three countries desire to strengthen their relation with ASEAN countries for further access to the ASEAN market and ensure trade partnerships. In addition, ASEAN countries have been approached by both China and Japan for the purpose of making a balancing alliance against proposals introduced by developed nations such as the U.S.

This dissertation further develops the institutional balancing framework by discovering institutional balancing methods from analyzing China's, the U.S's., and Japan's participation in regional institutions. Membership is a key instrument provided by regional multilateral institutions: Countries can exclude a certain country from membership in order to keep that country outside the multilateral setting or include a certain country to strengthen their relation with the country and lobby for their support in the multilateral setting to balance targeted powers. Another important method noted in this dissertation is shaping an institution's norms, rules, and mechanisms. The promotion of certain norm, rules and mechanisms can be a more convenient approach for balancing purposes. Therefore, as revealed in the case study of APEC, all three powers have tried to promote 
certain norm, rules, and mechanisms in order to determine the structure of the framework within which all members have to abide by these norm, rules, and mechanisms. The third method, which is commonly practiced, is pursuing balancing alliances. This method is conducted with the same logic as making military balancing alliances. The balancer has to compete with the target of the balancing while forming a coalition within the institution.

The limitation of this dissertation rests in its scope of study. In this dissertation, only one case study, that of APEC, is included. Other regional institutions in which China, the U.S., and Japan are all involved, such as ARF and Six Party Talks, are not included in this dissertation. I acknowledge that even though APEC has been one of the most important and dynamic regional institutions with the longest history, it has its limitations in revealing all patterns of power interaction and practices of institutional balancing. There are two limitations that led to the exclusion of other regional institutions in this dissertation: time and research resources. In addition to the limitation of time, research resources regarding other regional institutions are inadequate. Unlike APEC, other regional institutions have not received adequate attention from governmental researchers and academic scholars especially in terms of forming focused study groups. Therefore, accumulating governmental and institutional documents is extremely hard and impossible in certain country's case for an in-depth historical analysis.

The future plan of this dissertation project is to challenge this limitation and try to expand this research to include another case study, one of ARF, by mainly researching institutional documents and using content analysis of public officials' related discourses. ARF, unlike APEC with an economic focus, has a security focus. In this way, comparison 
can be made between institutional balancing acts in an economic-focused institution and those in a security-focused institution and the findings discovered in this dissertation can be further conceptualized and developed. 


\section{REFERENCES}

Abbott, K.W., \& Snidal D. (2005). Why States Act Through Formal International Institutions. In Diehl. P.F. (Ed.), The Politics of Global Governance: International Organizations in an Interdependent World. (pp. 25-29). Boulder: Lynne Rienner.

Acharya, A. (1999). Realism, Institutionalism, and the Asian Economic Crisis. Contemporary Southeast Asia, 21(1), 1-29.

Acharya, A. (2003). Regional institutions and Asian security order: norms, power, and prospects for peaceful change. Asian security order: Instrumental and normative features, 210-240.

Acharya, A., \& Tan, S. S. (2006). Betwixt balance and community: America, ASEAN, and the security of Southeast Asia. International Relations of the Asia-Pacific, 6(1), 3759.

Aggarwal, V. (2000). Withering APEC? The Search for an Institutional Role. In Dosch, J. \& Mols, M. (Eds.), International Relations in the Asia-Pacific. New York: St. Martin's Press.

Ambrosio, T. (2008). Catching the 'Shanghai spirit': How the Shanghai Cooperation Organization promotes authoritarian norms in Central Asia. Europe-Asia Studies, 60(8), $1321-1344$.

APEC leaders back talks, but U.S. gets few victories. (1999). Wall Street Journal. Retrieved April 12, 2016, from http://search.proquest.com/docview/398753952.

Aris, S. (2009) The Shanghai Cooperation Organization: Tracking the 'three evils', a regional response to non-traditional security challenges or an anti-western bloc? EuropeAsia Studies, 61(3), 457-482.

ASEAN Regional Forum, -Chairman's Statement (2009). 16th ASEAN Regional Forum, Retrieved February 24, 2016, from http://www.mofa.go.jp/region/asiapaci/asean/conference/arf/state0907.pdf.

Ashizawa, P.K. (2004). Japan, the United States, and Multilateral Institution-Building in the Asia-Pacific. In Ellis S. K. \& Pempel, T. J. (Eds.), Beyond Bilateralism: U.S.-Japan Relations in the New Asia-Pacific. (pp. 248-271). California: Stanford University Press.

Association of Southeast Asian Nations, -ASEAN Regional Forum. Retrieved on February 4, 2016, from http://www.aseanregional forum.org/.

Association of Southeast Asian Nations, _East Asia Summit. Retrieved on March 7, 2016, from http://www.aseansec. org/aadcp/repsf/abouteastasiasummit.html. 
Astarita, C. (2008). China's Role in the Evolution of Southeast Asian Regional Organizations. China Perspectives, 3 (75), 78-86

Bennett, A. L, and James, K. O. (Eds.). (2002). International Organizations: Principles and Issues. Seventh New Jersey: Prentice Hall.

Bergstein, C. F, et al. (2008). China's Rise: Challenges and Opportunities. Washington DC: CSIS,

Betts, R. K. (1993). Wealth, Power and Instability: East Asia and the United States after the Cold War. International Security, 18 (3), 34-77.

Blank, S. (2008). Rethinking central Asian security. China and Eurasian Forum Quarterly, 6(2), 23-39.

Blum, R. M. (1982). Drawing the Line: The Origin of the American Containment Policy in East Asia. New York: Norton.

Boucoyannis, D. (2007). The International Wanderings of a Liberal Idea, or Why Liberals Can Learn to Stop Worrying and Love the Balance of Power. Perspectives on Politics, 5(4), 703-27.

Bush, G. (1991). Remarks by the President to the Asian Society. Washington, D.C.: The White House.

Bush.G. Sr. New World Order Speech. Retrieved from http://www.flixya.com/video/547984/George_Bush_Sr._New_World_Order_Speech (accessed on January 1, 2015).

Buzan, B. and Waver, O. (2003). Regions and Powers. New York: Cambridge University Press.

Buzan, B., Waver, O., and Wilde J. (1998). Security: a New Framework for Analysis. Boulder, London: Lynne Rienner Publishers. .

Calder, K. E. (1988). Japanese Foreign Economic Policy Formation: Explaining the Reactive State. World Politics, 40(4), 517-41.

Calder, K. E. (2004). Securing security through prosperity: the San Francisco System in comparative perspective. The Pacific Review, 17(1), 135-157.

Cha, V. D. (2016). Powerplay: The Origins of the American Alliance System in Asia: Princeton, New Jersey: Princeton University Press.

Chen, Q. (1992). Guanyu zai yatai digu jianli zhengzhi xin zhixu de tansuo [Seeking a new political order in the Asia-Pacific region]. Guoji shangbao, 1(5). 
Cheng, J.Y.S. (2001). Sino-ASEAN Relations in the Early Twenty-First Century. Contemporary Southeast Asia, 23(3). Retrieved on June 9, 2016, from https://www.questia.com/library/journal/1G1-82481112/sino-asean-relations-in-the-earlytwenty-first-century.

Christoffersen, G. (1996). China and the Asia-Pacific: Need for a Grand Strategy. Asian Survey, 36(11), 1067-1085. Retrieved from http://www.jstor.org/stable/2645636

Chung, C. P. (2011). Japan's involvement in Asia-centered regional forums in the context of relations with China and the United States. Asian Survey,51(3), 407-428.

Ciorciari, J. D. (2009). The balance of great-power influence in contemporary Southeast Asia. International relations of the Asia-Pacific, 9(1), 157-196.

Clarke, J. (1995). APEC as a semi-solution. Orbis 95, 39(1), 81-85.

Claude, I. L., Jr. (1962). Power and International Relations. New York: Random House.

Clinton, W. D. (1994). The Two Faces of National Interest. Baton Rouge: Louisiana State University Press.

Cohen, W. I. (2010). America's Response to China: A History of Sino-American Relations. Columbia University Press.

Cooney, K. (2007). Japan's Foreign Policy Since 1945. New York: M.E. Sharpe, Inc.,

Damiri, M. M. (2011). Cooperation within the ASEAN Plus Three Context: Incidental or Coincidence? Paper presented at the " $4^{\text {th }}$ International Conference on Southeast Asia (ICONSEA)", Kuala Lumpur, Malaysia 6-7 December 2011. Retrieved from http://www.academia.edu/1325179/Cooperation within the ASEAN_Plus Three Conte xt_Incidental_or_Coincidence.

Deng, Y. (1997). Japan in APEC: The Problematic Leadership Role, Asian Survey 37(4), 353-367.

Department of Defense. (1990). A Strategic Framework for the Asian Pacific Rim: Looking Toward the 21st Century. Washington, D.C.

Department of State. (2011). Remarks at the First Senior Officials Meeting (SOM) for the Asia Pacific Economic Cooperation (APEC) Forum. Retrieved on March $3^{\text {rd }}, 2016$, from http://www.state.gov/secretary/rm/2011/03/157940.htm.

$\mathrm{Du}, \mathrm{G}$. (1992). Jiji kaipi zhongri youhao guanxi de weilai [Work for brighter prospects in Sino-Japanese Rela- tions. Guoji shangbao, 3, 1-4.

Dosch, J. \& Mols, M. (2001). International relations in the asia-pacific: New patterns of power, interest, and Cooperation Jorn dosch \&nbsp;. New York: St. Martin's Press. 
Economic Committee. (2016). 2016 APEC economic policy report. Retrieved on June 10, 2016, from http://publications.apec.org/publication-detail.php?pub_id=1781.

Edstrom, B. (1999). Japan's Evolving Foreign Policy Doctrine: From Yoshida to Miyazawa. London: Macmillan Press.

Emmerson, D. K (2002). Appraising APEC: All Talk, No Walk? In Jurgen, R., Manske, E. \& Draguhn, W. (Eds.), Asia-Pacific Economic Cooperation (APEC): the first decade. New York: Routledge Curzon.

Envall, H. D. P. (2013). Japan's Strategic Challenges in Asia'. AIIA Policy Commentary, 15, 37-43.

Evans, P. (1996). The New Multilateralism in the Asia-Pacific and the Conditional Engagement of China. In Shinn, J (Ed.) Weaving the Net: Conditional Engagement with China. New York: Council on Foreign Relations.

Frankel, J. A., \& Kahler, M. (1993). Regionalism and rivalry: Japan and the United States in Pacific Asia. Chicago: University of Chicago Press.

Friedberg, A. L. (1993). Ripe for Rivalry: Prospects for Peace in Multipolar Asia. International Security 18 (1), 5-33.

Friedman, E., \& Selden, M. (1971). America's Asia: dissenting essays on Asian-American relations: Pantheon Books.

Fukushima, A. (1999). Japanese Foreign Policy: The Emerging Logic of Multilateralism. New York: St. Martin's Press.

Fukuyama, F. \& Kongdan, O. (1993). The U.S.-Japan Security Relationship after the Cold War. Santa Monica: Rand.

Funabashi. Y. (1995). Asia Pacific Fusion: Japan's Role in APEC. Washington D.C.: Institute for International Economics.

Gaddis, J. L. (1982). Strategies of Containment: A Critical Appraisal of Postwar American National Security Policy: Oxford University Press.

Gale, J. (1995). Agricultural trade liberalization and the APEC process. Journal of Northeast Asian Studies, 49-59.

Garnaut, R. (2004). A new open regionalism in the Asia Pacific. International conference on world economy, Colima, Mexico (Vol. 25).

Garofano, J. (2002). Power, institutions, and the ASEAN Regional Forum: a security community for Asia?. Asian survey, 42(3), 502-521. 
Geng, H. (1992). Multinational Coordination: Feasibility in Asia-Pacific. Contemporary International Relations, 2:1, 1-11.

Gill, B. (2004). Shanghai Five: An Attempt to Counter U.S. Influence in Asia?. Brooking. Retrieved on March $8^{\text {th }}$, 2016, from https://www.brookings.edu/opinions/shanghai-fivean-attempt-to-counter-u-s-influence-in-asia/.

Godwin, P. H. (2007). China as a major Asian power. In Goh, E. \& Simon, S.W. (Eds). China, the United States, and South-East Asia: Contending Perspectives on Politics, Security, and Economics (pp. 145-166). Routledge.

Goh, E. (2004). The ASEAN Regional Forum in United States East Asian strategy. The Pacific Review, 17(1).

Goh, E. (2008). Great powers and hierarchical order in Southeast Asia: analyzing regional security strategies. International Security, 32 (3), 113-157.

Goh, E. (2011). Institutions and the great power bargain in East Asia: ASEAN's limited 'brokerage' role. International Relations of the Asia-Pacific, 11, 373-401.

Goldstein, A. (2003). Balance-of-power politics: Consequences for Asian security order. Asian Security Order: Instrumental and Normative Features, 171-209.

Gong, Z. (1995). Development of the Asia-Pacific Economic Cooperation Organization and the Opening Up of China's Markets. Nankai jingli yanjiu [Nankai economic journal], 2,43 .

Greico,J. M. (1990) Cooperation Among Nations: Europe, America, and Non-Tariff Barriers to Trade. Ithaca: Cornell University Press.

Greico,J. M. (1993) Understanding the Problem of International Cooperation: The Limits of Neoliberal Institutionalism and the Future of Realist Theory. In Baldwin, D.A. (Ed). Neorealism and Neoliberalism: The Contemporary Debate. New York: Columbia University Press.

Guillain, R. (1969). The Japanese Challenge. London: Hamish Hamilton.

Guillain, R. (1970). A New Pacific Age. Pacific Community 1 (3), 487-97.

Guo, Z. (1995). The Political and Economic Situation China is Facing in the Asia-Pacific. Zhongguo waijiao (China's Foreign Affairs), Chinese People's University of Social Sciences Information Center.

Guo, Z. (1996). Asian-Pacific Region Remains Peaceful. Beijing Review, 6, 13.

Harding, H. (1984). China's foreign relations in the 1980s. New Haven: Yale University Press. 
Harris, S. (1995). Introduction: reading the Chinese tea leaves. In Harris. S. \& Klintworth, G. (Eds.) China as a Great Power in the Asia-Pacific Region: Myths, Realities and Challenges, Melbourne: Longmans.

Harris, S. (1997). The China-Japan Relationship AND Asia Pacific Regional Security .The Journal of East Asian Affairs, 11(1), 121-148. Retrieved on July 5 ${ }^{\text {th }}$, 2016, from http://www.jstor.org/stable/23255754.

He, K. (2006). Does ASEAN Matter? International Relations Theories, Institutional Realism, and ASEAN. Asian Security, 2(3), 189-214.

He, K. (2008). Institutional balancing and international relations theory: Economic interdependence and balance of power strategies in Southeast Asia. European Journal of International Relations, 14(3), 489-518.

He, K. (2012). Undermining adversaries: Unipolarity, threat perception, and negative balancing strategies after the Cold War. Security Studies, 21(2), 154-191.

He, K. and Feng, H. Y. (2008) If not soft balancing, then what? Reconsidering soft balancing and U.S. policy toward China. Security Studies 17(2), 363-395.

He, K. (2009). Institutional Balancing in the Asia Pacific: Economic Interdependence and China's Rise. London: Routledge.

He, K., \& Feng, H.Y. (2008). If not soft balancing, then what? Reconsidering soft balancing and US policy toward China. Security Studies, 17(2), 363-395.

Hemmer, C., \& Katzenstein, P. (2000). Collective Identities and the Origins of Multilateralism in Europe but not in Asia in the early Cold War. Paper presented at the 2000 Convention of the International Studies Association, Los Angeles.

Hogan, M. J. (1987). Redefining the Past: Essays in Diplomatic History in Honor of William Appleman Williams, Lloyd C. Gardner. The Journal of American History, 74(3), 1035-1037.

Horelick, A. (1974). The Soviet Union's Asian Collective Security Proposal: A Club in Search of Members. Pacific Affairs, 47(3), 269-285. Retrieved on December $26^{\text {th }}, 2015$, from http://www.jstor.org/stable/2755766 doi:1

Huisken, R., \& Thatcher, M. (Eds.). (2007). History as Policy: Framing the debate on the future of Australia's defence policy. ANU Press. Retrieved on March 3 ${ }^{\text {rd }}$, 2016, from http://www.jstor.org/stable/j.ctt24hbvw

Huntington, S. P. (1991). America's changing strategic interests. Survival, 33(1), 3-17. 
Ikenberry, G. J., \& Tsuchiyama, J. (2002). Between balance of power and community: the future of multilateral security cooperation in the Asia-Pacific. International Relations of the Asia-Pacific, 2(1), 69-94.

Inoguchi, T. (1993). Japan's Foreign Policy in an Era of Global Change. New York: St. Martin's Press.

Ippei Y. (2011). New IAP peer review process toward FTAAP. APEC Study Center Consortium Conference.

Iriye, A. (1967). Across the Pacific: an inner history of American-East Asian relations. Harcourt, Brace \& World.

Isaacs, H. R. (1958). Scratches on Our Minds: American Views of China and India. M. E. Sharpe.

Jervis, R. (1978). Cooperation Under the Security Dilemma. World Politics 30:167-214.

Jervis, R. (1983). Security Regimes. International Regimes, edited by Stephen D. Krasner. Ithaca: Cornell University Press.

Jervis, R. (1986). From Balance to Concert: A Study of International Security Cooperation". In Kenneth A. O. (Ed). Cooperation Under Anarchy. Princeton: Princeton University Press.

Jia, B. (1989). Sulian dui taipingyang jingji hezuo huiyi taidu de bianhua [The Soviet Union's change in attitude towards PECC]. Guoji wenti yanjiu, 2, 46-52.

Jiang Z. (1993). President Jiang Zemin's Keynote Speech at the 1994 Informal APEC Leadership Meeting available from http://www.fmprc.gov.cn.

Jiang Z. (1993). President Jiang Zemin's Keynote Speech.at the 1993 Informal APEC Leadership Meeting available from http://www.fmprc.gov.cn.

Jiang Z. (1995). President Jiang Zemin's Keynote Speech at the 1995 Informal APEC Leadership Meeting available from http://www.fmprc.gov.cn.

Jiang Z. (1996). President Jiang Zemin's Keynote Speech at the 1993 Informal APEC Leadership Meeting available from http://www.fmprc.gov.cn.

Jiang Z. (1997). President Jiang Zemin's Keynote Speech at the 1994 Informal APEC Leadership Meeting available from http://www.fmprc.gov.cn.

Jiang Z. (1998). President Jiang Zemin's Keynote Speech at the 1994 Informal APEC Leadership Meeting available from http://www.fmprc.gov.cn.

Jiang Z. (1999). President Jiang Zemin's Keynote Speech at the 1994 Informal APEC Leadership Meeting available from http://www.fmprc.gov.cn. 
Jiang, Z. (1986). Accelerating the Pace of Reform, Opening up, and Modernization and Achieving a Greater Victory of Socialism with Chinese Characteristics. Important Documents since the $14^{\text {th }}$ Congress of the CCP. Beijing: People Press.

Jiang, Z. (1986). Jiakuai gaige he xiandaihua jianshe bufa, duoqu you zhongguo tese shehuizhuyi shiye de gengda sheli.

Joseph M. G. (1996). State Interests and Institutional Rule Trajectories: A Neorealist Interpretation of the Maastricht Treaty and European Economic and Monetary Union, Security Studies 5, no. 3.

Joseph S. N. (1971). United States Policy Toward Regional Organization. In Tharp, P.A. (Eds). Regional International Organizations: Structures and Functions. New York: St. Martin's Press.

Kahler, M. (1991). Beyond the Cold War in the Pacific. IGCC Studies, 2, 1-12.

Kauppi, P. \& Viotti, M. (1999). International Relations Theory: Realism, Pluralism, Globalization and beyond. New York: Macmillan.

Kegley, J. \& Wittkopf, E. (2004). World Politics: Trends \& Transformation. Belmont: Wadsworth and Thomson Learning Inc.

Keith, R. (1992). China and Canada's "Pacific 2000 Strategy" Pacific Affairs, 65(3), 319333. doi:1. Retrieved on October $20^{\text {th }}$. 2016, from http://www.jstor.org/stable/2760066

Kennedy, D. E. (1965). The Security of Southern Asia: Praeger.

Kenneth, P. (2007). Japan Rising: the Resurgence of Japanese Power and Purpose. New York: Public Affairs.

Keohane, R. O. (2005). After hegemony: Cooperation and discord in the world political economy. Princeton University Press.

Keohane, Robert O and Nye, Joseph S. (1977). Power and Interdependence. Boston: Little Brown.

Keohane, R. O and Nye, J. S. (1987). "Power and Interdependence Revisited." International Organization. 41(4), 725-753.

Keohane, R. O and Nye, J. S. (1998). "Power and Interdependence in the Information Age. Foreign Affairs. 77 (5).

Keohane, R. O. (1989). International Institutions and State Power: Essays in International Relations Theory. Boulder: Westview Press. 
Khamchoo, C. (1989). Japan's Southeast Asian Policy in the Post-Vietnam Era (19751985). University Microfilms.

Kim, T. (2012). The ASEAN economic community and East Asian economic integration. Asian Responses to the Global Financial Crisis: The Impact of Regionalism and the Role of the G20, 135.

Kissinger, H. (1994).Diplomacy. New York: Simon \& Schuster.

Klintworth, G. (1995). China's Evolving Relationship with APEC. International Journal, 50(3), 488-515. doi:1. Retrieved from http://www.jstor.org/stable/40203019 doi:1

Korhonen, Pekka (1998). Japan and Asia-Pacific Integration. Pacific Romances 19681996, London and New York: Routledge.

Krauss E. S. (2000). Japan, the U.S., and the Emergence of Multilateralism in Asia. The Pacific Review, Vol. 13, No. 3.

Krauss, E.S. (2003). The U.S., Japan, and Trade Liberalization: From Bilateralism to Regional Multilateralism to Regionalism. The Pacific Review 16, no.3: 307-29.

Kumar, N. (2011). Financial Crisis and Regional Economic Cooperation in Asia-Pacific: Towards an Asian Economic Community? (No. WP/11/16). United Nations Economic and Social Commission for Asia and the Pacific (ESCAP).

Lanteigne, M. (2006-2007). "In Medias Res": The development of the Shanghai Cooperation. Pacific Affairs 79 (4),605-622.

Lasater, M. L. (1996). The new Pacific community: U.S. strategic options in Asia: Westview Press.

Lay, H, Y. (2006). Japan, ASEAN, and the Construction of an East Asian Community. Contemporary Southeast Asia 28, no.2. 259-75.

Leifer, M. (1996). The ASEAN Regional Forum. Adelphi Paper, no. 302.

Leifer, M. (1999). The ASEAN Peace Process: A Category Mistake. The Pacific Review 12, no.1: 25-39.

Lipson, C. (1984). International cooperation in economic and security affairs. World Politics, 37(01), 1-23.

Little, Richard. (2007). The Balance of Power in International Relations: Metaphors, Myths and Models. Cambridge University Press.

Liu, F. (2007) Eluosi zai Zhongya: Zhengze de Yanbian (Russia in Central Asia: Evolution of policies). Guoji Zhengzhi Yanjiu (Studies of International Politics) 2007(2): 150-166. 
Lu, J. (1996). China's position toward APEC. The World Economy and China, 3(43), 5.

Ma, C. and Duan J. (1988). Taipingyang shidai: Zhongguo mianlin de tiaozhan yu jueze [The Asia-Pacific era: China confronts challenges and choices]. Harbin: Heilongjiang renmin chubanshe.

Marketos, T.N. (2009) China's Energy Geopolitics: The Shanghai Cooperation Organization and Central Asia. New York: Routledge.

Masahiko E. and Masaharu H. (1987). China's Open Door Policy and its Implication for Asia-Pacific Countries Towards the Year 2000. China Newsletter, 66, 2-7.

Mayumi, I (1993). Japanese Perceptions of the United States. Asian Survey 33, no. 12. 1122-35.

McDougall, D. (2012). Responses to 'Rising China in the East Asian Region: soft balancing with accommodation. Journal of Contemporary China, 21(73), 1-17.

Mearsheimer, J. J. (1994). The False Promise of International Institutions. International Security. 19.(3), 5-49.

Mearsheimer, J. J. (2003). The Tragedy of Great Power Politics. Reprint. New York \& London: W. W. Norton \& Company.

Michael, G. (2001). Japan's Reluctant Realism. New York: Palgrave.

Midford P. (2000). Japan's Leadership Role in East Asian Security Multilateralism: the Nakayama Proposal and the Logic of Reassurance. The Pacific Review, 13(3), 367-397.

Mingst, K. A. (2004). Essential of International Relations. 3rd Ed. New York and London: Norton \& Company.

Ministry of Foreign Affairs of Japan (1989). Japan's Diplomatic Blue Book.

Ministry of Foreign Affairs of Japan (1993). Japan's Diplomatic Blue Book.

Ministry of Foreign Affairs of Japan (1994). Japan's Diplomatic Blue Book.

Ministry of Foreign Affairs of Japan (1995). Japan's Diplomatic Blue Book.

Ministry of Foreign Affairs of Japan (1996). Japan's Diplomatic Blue Book.

Ministry of Foreign Affairs of Japan (1997). Japan's Diplomatic Blue Book.

Ministry of Foreign Affairs of Japan (1998). Japan's Diplomatic Blue Book.

Ministry of Foreign Affairs of Japan (1999). Japan's Diplomatic Blue Book. 
Ministry of Foreign Affairs of Japan (2000). Japan's Diplomatic Blue Book.

Ministry of Foreign Affairs of Japan (2010). Japan's Diplomatic Blue Book.

Ministry of Foreign Affairs of the People's Republic of China. (November 17, 2000). Proactive Policies by China in Response to the Asian Financial Crisis. Retrieved on April, $8^{\text {th }}$, 2016, from http://www.fmprc.gov.cn/eng/ziliao/3602/3604/t18037.htm.

Morgenthau. H. J. (1973). Politics Among Nations: The Struggle for Power and Peace. New York: Alfred A. Knopf, Inc.

Morrison, C. E., \& Pedrosa, E. (Eds.). (2007). An APEC trade agenda?: the political economy of a free trade area of the Asia-Pacific. Institute of Southeast Asian Studies.

Morrison, C., \& Aggarwal, V. (2000). APEC as an International Institution. Yamazawa, Ippei (et. al). Asia Pacific Economic Cooperation (APEC), Challenges and tasks for the twenty first century. Routledge, London.

Nagashima, D. K. (2007). Waves of Japanese Foreign Policy: From Constrained Bilateralism and Political Multilateralism to Reinforced Bilateralism in the Post-Cold War Era.

Nagesh, N. (1996). Japan's economic diplomacy in Southeast Asia. Lancers Books.

Nair, D. (2009). Regionalism in the Asia Pacific/East Asia: a frustrated regionalism?. Contemporary Southeast Asia: A Journal of International and Strategic Affairs, 31(1), 110-142.

New dynamics in U.S. global trade strategy? A reinvigorated japan and the trans-pacific Partnership Roundtable. (2013).

Nihon Keizai Kenkyu Center (1995). Kaiho [Center Report], 1 December.

Niou, E. M. S \& Ordeshook, P. C.(1986). A Theory of the Balance of Power in International System. Journal of Conflict Resolution, 30.4, 685.

Office of the U.S. Trade Representative. (2010). Positive Outcome from Fourth Round of Trans-Pacific Partnership Negotiations, Retrieved on May $3^{\text {rd }}, 2015$, from https://ustr.gov/about-us/policy-offices/press-office/pressreleases/2010/december/positive-outcome-fourth-round-trans-pacific-partn..

Okano,H, M. (2007). Japan's Economic Diplomacy towards China: The Lure of Business and the Burden of History. Netherlands Institute of International Relations.

Organization as a Security Community. Pacific Affairs 79(4), 605-622. 
Organization in Sino-Russo relations. Heping yu Fazhan (Peace and Development) 2010(2): 37-42.

Ovendale, R. B. The United States and the Cold War in Southeast Asia, 1949-50. International Affairs, 447-464.

Pan, G. and Wang, Y. D. (2001). Lengzhanhou Zhongguo Waijiao Xinzhanlue de si kao, (Thoughts on China's post-cold war new foreign policy strategy). Guoji Zhengzhi Yanjiu (Studies of International Politics), 1 (6).

Pape, R. (2005). Soft balancing against the united states. International Security 30, 1, 7-45.

Pascha, W. (2007). The Role of Regional Financial Arrangements and Monetary Integration in East Asia and Europe in Relations with the United States. The Pacific Review, 20(3), 423-446.

Park, J. (1993). Impact of China's Open-Door Policy on Pacific Rim Trade and Investment. Business Economics, 28(4), 51-56. Retrieved on February $3^{\text {rd }}, 2015$, from http://www.jstor.org/stable/23486252

Patrick M.M. (1997). Regional Security Complexes and Regional Orders. In David A. L and Patrick M. M. (Eds.), Regional Orders (University Park: Penn State University Press.

Paul, M. (2000). Japan's Leadership Role in East Asian Security Multilateralism: The Nakayama Proposal and the Logic of Reassurance. The Pacific Review 13, no. 3:367-97.

Paul, R. A. (2005). Soft balancing in the age of U.S. primacy. International Security 30, 1, 46-71.

Paul, T.V. (2004) The Enduring Axioms of Balance of Power Theory. In Paul, T. V., Wirtz, James \& Fortmann, M. (Eds.) Balance of Power: Theory and Practice in the 21st Century ( pp. 1-28). Stanford, CA: Stanford University Press.

Paul, T.V. (2005). Soft Balancing in the Age of US Primacy, International Security

Pauly, L. W., \& Grieco, J. M. (1991). Cooperation among Nations Europe, America, and Non-Tariff Barriers to Trade.

Pempel, T. J. (2010). Soft balancing, hedging, and institutional darwinism: The economic-security nexus and East Asian regionalism. Journal of East Asian Studies, 10(02), 209-238.

Percival, B. (2006). Japan-Southeast Asia Relations: Playing Catch-up with China. Comparative Connections, 8(3), 2-4.

Petri, P. A. (2000). 4 APEC and the millennium round. Asia Pacific Economic Cooperation (APEC): challenges and tasks for the twenty-first century, 98. 
Pratt, J. W. (1932). The "Large Policy" of 1898. The Mississippi Valley Historical Review, 19(2), 219-242.

Pressello, A. (2014). The Fukuda Doctrine and Japan's Role in Shaping Post-Vietnam War Southeast Asia. Japanese Studies, 34(1), 37-59.

Ravenhill, J. (2001). APEC and the construction of Pacific Rim regionalism. Cambridge University Press.

Robyn, L. (2002). Japan Re-Engages Southeast Asia. Far Easter Economic Review, January 24: 26.

Ross, R. (2004). Bipolarity and Balancing in East Asia. Stanford University Press.

Rother, S. (2012). Wendt meets East: ASEAN cultures of conflict and cooperation. Cooperation and Conflict, 47(1), 49-67.

Saito, J. (1999). Tokyo, Washington disagreement smolders at APEC. Asahi News enews, Retrieved on September $1^{\text {st }}, 2015$, from www.asahi.com/english/enews/enews.html.

Sakakibara, E., \& Yamakawa, S. (2003). Regional Integration in East Asia: Challenges and Opportunities-Part II: Trade, Finance, and Integration.

Saltzman, I. Z. (2012). Soft balancing as foreign policy: assessing American strategy toward Japan in the interwar period. Foreign Policy Analysis, 8(2), 131-150.

Samuel K. (1992). China as a Regional Power. Current History, 247-52.

Schweller, R.L. and Priess, D. (1997). A Tale of Two Realisms: Expanding the Institutions Debate. Mershon International Studies Review, 41 (1).

Scollay, R. (2011). Evolution of the Asia-Pacific Trade Architecture: Stocktake and Future Outlook. In Aggarwal, Vinod y Feinberg, Richard (et. al). APEC Study Center Consortium Conference (pp. 145-161).

Sekai (1967). Trends in Japan: What Miki’s Diplomacy Aims. Paper presented at Europe, East Asia and APEC conference, 28-29 August, Australian National University.

Sheldon, S. (1999). Multilateralism and Japan's Security Policy. The Korean Journal of Defense Analysis XI. No. 2: 79-96

Shi, X. (1990). Perspectives of the Strategic Situation in the Asian-Pacific Region in the 1990s. International Strategic Studies, 1, 8-10.

Shibusawa, M. (1984). Japan and the Asian Pacific Region. St Martin's Press. 
Shirk, S. L. (1994). Chinese views on Asia-Pacific regional security cooperation. Seattle, WA: National Bureau of Asian Research.

Simon, S.W. (1993). U.S. Strategy and Southeast Asian Security: Issues of Compatibility. Contemporary Southeast Asia, 14(4), 301-313.

Simone, V. (2001). The Asian Pacific: Political and economic development in a global context. Pearson College Division.

Singer, D. J. \& Small, M. (1967). Formal Alliances, 1815-1939. Journal of Peace Research. Vol I, pp. 1-32.

Smith, A. (2006). Japan's Relations with Southeast Asia: The Strong Silent Type. Japan in a Dynamic Asia: Coping with the New Security Challenges. Lanham: Lexington Books, 179-198.

Smith, G. J. (1997). Multilateralism and regional security in Asia: the ASEAN Regional Forum (ARF) and APEC's geopolitical value: Center for International Affairs, Harvard University.

Sneider, D. (2011). The new Asianism: Japanese foreign policy under the Democratic Party of Japan. Asia Policy, 12(1), 99-129.

Snidal, D. (1991). Relative Gains and the Pattern of International Cooperation. American Political Science Review, 85(3), 701-726.

Song, W. (2013). Feeling safe, being strong: China's strategy of soft balancing through the shanghai cooperation organization. International Politics, 50(5), 664-685. doi:10.1057/ip.2013.21

Stubbs, R. (2002). ASEAN plus three: emerging East Asian regionalism? Asian Survey, 42(3), 440-455.

Sudo, S. (2009). Japan's ASEAN Policy: Reactive or Proactive in the Face of a Rising China in East Asia? Asian Perspective, 137-158.

Sudo, S. (2013). The international relations of Japan and South East Asia: Forging a new regionalism. Routledge.

Suetsugu T. and Oyama H. (2005). East Asia Meet Gives Warm Fuzzies, but Function Vague. Daily Yomiuri.

Takashi, I. (1993). Japan's Foreign Policy in an Era of Global Change. New York: St. Martin's Press.

Takashi, T. (1998). The Origins of Japan's APEC policy: Foreign Minister Takeo Miki's Asia-Pacific policy and Current Implications. The Pacific Review, 11:3, 337-363. 
Takenaka, Y. (1994). A Collapse in Centrist Politics: Takeo Miki's Diplomatic and Defense Stances. Annual Series of Study on Modern Japan. No. 16. Tokyo: Yamakawa Shuppansha.

Takeshi, Y. (2005). Japan's Changing Conception of the ASEAN Regional Forum: From an Optimistic Liberal to a Pessimistic Realistic Perspective. The Pacific Review 18(4), 46397.

Tan, S. S. (2015). Asian Multilateralism in the Age of Japan's 'New Normal': Perils and Prospects. Japanese Journal of Political Science, 16(03), 296-314.

Tao, W. S, Du, R Q, \& Wang, Q. (Ed.). (2003). China-U.S. Relation and East Asia International Structure [Zhong Mei Guan Xi Yu Dong Ya Guo Ji Ge Ju]. Beijing: China Social Science Press [Zhong Guo She Hui Ke Xue Chu Ban She].

The ASEAN Secretariat. (2009). Roadmap for an ASEAN Community 2009-2015. Jakarta: ASEAN Secretariat.

The National Bureau of Asian Research. (2013). New Dynamics in U.S. Global Trade Strategy? A Reinvigorated Japan and the Trans-Pacific Partnership, http://www.nbr.org/research/activity.aspx?id=359 (accessed April, 2015).

Tow, W. T. (1993). Contending Security Approaches in the Asia-Pacific Region. Security Studies 3, no. 1: 75-116.

Tow, W. T. (2001). Asia-Pacific Strategic Relations: Seeking Convergent Security. Cambridge University Press.

Treadgold, D. W. (1980). The United States and East Asia: A Theme with Variations. Pacific Historical Review, 49(1), 1-27.

U.S. Consulate-General. (1991). Prospects for New Asian-Pacific Political Order. Foreign Broadcast Information Service, Hong Kong, JPRS-CAR-91- 030, 3.

U.S. Department of Defense. (1990). A Strategic Framework for the Asian Pacific Rim: Looking Forward to the $21^{\text {st }}$ Century. Washington, D.C.: Department of Defense.

U.S. Department of Defense. (1992). A Strategic Framework for the Asian Pacific Rim. Washington, D.C.: Department of Defense.

U.S. Department of Defense. (1995). United States Strategy for the East Asia-Pacific Region, Washington, D.C.: Department of Defense.

U.S. Department of Defense. (1998). The United States Strategic Strategy for the East Asia Pacific Region. Washington, D.C.: Department of Defense. 
United States Congress House Committee on Foreign Affairs Subcommittee on Asia, the Pacific, and the Global Environment. (2010). Renewed engagement : U.S. policy toward Pacific island nations : hearing before the Subcommittee on Asia, the Pacific, and the Global Environment of the Committee on Foreign Affairs, House of Representatives, One Hundred Eleventh Congress, second session, September 29, 2010. Washington : U.S. G.P.O.

United States Congress House Committee on Foreign Affairs. (1993). Asia Pacific Economic Cooperation (APEC) and U.S. policy toward Asia: hearing before the Committee on Foreign Affairs, House of Representatives, One Hundred Third Congress, first session, November 15, 1993. Washington : U.S. G.P.O.

Van, H. P. (1998). China and the Third World: Patterns of Engagement and Indifference. In Samuel, K. S. (Ed.) China and the World: Chinese Foreign Policy Faces the New Millennium (pp. 151-70) .Boulder, Colo: Westview Press.

Waltz, K. N. (2010). Theory of international politics. Waveland Press.

Waltz, K. N. (1979). Theory of International Politics. Reading: Addison-Wesley.

Wang, J. (1998). Chinese Perspectives on Multilateral Security Cooperation. Asian Perspective, 22(3), 103-132. Retrieved on May $1^{\text {st }}$ 2015, from http://www.jstor.org/stable/42704183.

Warren, C. (1993). American Foreign Policy: The Strategic Priorities. Paper presented at the Senate Foreign Relations Committee.

Warren, C. (1998). In the Stream of History-Shaping Foreign Policy for a New Era. Stanford, California: Stanford University Press.

Wesley, M. (Eds.) (2003). The Regional Organizations of the Asia- Pacific: Exploring Institutional Change. New York: Palgrave Macmillan.

Wheeler, G. E. (1957). The United States Navy and the Japanese "Enemy": 1919-1931. Military Affairs, 21(2), 61-74.

Whelan, R. (1990). Drawing the Line: The Korean War 1950-53 Boston: Little Brown.

Whelan. G. F. (2004). Hume and Machiavelli: Political Realism and Liberal Thought. Lanham: Lexington Books.

Wight, M. (1966). The Balance of Power. In Butterfield, H. \& Wight, M. (Eds.). Diplomatic Investigations: Essays in the Theory of International Politics. London: Allen and Unwin. 
$\mathrm{Wu}, \mathrm{X}$. (2009). Chinese perspectives on building an East Asian community in the twentyfirst century. Asia's New Multilateralism: Cooperation, Competition, and the Search for Community, 55-77.

Yamazawa, I. (2012). APEC: New agenda in its third decade. Institute of Southeast Asian Studies.

Yan, X. (1994). China's Regional Policy. Association of Chinese Political Science (ACPS) annual meeting, Honolulu, 2.

Ye, S. (2010). China's Regional Policy in East Asia and Its Characteristics. China Policy Institute Discussion Paper, 66, 1-31.

Yoshimatsu, H. (2007). Japan's economic diplomacy towards East Asia: fragmented realism and naive liberalism. (RSIS Working Paper, No. 146). Singapore: Nanyang Technological University.

Young, O. (1991). Political Leadership and Regime Formation: On the Development of Institutions in International Society. International Organization. 45(3), 281-308.

Yutaka, K. (2003). Japanese Foreign Policy at the Crossroads: Challenges and Options for the Twenty-First Century. Washington D.C.: Brookings Institution Press.

Zhang X, Z. (1999) "Zhongguo tong Dongmeng de mulin huxin huoban guanxi," (The Good Neighborly, Mutual Trusting and Partnership Relations between China and ASEAN,") Dangdai Yazhou (Contemporary Asia), no. 2.

Zhang, Y., \& Austin, G. (Eds.). (2013). Power and Responsibility in Chinese Foreign Policy. ANU Press. Retrieved from http://www.jstor.org/stable/j.ctt5vj73b

Zhao, H. (2010). Zhong E Guanxi zhong de Shanghai Hezuo Zuzhi (Shanghai Cooperation Zheng, Y. (Ed.) (2007). Zhong Mei E zai Zhongya: Hezuo yu Jingzheng: 1991-2007 (Cooperation and Competition: China, Russia and the U.S. in Central Asia). Beijing: Social Sciences Academic Press. 
VITA

\title{
YUANYUAN FANG
}

\author{
Languages: Chinese, English, Japanese
}

$2005-2009$

B.A., English Linguistics and Literature

Beijing Language and Culture University

$2007-2008$

Exchange Student

Curtin University

$2009-2011$

M.A., Asian Studies

Florida International University

$2010-2010$

Summer Study Abroad Program

Ritsumeikan University

$2011-2017$

Doctoral Candidate

Florida International University

Adjunct Instructor: INR3703 International Political Economy (Fall2014, Summer 2014, Spring 2014, Fall 2013): explores the important concepts, theories, and contending approaches used in the study of international political economy.

Teaching Assistant: International Political Economy; Political Economy of China; Foreign Policy of China; Introduction to International Relations; Contemporary Dynamic of International Relations (graduate course).

\section{ACADEMIC CONFERENCES AND PUBLICATIONS}

Contest for Supremacy: the Struggle for Leadership in the Asia Pacific between China and the U.S., accepted and will be presented at International Studies Association (ISA) Annual Convention, Baltimore, 2017.

$>$ Balance of Power in Regional Institutional Framework: Reassessment of the U.S.-ChinaJapan Trilateral Relations, presented at International Studies Association (ISA) Annual Convention, Atlanta, 2016.

Reassessment of U.S.-China Relations: a Regional Institution-Based Analysis, presented at 2015 ISA West Annual Conference. 
$>$ U.S. and China's Foreign Policy towards Asia-Pacific Economic Cooperation, presented at Regional Studies Association, Melbourne Australia, 2015.

> U.S. Asia Pacific Rebalancing and Asia Pacific Regional Institution, presented at Political Science and International Relations Community Annual Conference, Beijing, 2015.

$>$ Between Poverty \& Prosperity: China's dependent development and the "Middle-Income Trap”, Co-authors: Jin (Julie) Zeng \& Yuanyuan Fang, published in The Third World Quarterly. Vol 35 (1) 2014.

$>$ U.S. and China's Economic Diplomacy Rivalry in Southeast Asia, presented at 2014 FPSA Annual Conference.

> Middle-Income Trap: a Challenge Facing the Chinese Leadership, Co-authors: Professor Julie Zeng, Yuanyuan Fang, Presented at 2013 MPSA Annual Conference, 2013 ISA Northeast Annual Conference, and ACPS 2012 Annual Conference.

$>$ China's Exercise of Soft Power in the 21st century: a Comparative Study, Presented at 2013 ISA Northeast Annual Conference, 2013 Chinese Studies Conference at Utah Valley University.

$>$ U.S. Foreign Policy and U.S. INGO, Presented at 2012 FPSA Annual Conference.

$>$ Education on Emotion Attitude is the Key of Successful Teaching, published in "Study Monthly", Vol. 9, 2008.

$>$ Social Development Needs to Improve English Writing-Reflects on English Writing Teaching from Its Current Practice, published in "Education Science \& Culture Magazine", Vol. 10, 2008. 